Portland State University

PDXScholar

1986

\title{
The structural controls of the Vale Rhinehart Buttes complex, Vale KGRA, Malheur County, Oregon
}

John Timothy Doerr

Portland State University

Follow this and additional works at: https://pdxscholar.library.pdx.edu/open_access_etds

Part of the Geology Commons, and the Tectonics and Structure Commons Let us know how access to this document benefits you.

Recommended Citation

Doerr, John Timothy, "The structural controls of the Vale Rhinehart Buttes complex, Vale KGRA, Malheur County, Oregon" (1986). Dissertations and Theses. Paper 3585.

https://doi.org/10.15760/etd.5468

This Thesis is brought to you for free and open access. It has been accepted for inclusion in Dissertations and Theses by an authorized administrator of PDXScholar. Please contact us if we can make this document more accessible: pdxscholar@pdx.edu. 
ABSTRACT OF THE THESIS OF John Timothy Doerr for the Master of Science in Geology presented November 24, 1986.

Title: The Structural Controls of the Vale Rhinehart Buttes Complex, Vale KGRA, Malheur County, Oregon.

APPROVED BY MEMBERS OF THE THESIS COMMITTEE:

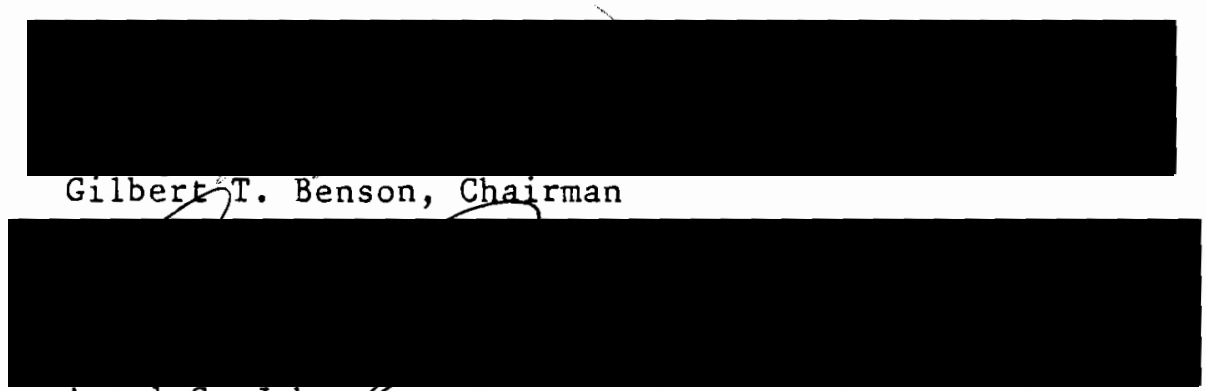

Anse 1 G. Johnsern

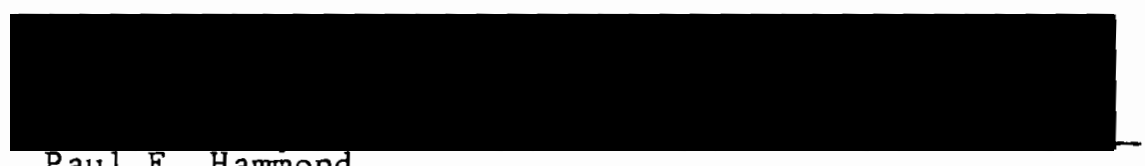

Paul E. Hammond

The Vale KGRA is characterized by high heat flow, two to five times higher than the worldwide average, and by numerous hot springs. The hot springs are aligned along faults. This phenomena is typical of a Basin and Range type geothermal system. The hot geothermal fluids migrate upward along the more permeable, fault planes.

The rocks exposed in the Vale area are the Pliocene Chalk Butte formation and the Pleistocene beds of Captain Keeney Pass. Both units are composed of volcaniclastic siltstones, sandstones and conglomerates. The units are differentiated by color, texture and degree of lithification. About 200 meters of the Chalk Butte formation and 100 meters of the beds of Captain Keeney Pass are exposed in the 
area. Silicification is wide spread in the rocks of the Chalk Butte formation.

The structure of the Vale area is dominated by north to northwest trending faults. To the north are the Willow Creek fault and the Bully Creek fault. These two faults have been identified north of the study area and continue through the area. The main faults in the study area are the north trending Rhinehart fault, the northwest trending Willow Creek Fault, and two unnamed northwest trending faults. One of the unnamed faults is located east of Vale Butte and the other is located in the soutliwest portion of the study area.

The central portion of the Vale horst, the area of Vale Butte and Rhinehart Buttes, contains the Rhinehart fault and the Willow Creek fault and is characterized by many small normal faults. These small faults occur as either en echelon or horst and grabens and are oblique to the main trends in the area.

Rhinehart Buttes is an erosionally resistant fossil hot spring, cored by a silicified zone centered on the north trending Rhinehart fault. Many of the ridges which extend from Rhinehart Buttes are also cored by silicified zones. The silicified rocks are more resistant than the country rocks and the silicified areas adjoining the faults tend to form linear ridges. Vale Butte consists of Chalk Butte formation siltstones interbedded with silicified conglomerates which protect the siltstones from erosion.

The extent and degree of silicification is controlled by both the structure and rock type. The areas of the highest degree of 
silicification and secondary mineralization of quartz, calcite and selenite occur at the intersection of faults. The intensity of silicification decreases away from fault intersections. This decrease occurs both along the strike of the fault and perpendicular to the strike. The areal extent of silicification is highest in open framework, clast supported conglomerates. Silicification deceases according to permeability. Coarse grained clast supported sandstones show somewhat lesser silicification while in siltstones the silicification is limited to areas immediately adjoining the faults intersections.

Gravity and magnetic modeling agrees with the interpretation of the major structures of the area. The gravity models depict an upper layer of volcaniclastic sediments of low density, $2.1 \mathrm{~g} / \mathrm{cm}$ overlying the subsurface Grassy Mountain Basalt at a depth of about 200 meters, which has been offset by a series of small normal faults. A number of these faults appear to have offset the Grassy Mountain Basalt. The locations of these faults found by gravity modeling agree with faults mapped in the field.

Between the north side of Rhinehart Buttes and the Malhuer River, a local hot water aquifer is contained in the recent sediments. The temperature of the water in the aquifer increases toward the southeast. The structure controlling the entrance of geothermal fluids into the acquifer is believed to be a silicified fault trending west northwest at the north end of Rhinehart Butte. 
THE STRUCTURAL CONTROLS OF THE VALE RHINEHART BUTTES COMPLEX, VALE KGRA, MALHEUR COUNTY, OREGON

by

JOHN TIMOTHY DOERR

A thesis submitted in partial fulfillment of the requirements for the degree of

\author{
MASTER OF SCIENCE \\ in \\ GEOLOGY
}

Portland State University

1986 
TO THE OFFICE OF GRADUATE STUDIES AND RESEARCH: The members of the Committee approve the thesis of John Timothy
Doerr presented November 24,1986 .

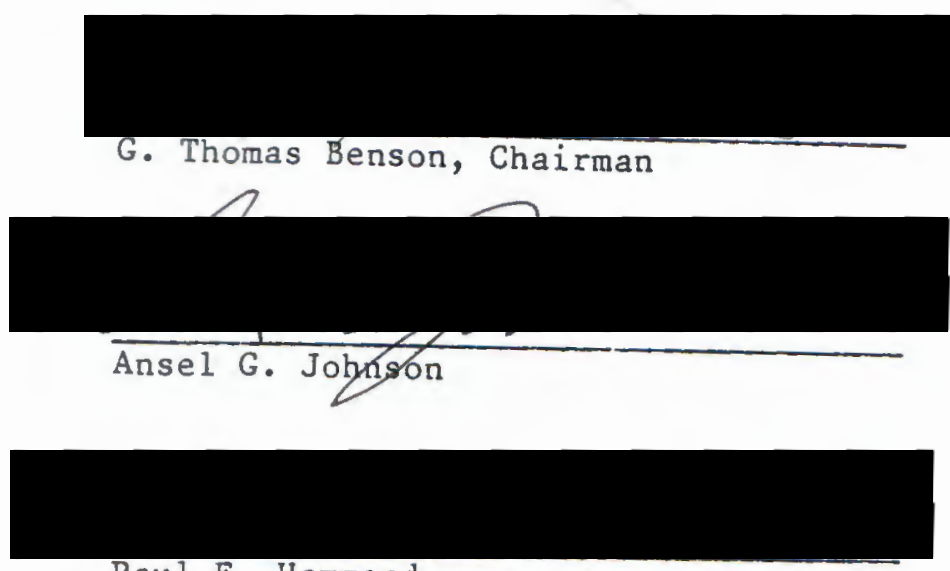

Paul E. Hammond

APPROVED:

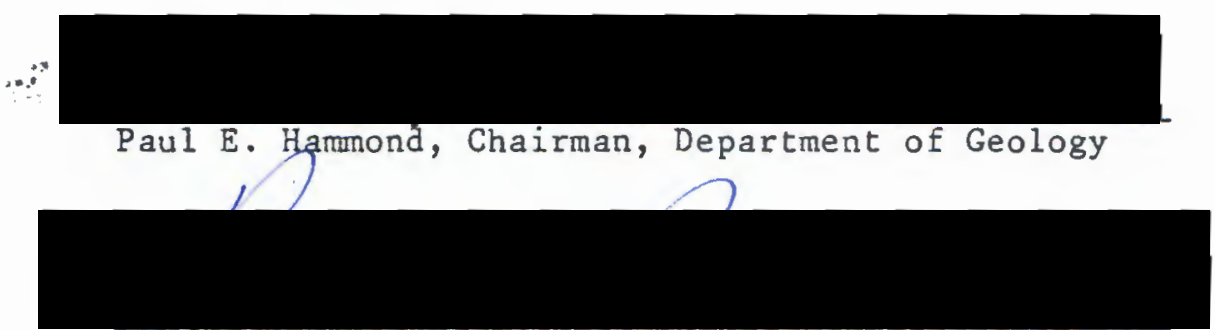

Bernard Ross, Dean of Graduate Studies and Research 


\section{ACKNOWLEDGEMENTS}

I would like to acknowledge and thank those who have provided me fwith the support and guidence to complete this study. First I would like to thank the members of Renewable Energy Inc. who have allowed me to use the data. In particular, I would like to thank Mr. Robert 0 . Walston, the project manager, who aided me in doing so many of the tasks in this project. I would like to thank the members of iny advisory comittee, Dr. Gilbert T. Benson, Dr. Ansel G. Johnson, and Dr. Paul E. Hammond, for their efforts, advice, and support. I also would like to thank Cindy Stine for her help with the more mundane and unrewarding tasks in preparing the manuscript. Lastly and nost importantly I would like to thank my wife, Sharon, for her support, both financial and emotional without which I never would have finished this project. 


\section{CHAPTER}

I INTRODUCTION $\ldots \ldots \ldots \ldots \ldots \ldots \ldots \ldots \ldots \ldots \ldots \ldots \ldots \ldots$

Purpose of study..................... 1

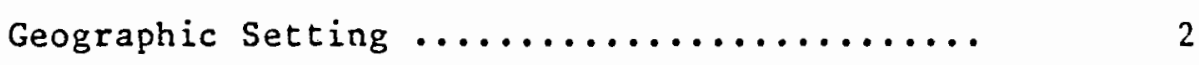

Previous Work $\ldots \ldots \ldots \ldots \ldots \ldots \ldots \ldots \ldots \ldots \ldots$

II REGIONAL GEOLOGY $\ldots \ldots \ldots \ldots \ldots \ldots \ldots \ldots \ldots \ldots \ldots$

Regional Geologic History .............. 7

Regional Structural Geology ............. 12

II GEOLOGY OF THE VALE AREA ................. 14

Stratigraphy of the vale Area ........... 14

Chalk Butte Formation ................ 14

The Rocks of Captain Keeney Pass............ 24

Structural Geology of the Vale Area ........ 25

The Geothermal system at vale ........... 32

silicification in the vale Area ........... 33

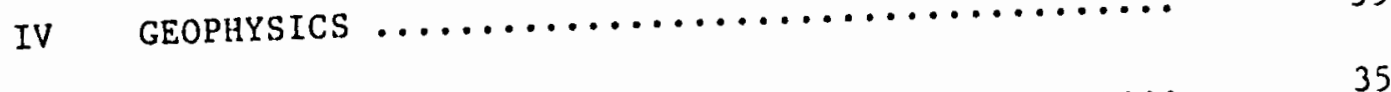

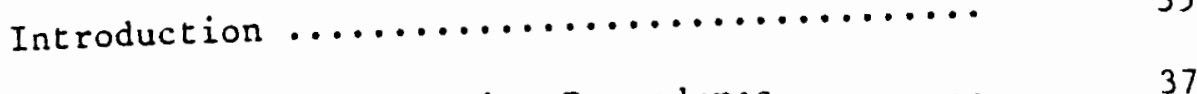

Survey and Data Reduction Procedures ........

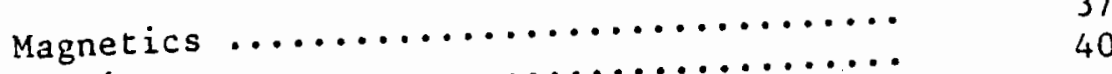

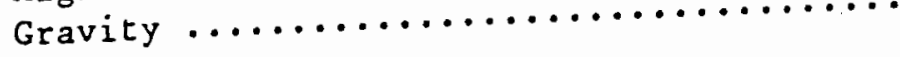

Gravity Modeling 
A Line $\ldots \ldots \ldots \ldots \ldots \ldots \ldots \ldots \ldots \ldots \ldots \ldots \ldots . \ldots \ldots$

B Line ....................... 57

Interpretation $\ldots \ldots \ldots \ldots \ldots \ldots \ldots \ldots \ldots \ldots \ldots$

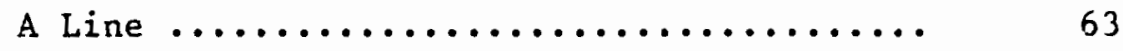

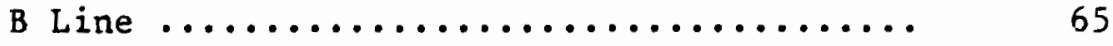

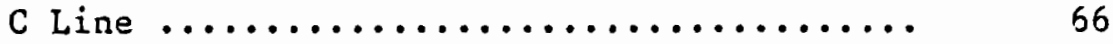

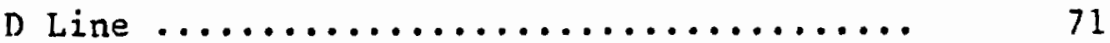

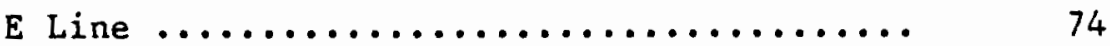

F Line $\ldots \ldots \ldots \ldots \ldots \ldots \ldots \ldots \ldots \ldots \ldots \ldots . \ldots \ldots$

Magnetic Modeling and Interpretation ........ 83

B Line $\ldots \ldots \ldots \ldots \ldots \ldots \ldots \ldots \ldots \ldots \ldots . \ldots \ldots . \ldots \ldots$

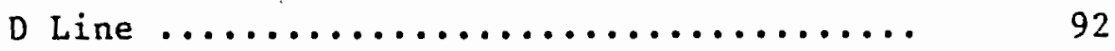

$E$ and $F$ Lines $\ldots \ldots \ldots \ldots \ldots \ldots \ldots \ldots \ldots$

v CONCLUSION $\ldots \ldots \ldots \ldots \ldots \ldots \ldots \ldots \ldots \ldots \ldots \ldots \ldots$

BIBLIOGRAPHY............................. 109

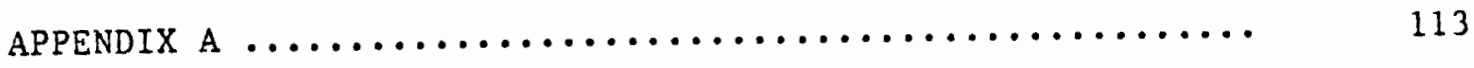

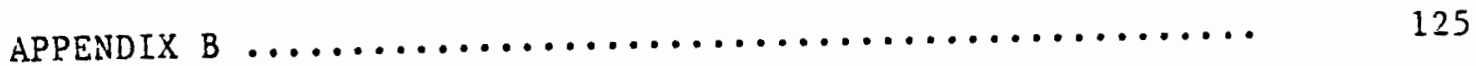




\section{LIST OF FIGURES}

FIGURE

PAGE

1. Location diagram of the study area $\ldots \ldots \ldots \ldots \ldots \ldots \ldots \ldots$

2. Columns showing the stratigraphy at four selected

locations within the study area $\ldots \ldots \ldots \ldots . \ldots \ldots$

3. The Renewable Energy Incorporated lease area.......... 38

4. Location and orientation of the magnetic survey grid .... 39

5. Location and orientation of the gravity survey grid ..... 41

6. Regional Cross section........................ 44

7. Regional Eree Air Anomaly Map................... 46

8. Contoured Free Air Anomaly Map of the

Vale Area........................... 47

9. Gravity line A, showing intial model composed of one

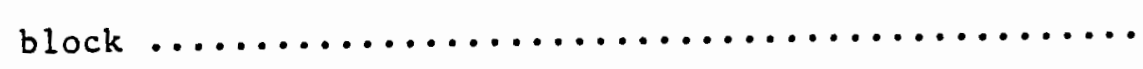

10. Gravity line $A$, showing finished model $\ldots \ldots \ldots \ldots \ldots \ldots \ldots$

11. Gravity line B, showing intial model, composed of one

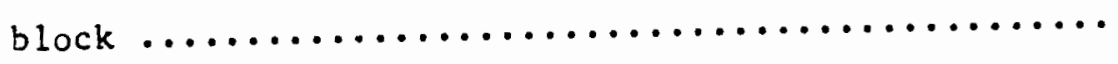

12. Gravity line $B$, showing the finished model of the mass

deficent interpretation $\ldots \ldots \ldots \ldots \ldots \ldots \ldots \ldots \ldots$

13. Gravity line $B$, showing the finished model, showing

the preferced excess mass interpretation .......... 6

14. Gravity line $c$, showing the finished model ........... 68

15. The interpretation of the model of $C$ gravity $l i n e \ldots . . . .70$

16. Gravity line $D$, showing the finished model ........... 72 
17. Gravity line E, showing the finished model .......... 75

18. The interpretation of the model of $\mathrm{E}$ gravity 1 ine ...... 78

19. Gravity line $F$, showing the finished model $\ldots \ldots \ldots \ldots \ldots$..... 81

20. Regional Magnetic Anomaly Map.................... 85

21. Contoured Magnetic Anomaly Map

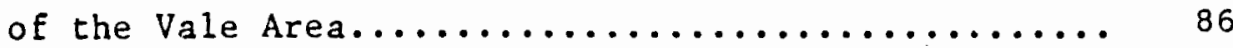

22. Sample magnetic anomaly curves and sources........... 88

23. Sample magnetic anomaly curves and sources............ 89

24. The model of the magnetic anomaly located on magnetic

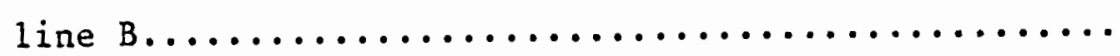

25. The model of the magnetic anomalies located on

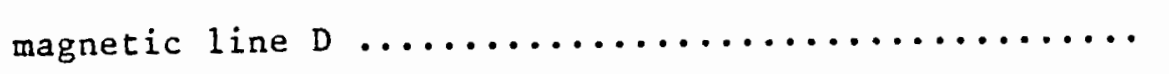

26. The model of the magnetic anomaly located on magnetic

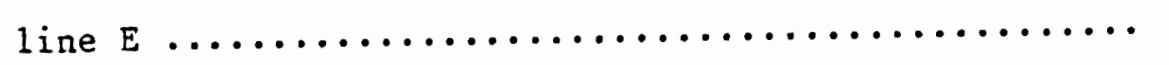

27. The model of the magnetic anomaly located on magnetic
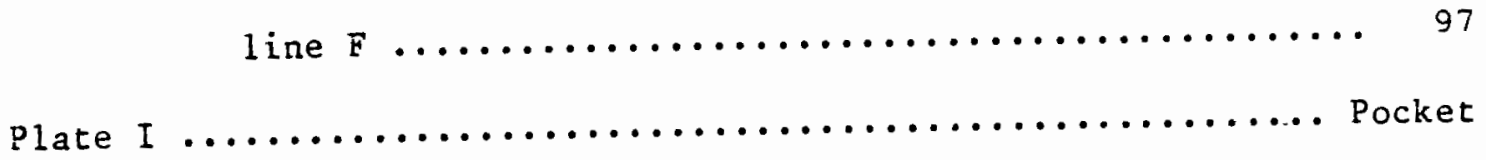

plate II $\ldots \ldots \ldots \ldots \ldots \ldots \ldots \ldots \ldots \ldots \ldots \ldots \ldots \ldots \ldots \ldots$ Pocket

Plate III .......................................... Pocket 
CHAPTER I

\section{INTRODUCTION}

The Vale area has been under investigation to utilize the geothermal potential, since its designation as a Known Geothermal Resource Area (KGRA). The geothermal potential is manifested by an unusually high heat flow and by hot springs located near the base of Rhinehart Buttes (Bowen and Blackwe11, 1975). The location of the hot springs is evidence that the upwelling geothermal fluids are being controlled by the geologic structure (Bowen and Blackwell, 1975).

\section{Purpose of the Study}

Previous investigations conducted within the Vale KGRA have been primarily on a regional scale, aimed at identifying large scale geologic features. Very little detailed work which would be directly applicable to the commercial utilization of the energy potential which may exist in the Vale KGRA has been published. The purpose of this investigation is to use field mapping, and gravity and magnetic surveys, to delineate the detailed structure of the area around Vale. By investigating and detailing the structures of the Vale area, those which are acting as controls on the upper portion of the geothermal system are also to be delineated. The structural detail found in this investigation when added to previous work enhances our knowledge of 
the Vale KGRA.

The purpose of the gravity survey is to define and delineate structures which occur within 500 meters of the suface to define the various fault systems which occur throughout the vale area.

The magnetic survey is used to detect those structures which extend to the magnetic basement. The depth, orientation, and the amount of offset in the magnetic basement has been obtained through modeling of the data obtained in the magnetic survey.

The field mapping has examined physical evidence for, and delineated those structures which extend to the surface. However, many of these structures may not be detectable through field mapping alone. The use of aerial photographs allows the tracing of many of these fault systems.

The results from each of the study techniques will be first examined separately. The results will then be correlated and compared. The several lines of independant evidence then allow a composite picture of the structure to be developed. The field mapping supplied data for the location of the structures on the surface. Gravity and magnetic surveys supplied data on those structures which extend to various depths beneath the surface.

\section{Geographic Setting}

The Vale KGRA is located in eastern Oregon, about 30 kilometers west of the Idaho border, as noted in figure I. In general, topography in the area is controlled by the resistance of the country rock to 


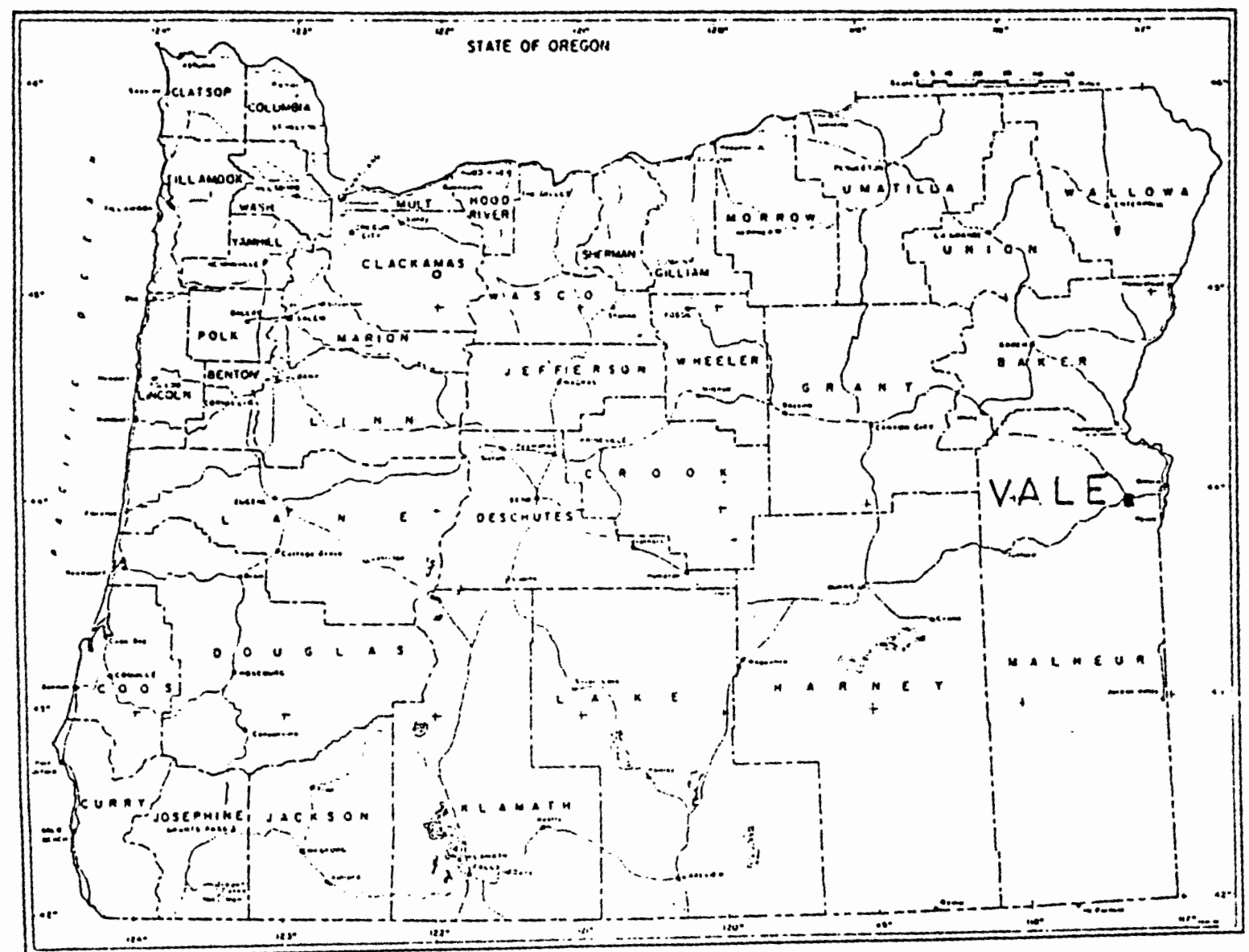

Figure 1. Location diagram of the study area 
erosion. Where the country rock is weakly or poorly consolidated the topography consists of rolling hills of low relief. The areas of higher elevation and more rugged relief are generally underlain by more resistant volcanic or intrusive rocks.

The town of Vale is located in the Malheur River valley. The Malheur River flows east and empties into the Snake River near Ontario, Oregon. The area is surrounded on the northern, western, and southern sides with highlands which descend gradually toward the Snake and Malheur Rivers.

Thirty kilometers to the south are the closest upland areas, the Owyhee highlands. The Owyhee highlands are composed of resistant rocks, the Owyhee Basalt and the Idavada Volcanics. The elevations are in excess of 1800 meters. The highlands to the west are similar to the Owyhee area, rising to about the same elevation and composed of resistant igneous rocks. To the north rises the upland of Juniper Mountain, at an elevation of 2000 meters.

The study area is located in the northwest portion of the vale East 7.5 minute quadrangle. The topography consists generally of rounded hills of moderate relief, with the exception of Rhinehart and Vale Buttes. The Buttes are composed of more resistant rocks and are an area of rugged relief. Vale Butte is the highest elevation in the quadrangle at 965.9 meters. The town of Vale lies at the foot of Rhinehart Buttes with an elevation of about 684 meters, which is the lowest point in the area.

The climate is semi-arid, with an annul precipitation of about 25 $\mathrm{cm}$, is largely confined to winter and early spring. The temperature 
$\circ$

varies from a winter minima of -16 C to a summertime maximum of about 0 30 C (Kittleman, 1967).

Vegetation is sparse and consists of grasses, varieties of sage, and junipers which are found in areas of higher elevation and more precipitation. The vegetation within the study area consists of both long and short grasses and sagebrush. The vegetation was never too thick to impede access, particularly foot travel, and was short enough to ensure ease of surveying, even at long distances cross country.

The region is sparsly populated, and there are few hard surfaced roads. Although there are many unpaved roads and jeep trails these are only seasonably passable and generally only to four wheel drive vehicles. Of historical note, Lytle Boulevard which runs south-east from Vale through the study area follows the route of the Oregon Trail (see, Plate I) which is still visible as deep ruts in some parts of the area.

\section{Previous Work}

Cope (1883), compiled the Eirst reconnaissance maps of the area around Vale. Working on what he believed to be the sediments of ancient Lake Idaho, he mapped them in the Vale area and areas to the east in Idaho. The older Payette beds of western Idaho and the Snake River plains of Oregon were mapped by Lindgren (1898).

The area of the Owyhee upland was studied by Bryan (1929) who mapped the Payette and Idaho Eormations as seperate units. Renick. (1930) worked in the eastern part of the Owyhee region. Work by Kirkham (1931) was done mainly in the Snake River plain and summarized 
the work of previous authors concerning the Idaho and Payette formations. The units present in the owyhee upland are not exposed in the study area, but are stratigraphically lower than those exposed around Vale and may underly the Vale area.

In 1953, the Mitchell Butte 30 minute quadrangle was mapped as University of Oregon Master's theses by Corcoran, Doak, Porter, Pritchett and Privrasky. The Vale area is located in the northern central portion of the Mitchell Butte quadrangle. The geologic map prepared by Corcoran et al, was presented in 1962.

Another series of theses, both Ph.d. and Masters were done in the Owyhee region in the early 1960's. Johnson (1961) compiled the stratigraphy of the Deer Butte Formation. Russell, (1961) Green (1962) McMurray (1962) Weeden (1962) and Kittleman (1962) and Hagood (1963) all mapped portions of the Owyhee region. These theses were compiled by Kittleman (Kittleman et al, 1965). The areas mapped all lie south of the Vale area and are stratigraphically lower than those units exposed in the study area. Certainly some of these units underly the vale area, and some of them such as the Owyhee Basalt are potentially excellent geothermal reservoir rocks.

The stratigraphy of the Western Snake River plain, which includes portions of the Owyhee region was described by Malde and Powers (1962). In 1982 Brown provided a detailed map of the Vale East 7.5 minute quadrangle. 
CHAPTER II

REGIONAL GEOLOGY

\section{Regional Geologic History}

There are 5400 meters of Cenozoic rocks exposed in south eastern Oregon (Kittleman et al, 1965). The rocks range in age from the late, or possibly middle, Miocene through the Pleistocene. The ages obtained are based both on mammalian fossil assemblages and radiometeric dating techniques (Kittleman et al, 1965). As a whole the stratigraphic sequence can be described as a complex series of lenticular sedimentary deposits with intercalated volcanic flows deformed by both syndepositional and postdepositional Basin and Range style faulting (Kittleman et al, 1965). The volcanic rocks range from effusive basalts to rhyolite and explosive rhyolitic ash flow tuffs. Although there are no volcanic rocks exposed in the study area, some or all of these rocks may underly the area at depth. The sedimentary beds are primarily volcaniclastic in nature, but there are a few units which contain a significant portion of granitic detritus. The sediments were deposited in both fluvial and lacustrine, continental environments in a 
series of discreet north trending basins (Kittleman et al 1965). The oldest rocks exposed in south-eastern Oregon are those of the Sucker Creek Formation. The Sucker Creek Formation is composed of predominantly volcaniclastic sediments with intercalated volcanics. Evernden and James (1964) reported a date of 16.7 my obtained by potassium argon dating from a basalt flow near the base of the formation.

The Sucker Creek Formation is unconformably overlain by the late Miocene Owyhee Basalt. The Owyhee Basalt is a thick multiple flow sequence composed of at least 12 flows (Kittleman et al, 1965). An unconformity marks the contact between the Owyhee Basalt and the overlying Deer Butte Formation. The Deer Butte Formation is primarily volcaniclastic in nature, with some intercalated basalt flows and some widespread conglomerate beds composed primarily of granitic detritus (Johnson, 1962; Kittleman et al, 1965). Kittleman et al (1965) has suggested that the occurrence of the granitic conglomerates is due to the filling of the depositional basin, with the conglomerate beds encroaching from the normal position of peripheral deposition. The Deer Butte Formation is late Miocene to early Pliocene in age (Kittleman et al 1965).

Unconformably overlying the Deer Butte Formation is the Grassy Mountain Formation. Kittleman et al (1965) revised the stratigraphic nomenclature to upgrade the Grassy Mountain Basalt to the Grassy Mountain Formation. This revision was necessitated because the Grassy Mountain unit was not entirely composed of basalt. As part of the revision all post Deer Butte, pre Grassy Mountain Basalt sediments were 
included in the Grassy Mountain Formation. This involved the relegation of the Corcoran et al (1962) Kern Basin Formation to the status of a member of the Grassy Mountain Formation. The lower members of the Grassy Mountain Formation, such as the Kern Basin member are primarily volcaniclastic in compostion. The age of the Grassy Mountain Eormation is given in Storm (1975) as early to middle Pliocene. The Grassy Mountain Formation does not crop out in the study area, although the basalt member has been encountered in drilling operations (Brown, 1982).

The Grassy Mountain Basalt was described by Bryan (1929) as massive basalt, with flows up to 40 meters thick and intercalated sediments. The total thickness may exceed 350 meters (Newton and Corcoran 1963). Storm (1975) gave an estimated total thickness of 700 meters to 900 meters. The total thickness of the Grassy Mountain Formation was 1 isted as 750 meters to 1050 meters, based on drilling logs by Bowen and Blackwel1 (1975). The Grassy Mountain Formation unconformably overlies the Deer Butte Formation of Corcoran (1962). The Grassy Mountain Formation, which underlies the Chalk Butte Formation in the Vale area (Brown, 1982) is suggested by Bowen and Blackwell (1975) to contain an excellant geothermal reservoir rock in the Grassy Mountain Basalt member.

Unconformably capping the Grassy Mountain Formation are a series of volcaniclastic beds mapped by Corcoran et al (1962) as the Chalk Butte Formation. The Chalk Butte Formation occurs above the Grassy Mountain Basalt member of the Grassy Mountain Formation, which is the basis of the division between these two formations. The beds of the 
Chalk Butte Formation have been assigned an age of Blancan, though Brown (1982) suggested that they may be as old as Hemphillian. The environment of deposition, is fluvial and lacustrine (Corcoran et al 1962). Occuring within the Chalk Butte formation are small scattered intercalated basalt flows. The Chalk Butte Formation, named by Corcoran et al (1962), is of middle Pliocene age, estimated as Hemphillian by J. A. Shotwell, based on vertebrate fossils (Corcoran et al, 1962). The Chalk Butte Formation consists of loosely to poorly consolidated, tuffaecous sandstones, siltstones and conglomerates. These beds were deposited in fluvial and lacustern environments (Corcoran et al, 1962). Also present within the Chalk Butte Formation are thin beds of ash, tuff, fresh water limestones and thin basalt flows. Brown (1982) redescribed the rocks of the Chalk Butte Formation occuring in the Vale East Quadrangle. Capping the entire sequence is Brown's (1982) unit named the sedimentary rocks of Captain Keeney Pass. These rocks are very poorly consolidated tuffaecous siltstones, sandstones and volcanic conglomerates of middle Pliocene to early Pleistocene age.

Following the deposition of the Chalk Butte Formation, the area was subjected to deformation associated with the Snake River Downwarp and Basin and Range extension. The deformation that accompanied the Snake River Downwarp is reflected in the eastward dip of the beds throughout the area. The Basin and Range deformation is characterized primarily by north - south trending faults. Kittleman et al (1965). reports that the faults tend to be normal and dip steeply. 
Displacement along the faults tends to be small, though a few are measured in the hundreds of meters.

Following the earlier portion of Basin and Range deformation, the beds referred to by Brown (1982) as the sediments of Captain Keeney Pass were deposited. Brown (1982) believes these rocks to be Pleistocene in age. Again the beds are primarily volcaniclastic in composition. The sediments of Captain Keeney Pass were deposited unconformably upon the Chalk Butte formation and differ in color, texture, and degree of consolidation from the underlying Chalk Butte Formation. The beds of Captain Keeney Pass are generally a light gray in color, while the Chalk Butte sediments are yellow brown. The grain size of the beds of Captain Keeney Pass are also finer, though the rock types are the same. The Chalk Butte sediments are also more competent and show a higher degree of lithification. The beds of Captain Keeney Pass were unconformably deposited on and were not disturbed by the earlier Basin and Range structures. This would suggest that this easrly period of deformation had been concluded by the Pleistocene. The beds of Captain Keeney Pass are, however, offset by faults that are believed to part of the Vale Fault Zone, believed by Lawrence (1976) to be a major right lateral strike slip fault zone. The Vale Fault Zone was probably active during the sometime between the Pleistocene to Recent. The structures associated with the Vale Zone also appear to offset the earlier Basin and Range structures. 


\section{Regional Structural Geology}

The study area is located at the west end of the Snake River Downwarp, at the northern edge of the Basin and Range province. The structural position is reflected by the regional eastward dip of the beds in the Vale area. The Snake River Downwarp is a large structural trough which extends eastward from eastern Oregon across Idaho to the vicinity of Yellowstone Park. Cooper (1980) gave a Miocene to Pliocene age for the active period of deformation, during which the trough received thousands of meters of sediments.

The study area, and the areas to the west and south, are dominated by north trending normal faults that typify Basin and Range style structure. The regional structure, as defined by Bowen and Blackwell (1975), Lillie (1977), and Cooper (1980) shows horst and graben features. U.S. Department of Interior, Bureau of Land Management, Environmental Anaysis Report OR-030-4-1 (1975) suggests that there may be more faults within the area than previously mapped. The B.L.M. report stated that the faults are difficult to detect due to the nature of the poorly consolidated Pliocene cap rocks. Brown (1982) reports that beds of Captain Keeney Pass which cap the area are Pliestocene, not Pliocene, in age, based on mammalian fossils. The Pleistocene beds unconformably cap some of the earlier Basin and Range structures, while being offset by other later structures, indicating that deformation was still occurring during the Pleistocene.

Lawrence (1976) suggested the existence of a major right lateral 
fault zone trending through the Vale KGRA. He has named this feature the Vale Fault Zone. Bowen and Blackwell (1975) identified the northern portion of this fault as the Willow Creek Fault. The Willow Creek fault, located northeast of Vale, is a westward dipping normal fault, which trends to the northwest. If the Willow Creek Fault also has a right lateral strike slip component, as reported by Lawrence, (1976), then the overall sense of movement is oblique. The Bully Creek fault, named by Bowen and Blackwell (1975), lies to the west of Vale is an eastward dipping normal fault. The Bully Creek and Willow Creek faults are the bounding structures of a large regional horst and graben combination. Further clarification as to the nature and sense of movement also supplied by Lillie ( 1977 ), who stated that regional scale geophysical evidence indicates oblique movement along the Vale Fault Zone. The Basin and Range structures of the Vale area display extension in the northeast-southwest orientation; superimposed upon this is a northwest trending, right lateral strike slip feature, the Vale fault zone. 


\section{CHAPTER III}

\section{GEOLOGY OF THE VALE AREA}

\section{Stratigraphy of the Vale Area}

\section{Chalk Butte Formation}

Approximately 200 meters of continous section is exposed at Vale Butte. Brown (1982) reported the contact of the Grassy Mountain Basalt at a 200 meter depth in the Two States 0 il and Gas well, located north of Rhinehart Buttes, in the Malhuer River floodplain, see Plate I. An estimate of total thickness for the study area, based on well data and exposed sections would exceed 500 meters. Accordingly about $1 / 2$ of the section is exposed at Vale Butte. Bowen and Blackwell (1975) give a total thickness of the Chalk Butte Formation in the Cow Hollow area, about $15 \mathrm{~km}$ to the south as 750 to 1050 meters.

The rocks exposed consist predominantly of tuffaecous siltstone, with lesser amounts of volcanic sandstone and conglomerate. The relationships displayed by the sediments within the Chalk Butte formation are complex. The deposits are typically lenticular and laterally discontinous. The beds display cut and fill structures and forset-topset combinations are common. Beds interfinger and pinch out over relativly short distances. Beds are commonly truncated in conspicous angular unconformities. 
Chalk Butte beds are grouped into sequences. A sequence, as used here, is a group or series of beds, which displays a form and order that is common throughout the study area. That form is a continuous coarsening upward grain size, progressing from fine silt to sand and somtimes up to boulder. In general a typical sequence consists of a thick siltstone bed, usually more than ten meters in thickness. The siltstones range from massive, with very little internal structure to finely laminated. The grain size coarsens upward, grading to sand size, or sometimes being unconformably overlain by sandstones. Within the sandstones the coarsening progression continues until grading to or truncated by a conglomerate. The sequence is then repeated with the renewed deposition of fine silts. Occasionally, the coarsest fraction is sand size, in which case the sandstones are unconformably overlain by fine silts. This progressively coarsening upward sequence is repeated four times in the continous section exposed at Vale Butte (see Plate 1).

Because of difficulties in establishing absolute correlation between exposures located in the study area, each of the locations will be examined seperately. Consequently, stratigraphic columns are shown seperately for each of the major exposures. The exposures are located in an unnamed gulch which trends northwest through sections 5,6 , and 8 , R45E, T19S; in an unnamed valley in the SW/4 sec. 4 and SE/4 sec 5 , R45E, T19S; at Rhinehart Buttes; and Vale Butte. The columnar sections are shown in figure 2, and the locations are noted on the geolgic map, Plate I. 


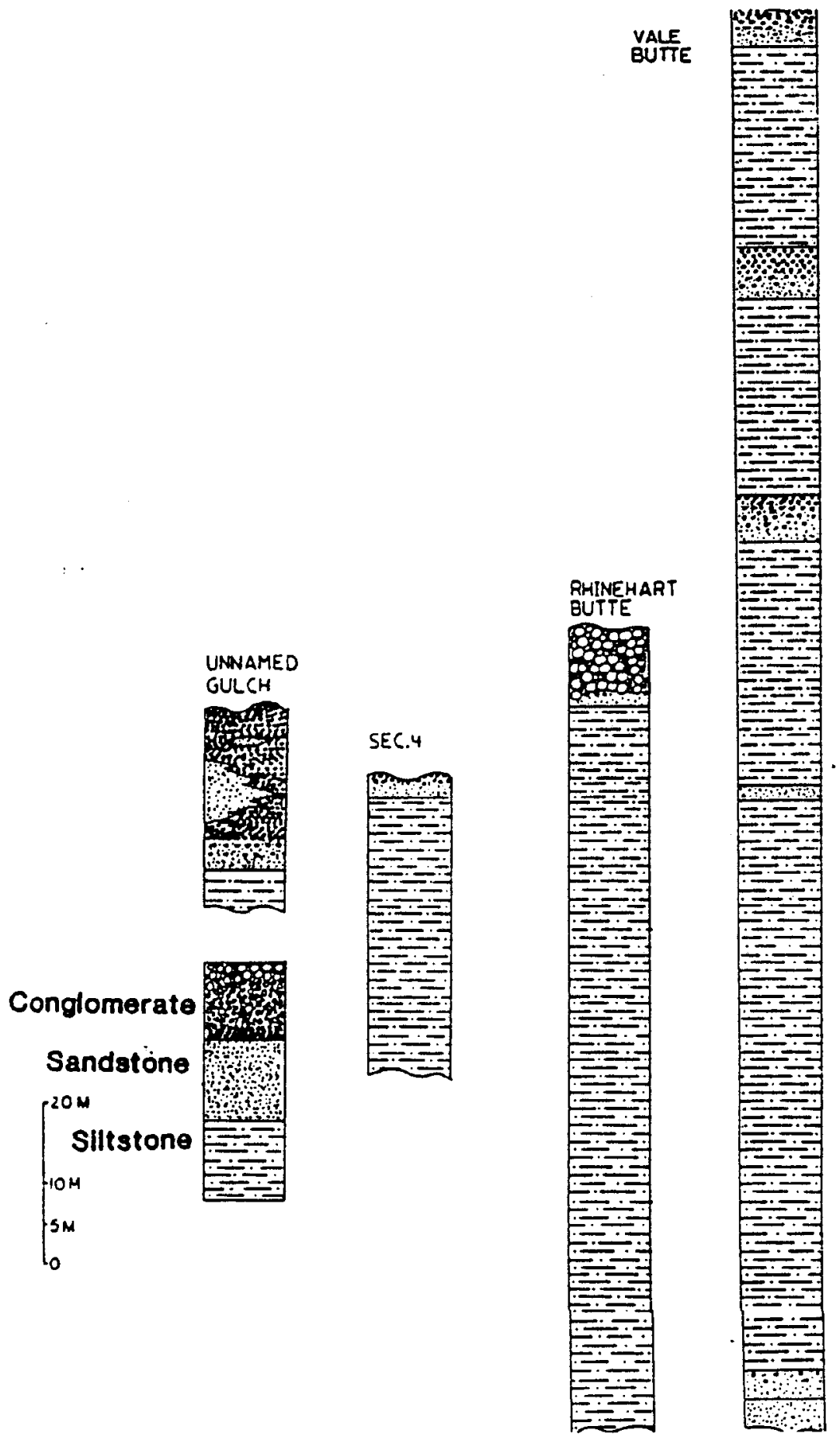

Figure 2. Columns showing the stratigraphy at four selected locations within the study area 
In the westernmost unnamed gulch location, about five $\mathrm{km} \mathrm{SW}$ of Rhinehart Buttes, is a sequence which displays variability. The dips of the beds vary between north and northeast, therefore, progressing to the southeast along the gulch the rocks exposed are continously lower in the section. At the mouth of the gulch, in the SE/4 sec. $6, T 19 S$, R45E, a well stratified pebble conglomerate crops out. The total thickness is approximately 20 meters. The beds range in thickness from five cm to over one meter. Within the conglomerate are lenses of fine grained sandstone up to five meters thick. The pebbles are primarily well rounded basalt, with lesser amounts of quartz, and chert, in a coarse sandy matrix. Sedimentary structures include truncated beds, foreset beds, and cut and fill structures.

Directly beneath the conglomerate, exposed in the $\mathrm{SW} / 4 \mathrm{sec} .5$, is a massive-cliff forming sandstone. Approximately 35 meters of competent, medium grained, volcanic sandstone is capped by about 20 meters of the conglomerate beds exposed at the mouth if the gulch. In the NE/4 sec. 8, an underlying basal siltstone is exposed. The siltstone beds are about 30 meters thick. The entire sequence displays the typical coarsening upward character both within the beds and in the gross lithology of the sequence.

In the location in the SW/4 sec. 4, T19S, R45E, about 30 meters of section is exposed. The rocks of this location can be correlated to the sequence exposed in the unnamed gulch to the west. The cap rocks are sandstone and conglomerate beds. These beds are much thinner here, being only about two meters in total thickness. The contact between the underlying siltstone and the overlying coarse grained beds is 
unconformable. At the base of the conglomerate beds is a layer of imbricated basalt cobbles in a coarse tuffaecous, sandy matrix. The bedding is parallel to the contact and the bed is about eight $\mathrm{cm}$ thick. Deposited on top is a series of small (2 cm thick) basalt pebble beds. The basalt pebble beds are tuffaecous, matrix supported, and the bedding is foreset. The matrix is also much finer grained than the basal bed. Overall grain size of the beds at this location is consistantly finer and the bedding is thinner than at the unnamed gulch location. The same sedimentary structures occur at this location, but their size is smaller.

There are many exposures in the Rhinehart Buttes area. To be able to relate the exposures and correlate them where possible the locations are described in relation to the structure. However, the area contains a large number of faults. The northwest trending fault along the crest of Rhinehart Buttes is the princple one. This fault is here informally named the Rhinehart Fault. Exposures in the Rhinehart Buttes area are catagorized as being either west or east of Rhinehart fault. At least five east-west trending faults cross the northern portion of Rhinehart Buttes, resulting in many exposures seperated by faults. Where exposures are of the same rock type, notably siltstone, correlations cannot be made with absolute certainty.

The lowest portion of the sequence exposed on the west flank Rhinehart Buttes is about 70 meters of the siltstone which forms the base of the western slopes of the northern Butte. The upper portion of this unit coarsens upward and grades upward into the overlying sandstone beds. 
The sandstone beds range between one and two meters in thickness and are recemented with silica. The sandstones are fine grained, the silicification has obscured any primary depositional structures within the beds. These sandstone beds are truncated by conglomerate.

The conglomerate which forms the caprock of the west face of Rhinehart Buttes is variable. The exposures in the SW/4, SW/4 of section 28 are limonite stained, silicified boulder conglomerate (Brown, 1982). The bed is apparently massive, approximately ten meters thick. Again, as in the sandstones beneath them, the primary structures are obscured. The clasts are mostly basalt, about $80 \%$, with about $20 \%$ white, alpha, quartz. The massive conglomerate at this location seperates laterally to the northwest into two distinct beds. The lower conglomerate is approximatelly one and a half meters thick and is matrix supported, friable, basalt, pebble, conglomerate. The beds are thin, about two $\mathrm{cm}$ thick, and consist of basalt pebbles, in a silty, fine grained, tuffaecous matrix. The outcrop is located about 200 meters from Rhinehart Fault and shows no evidence of

silicification. The upper bed, at the same outcrop, is about 10 to 15 meters thick, and is a silicified basalt pebble conglomerate. The upper conglomerate is clast supported, with uniform bedding about $10 \mathrm{~cm}$ thick. Although it is silica flooded, it does not show limonite staining.

East of the Rhinehart Fault, in the valley between Rhinehart and Vale Buttes, a different sequence is exposed. The lowest rocks exposed in this section are sandstones. The sandstone is composed of two distinct members. The basal member is a well lithified, fine grained, 
volcanic sandstone which is partially silicified. The degree of silicification is highest in the area of Rhinehart Butte and diminishes with distance away from Rhinehart Buttes. The bed varies in thickness, from less than one meter to three meters. This sandstone is thinnly bedded and the beds are approximately one $\mathrm{cm}$ in thickness. These sandstone beds are resistant, competent beds which form the prominent dip slope in the valley between Rhinehart and Vale Buttes.

Conformably overlying the basal sandstone beds is a friable, medium grained, matrix supported, tuffaeceous, volcanic sandstone. This sandstone displays some silicification, but the silicification is limited to areas immediately adjoining fault zones. Grain size within the sandstone coarsens upward, with occasional well rounded basalt pebbles occuring in the upper one third of the outcrop. The frequency of the pebbles increases upward, although volumeterically the pebbles never reach more than a very minor portion of the sandstone estimated at a maximum of five percent. Because of the lack of resistance to erosion of this bed the original total thickness is not exposed. Generally, in outcrop, this sandstone is approximately two meters thick, with the upper contact removed by erosion. Bedding within this sandstone is of variable thickness ranging from one $\mathrm{cm}$ to $20 \mathrm{~cm}$. Climbing ripples were noted indicating a fluvial origin and suggesting that the paleocurrent direction was northward. Exposures are limited; and the bed is chiefly a slope former. This sandstone forms slopes on the east face of Rheinhart Buttes and flat irons in the valley between Rhinehart and Vale Butte. The flat irons are located in the SE/4 of sec. 28 and the NW/4 of sec. 33, T18S, R45E. The best exposures of the 
bed occur in a resistant silicified portion in a strean cut on the line between secs. 33 and $34, T 18 \mathrm{~S}, \mathrm{R} 45 \mathrm{E}$. The contact relationship with the overlying unit is uncertain. On the east flank of Rhinehart Butte, in sec. 28 the sandstone beds are apparently capped by siltstone. The nature of the contact between the sandstone and siltstone is not known. The only exposures of the overlying siltstone noted were in the silicified portion imnediately adjacent to Rhinehart Fault. Because of the limited exposure no bedding, and/or depositional stuctures were observed. Where there were exposures the siltstones were noted as being silicified, limonite stained, and highly fractured. The fractures are filled with secondary, geothermally deposited calcite and quartz.

The northern portions of Rhinehart Buttes is crossed by at least five northwest trending normal faults. The exposures in this section are limited to steep faces of siltstone. The sandstone or conglomerate beds which were found in the southern portion of Rhinehart Buttes are not exposed. Most of the exposures of the siltstone are in areas of silicification very near the faults. The north face of Rhinehart Buttes is composed of a 55 meter thick section of siltstone exposed in a road cut on highway 20 at the base of the butte. The outcrop displays pervasive shearing. This shearing might be attributed to blasting during road construction, however this location is very near several fault locations, which might more likely be responsible for the structure. The siltstones are not silicified but silicification has occurred along some of the faults in the area. The siltstone is capped by 15 meters of thick, forset bedded sandstones. The sandstones are 
fairly uniformly bedded, about $10 \mathrm{~cm}$ thick are fine grained and flooded with silica. The contact between the siltstone and sandstone was not found. Exposures are limited to seperated outcrops of either of the rock types.

Above the sandstone is a thick bed of siltstone. The siltstone forms the upper half of the north face of Rhinehart Butte. Outcrops are rare, limited to those which have been silicified and display limonite staining. The topographic expression, and intensity of the silicification suggests that fault contact is very likely.

The description of the north face of Vale Butte is very similar to that of Rhinehart Butte. The rocks display variable thickness in both bedding and total thickness. The coarse grained rocks at the north face of Vale Butte are conglomerates, not sandstones. The total thickness of these particular conglomerate beds varies from as little as three meters to over 15 meters. The individual beds range from ten cm to about one meter in thickness. The conglomerate is clast supported and has been flooded with silica. Limonite staining is present, but only mildly so and limited to the western portion of the beds. The staining decreases with distance eastward along Vale Butte. The rest of the north face of Vale Butte, up to the level of the middle conglomerate bed, see the stratigraphic column, figure 2, Vale Butte section, is composed of siltstone. The sandstone and conglomerate beds which occur in the rest of the Butte do not crop out on the north face. Either the beds have been faulted or are pinched out or perhaps are merely covered.

Vale Butte is, with the exception of the north face, composed of a 
series of siltstone through sandstone/conglomerate sequences. A total of four sequences make up the Butte and are traceable through the west, south, and east side of the Butte. Vale Butte is the thickest (approximately 240 meters) unfaulted exposed stratigraphic section within the study area. The lowest exposures are sandstone. The sandstone is composed of two distinct sandstone types, lithologically very similar to those located on the eastern flank of Rhinehart Buttes. This outcrop is seperated from the Rhinehart Buttes sandstones by a fault.

Overlying the sandstones is a massive siltstone. The siltstone is about 60 meters thick. Unconformably capping the siltstone is a sandstone bed about one meter thick. The bedding is massive, and the composition is a coarse grained tuffaecous, sandstone. Within this sandstone are numerous vertically standing casts of trees. The trees include root casts extending into the underlying siltstone beds. The casts are limited to trunks and roots with no leaves or limbs preserved. None of the trees exceeds $10 \mathrm{~cm}$ in diameter, indicating that the buried forest was probably quite young. Apparently a forest was growing on the floodplain of the fluvial system and was subsequently buried after a few but indeterminate number of years. Three sequences composed of siltstones and conglomerates are deposited conformably above the sandstone. The sequence begins with 60 meters of slope forming siltstone. The siltstone is overlain by approximately six meters of resistant, limonite stained silicified conglomerate. The conglomerate beds are poorly stratified, composed of mostly basaltic pebbles, with less than $15 \%$ quartz pebbles. The beds are 
clast supported and range in thickness from $10 \mathrm{~cm}$ to about one meter. The beds have been flooded with silica. These resistant conglomerates are cliff and bench formers. The conformable sequence continues with 25 meters of slope forming siltstone and is capped by about eight meters of silicified, limonite stained, clast supported, pebble conglomerate. The capping conglomerate is silicified, limonite stained, consisting of primarily basalt clasts in a coarse sandy matrix. As in the case of the previous conglomerate this rock is a resistant cliff and bench former. Above this is the fourth and topmost sequence. The top sequence is made up of about eight meters of siltstone and about six meters of silicified conglomerate which acts as a cap rock on the top of Vale Butte. The conglomerate is very similar to the other conglomerates which occur in this sequence.

\section{The Rocks of Captain Keeney Pass}

Capping the Chalk Butte formation is the unit described by Brown (1982) as the sedimentary rocks of Captain Keeney Pass. These rocks are very poorly consolidated with limited exposures, and differ from the underlying Chalk Butte formation in color, texture, and degree of lithification. While the rocks of the Chalk Butte Formation are predominately light yellow brown in color the sediments of Captain Keeney Pass are light gray. The sediments of Captain Keeney Pass are not as well indurated as the underlying rocks. The sediments of Captain Keeney Pass are are also different in the expression of erosion. Maximum thickness of the sediments of Captain Keeney Pass is 100 meters on the hill in the center of sec. 3 R45E, Tl9s. Contacts 
beneath and within this unit are obscured so no definite thicknesses of individual beds were determized. The variation in rock types are visible at this location, when viewed from a distance due to changes in vegetative cover. The rocks of Captain Keeney Pass, like the sequences within the Chalk Butte Formation generally coarsen upward. The unit consists of a lower siltstone member, which is tuffaecous and very fine grained, a medium grained volcanic sanstone member, and remnants of a capping bed of matrix supported basaltic pebble conglomerate. The composition of the beds was determined by examining float. Also within this unit is a thin bed of light gray air fall ash. Only small remnants of this ash bed remain, located in the upper portion of the sequence.

\section{Structural Geology of the Vale Area}

The study area is dominated by north to northwest trending topographic lineations. These lineations are formed by the valleys located just west of Rhinehart Buttes, on either side of Vale Butte, and the unnamed valley which trends northwest through sections 5,68 , and 9. The buttes form a second set of lineations. Rhinehart Buttes and Vale Butte, along with the hills which extend southeast of vale Butte contribute to this set.

Rhinehart Buttes are composed of a resistant silicified rocks. At the crest of north Rhinehart Butte, in the $N$ N/4 of section 33 and in the SW/4 of section 28 , is exposed the westward dipping Rhinehart. Fault, (see Plate I). Rhinehart Fault, has a dip of $74^{\circ}$ to $83^{\circ}$. Slickensides on the fault surface indicate the last movement was down 
to the west. This movement classifies Rhinehart Fault as a normal fault. The fault trends $N 29^{\circ} \mathrm{W}$ and can be traced along the crest of the southern portion of north Rhinehart Butte. The fault trace extends part way down the valley seperating north and south Rhinehart Buttes and in the upper portion of the northern end of south Rhinehart Butte. There is an offset in the location of the fault trace on the opposite sides of the valley. The direction of the offset indicates that the fault located in the valley is down to the south, labelled $I$ on the geologic map, Plate $I$.

Most of the linear ridges located within the study area were found to be cored with more resistant silicification zones. Consequently all areas of silicification were examined for possible structures. The areas of the highest amount of silicification were found to be the intersections of one or more faults (see Plate II, is a map showing silicified rocks). In the $\mathrm{SW} / 4$ of sec. 28 Rhinehart Fault is exposed along the narrow ridge crest, see geologic map, plate $I$, and is offset to the west by the two intersecting faults. In the area of the intersection is exposed rocks that have been highly fractured, fault gouge, and secondary deposition of quartz and calcite has occurred. Progressing away from the intersection, along each of the faults, the degree of silicification and secondary mineral deposition decreases. Northward along the line between secs. 28 and 29 is another fault intersection. Located about the middle of the line, just west of the radio towers is a large tower like outcrop of silicified siltstone. The tower is also marked by conspicous fault gouge, silicification and secondary deposition of quartz, calcite, and selenite. Again the 
degree of silicifcation decreases away from the fault intersection.

Extending to the southeast from Rhinehart Buttes, in the south one half of section 28 is a linear ridge composed of silicified sandstone. The rocks on opposite sides of the silicified zone are of differing type. Northeast is a dip slope consisting of silicified sandstone. Southwest of the ridge is a level area underlain by siltstone, which truncates the sandstone. This suggests that they are offset by a fault, shown on Plate I as A. In the eastern $1 / 2$ of section 33 , the hill with elevation of 2614 is covered by a soft pleistocene sedimentary unit. The Pleistocene sediments are truncated and in contact with older Chalk Butte sandstone in the northern portion of the ridge, see geologic map, Plate I, approximately in line with the interpreted fault. The northern portion this ridge continues to a small north trending valley in the $\mathrm{NW} / 4, \mathrm{NE} / 4$ of section 33 . The narrowest portion of this valley has the shape of a backwards $\mathrm{L}$, with exposures along both walls, which trend north-south and along the eastwest trend which would be the horizontal portion of the $\mathrm{L}$. Those rocks along the north face of the east trending section are fractured and dipping at considerable variance to the regional dip. The regional dip is to the northeast while the fractured rocks display a northwest dip. This is interpreted as a brittle fracturing type of drag folding. The drag folding and apparent offset of units indicates that movement along the fault would be down to the northeast.

The sandstone hill that forms the eastern wall of the valley is the same sandstone which forms the western wall at the SW/4 SE/4 of section 28. The small flatiron on the western side of the valley is 
repeated when crossing the valley from west to east, suggesting a north trending fault occupies the valley. The movement necessary to produce the repetition of this unit is down to the west, labeled $B$ on the geologic map.

Just north of the junction of the above mentioned southeast trending ridge and Rhinehart Butte, the east flank of the Butte consists of a dip slope of sandstone. The southern margin of that dip slope is a small valley. The sandstone bed continues uninterrupted across the valley at about the 2500 foot contour. To the west, the valley records progressively more offset all the way to the junction of the southeast trending ridge. This structure is a hinge fault; the offset is down to the south and increases to the west. Also at the junction of the hinge and the southeast faults, with Rininehart Fault; Rhinehart Fault displays an offset to the west. The offset to the west of Rhinehart Fault fits the suggested sense of movement along the previously described faults.

The same kind of situation occurs at the east trending valley to the north of the dip slope, which is located near the center of section 28. Also the trend of the crest of Rhinehart Buttes is offset along the trend as the valley, and a small amount of alteration was noted along the crest of Rhinehart Butte on the same trend, at this location, noted as fault $C$ on the geologic map. The sandstone dip slope is truncated at this valley and the northern valley wall consists of siltstone. The offset is down to the north, which would make the dip slope the top of a small horst.

In the SE/4 SW/4 NW/4 of section 28 is a small southeastward 
trending knob. This knob shows silicification and limonite staining. Also noted was an apparent offset between the rocks on opposite sides of the small valley at the southern base of the knob. The apparent offset consists of the truncation of distinct beds. The beds occur on the ridge and southern wall of the southeast trending valley that marks the northern boundary of the ridge. Across the valley, to the north the slope consists of siltstone, and the narker bed was not located. In the $\mathrm{SE} / 4 \mathrm{NE} / 4$ of section 33 is a northwest trending valley which parallels the foot of Vale Butte. This valley narrows to a small steep cut just to the south of the 2500 foot contour. The narrowing of the valley is due to a silicified zone of a sandstone bed. Just to the east, in the talus at the base of Vale Butte float contains slickensides. The main northwest trending fault, here informally referred to as the southern extension of the Willow Creek Fault, is located west of the base Vale Butte, identified as WC on the geologic map, Plate I. To the south, a series of unnamed hills forms a lineation along the east side of the trend of the Willow Creek Fault. Fracturing and changes in dip on the hill located in the center of section 34, south of Vale Butte suggests drag folding, with the down thrown side to the west. The hill in the NW/4 of section $11, T 19 S$, with an elevation of 3163 feet has an exposure of the Chalk Butte Formation which is outcropping through the overlying Pleistocene sediments. This exposure suggests that faulting occurred after deposition of the overlying unit and has offset the Pleistocene beds, allowing the removal of the upper beds. The unnammed hill which rises to the east the exposes about 90 meters of Pleistocene sediments. 
A northwest trending fault, labelled as fault $G$ on Plate I, apparently crosses through the saddle located on the northeast ridge of Vale Butte, near the center of section 27 . The north slope of Vale Butte, west of the fault is composed of light yellow brown siltstone, siltstone float and locally weathered soils. Immediately east of the fault, the soils are a dark red brown, the float is composed of limonite stained silicified conglomerate. The juxtaposition of units suggests that the movement is down to the east. The beds which crop out west of this structure dip steeply to the east, and those on the east dip to the east, steeper than the regional dip. This evidence suggests drag folding, with a down to the east movement.

Upslope from the saddle, still on the northeastern ridge of vale Butte, aerial photography reveals that the bench forming conglomerate beds of Vale Butte has been fractured by two small en echelon normal faults. The down to the east offset and fault traces show clearly in the photographs. Both of these structures are down to the east and the estimated offset is between $f i v e$ and ten meters.

At the southern end of Vale Butte there are two small hills. The northernmost is a small mesa like feature, which extends southward from Vale Butte. This hill is located in the $\mathrm{SW} / 4 \mathrm{NW} / 4$ of section 34 . The units composing this hill are apparently the same units forming the southern extension of Vale Butte. The cap rock which forms both of these features is a silicified sandstone overlying an unaltered bed of siltstone. Therefore the fault separating them would be down to the south.

Near the center of section 34 is a small butte. This small butte 
is south, across the northeast trending valley from Vale Butte and is composed of silicified sedimentary rocks. The topographic expression of the valley on the southern side of this butte, together with the alteration suggests a down to the north fault, trending to the southwest. The configuration of the two faults suggests that this fault block is a small graben.

South, the next hill, elevation 2887, exposes, in the valley at its western base an outcrop, which shows the same style of drag folding as found elsewhere. The beds show silicification and are brittly fractured. The crest of hill 2887 shows a small amount of silicification. The unique exposure shows that the Pliocene cap rocks have been altered by silicification. This suggests that the fossil hot springs (Bowen and Blackwell, 1975) were active after the deposition of the Pliocene beds.

In the SE/4 of section 2, T19S, R45E, is a small outcrop of limonite stained, slicified Chalk Butte siltstone. The outcrop is a free standing linear, dike like wall which outcrops through the Pliocene sediments. The strike of this structure is about $\mathrm{N} 30^{\circ} \mathrm{W}$. This orientation coincides with the other northwest trending structures within the area. On trend with this outcrop, several other Chalk Butte outcrops are noted, located on hill 2807, in the SW/4 of section 35, T18S, R45E, and the ridge immediately south, in section 2, T19S, R45E.

In the western part of the study area, several other proposed faults are exposed. In the large unnamed northwest trending valley in T19S, sections 5, 6, 8 , and, 9 displays an offset in units which are downdropped to the west. 
Near the center of the section boundary, between sections 8 and 5 , is a small northward trending valley. Across this valley a small amount of offset can be observed. This valley runs to the north, truncating an outcrop of Chalk Butte Formation rocks, and farther north truncating Pliocene beds. The fault dips steeply to the east and is down to the east, though the offset is less than 10 meters.

\section{The Geothermal System at Vale}

The geothermal system at Vale produces four hot springs, shown on the geologic map, Plate I. The hot springs are located on the southern bank of the Malhuer River, on the flanks of Rhinehart Buttes. The southernmost two are low temperature, 22 and $27^{\circ} \mathrm{c}$. The northern two, located between the bridges of highway 20 , are high temperature. The temperatures measured at these springs is 97 and $98^{\circ} \mathrm{C}$. The analysis of the waters from these two springs, based on confidential data from Renewable Energy Incorperated, indicates that the flow is composed of about $90 \%$ river water and less than $10 \%$ geothermal water. The springs are fed by an aquifer in the recent alluvium in the floodplain located at a depth of about 20 meters. The temperature of the water in the aquifer increases toward the southeast, as measured in the wells which tap the aquifer (Brown, 1982). The temperature increases from about $\circ$ $97 \mathrm{C}$ at the hot springs to a high of about $115 \mathrm{C}$ in a well at the foot of Rhinehart Butte, located southeast of the hot springs. The temperatures of the water in the aquifer decrease both to the north and south of the hot springs. The pattern displayed by the temperatures within the aquifer suggests a point source for the outlet of the 
geothermal system feeding the high temperature waters into the aquifer.

Heat flow measurements in the Vale KGRA ranged from almost two to almost five times the worldwide continental average (Bowen and Blackwel1, 1975). Bowen and Blackwell (1975) reported measuring heat flow values that ranged from $2.8 \mathrm{HFU}$ to 6.4 HFU. Heat Flow Units (HFU) are measured in microcalories per square centimeter per second. The worldwide continental average is $1.4 \mathrm{HFU}$. Black (pers. comm., 1984) stated that to achieve that high a heat flow value convective heat transfer through a liquid medium is necessary. The source of the fluid or reservoir has been suggested by Bowen and Blackwell (1975) to be either the Owyhee Basalt or the Grassy Mountain Basalt both of which are suggested to excellent reservoir rocks. Field mapping has shown that Rhinehart fault was probably the main controlling structure for the fossil geothermal system at Vale (Bowen and Blackwe11, 1975). The present hot springs are located near the trace of Rhinehart Fault. The aquifer that feeds the hot springs shows an increase in temperature east of the trace of Rhinehart Fault. Consequently Rhinehart Fault may not be the controlling structure at source of the geothermal fluids for the aquifer itself.

\section{Silicification in the Vale Area}

The rocks of the Vale area, notably the Chalk Butte Formation display widespread silicification. The areal extent of silicification seems to be controlled by the permeability of the country rock (Benson, pers. comm., 1981). The distance from the faults which controlled the flow of the silica bearing geothermal waters that resulted in 
silicifation is noted generally decreases as grain size of the country rock decreases.

Rhinehart Buttes is an erosionally resistant, silicified fossil hot spring (Bowen and Blackwell, 1975). The main controlling structure of this fossil geothermal system seems to be Rhinehart Fault. The areas of the most intense silicification, which combines limonite staining and secondary mineralization, all occur along the traces of Rhinehart Fault. With an increase in distance away from Rhinehart Fault, first secondary mineralization, then limonite staining and lastly silicification decreases and then disappears. The silicification may extend for up to kilometers away from the fault in what were the more permeable beds. The clast supported conglomerates have been noted to be silicified at and beyond Vale Butte. This distance is greater than one km east of Rhinehart fault. The section about 200 meters to the west of the Rhinehart Fault shows a silicified clast supported conglomerate overlying an unsilicified conglomerate which supported by a fine grained tuffaecous matrix. Coarse grained sandstones display lateral silicification in the range of hundreds of meters. The coarse grained silicified sandstones are found to have a uniform grain size. Those sandstones which are composed of two or more distinct grain sizes, especially those which are analogous to matrix supported rocks show a limited areal extent of silicification. Siltstones, which are noted by Bowen and Blackwell (1975) as being relatively impermeable show silicification within only a few tens of meters around Rhinehart Fault. 
CHAPTER IV

GEOPHYSICS

\section{Introduction}

The region surrounding Vale KGRA has been the subject of numerous investigations; Bowen and Peterson (1970), Bowen (1972), Bowen and Blackwell (1975), Couch et al (1975), Hull (1975), Couch and Baker (1977), Lillie (1977), Applegate and Donaldson (1979) and Boler (1979). Because of the alignment of thermal features along structural lineations the Vale geothermal system is suggested to be of the Basin and Range type (Bowen and Blackwe11, 1975). A critical feature of this type of system is the location of the controlling structures, usually faults, along which the geothermal fluids migrate.

Magnetic and gravity surveys were conducted under the supervision of Dr. Tsvi Meidev, during 1981. Well logs and previous work, principly by Couch et al. (1975) Lillie (1977), Boler (1979), and Applegate and Donaldson (1979), suggested that the necessary geologic parameters to achieve good results with magnetic and gravity surveys existed in the study area. The most important of these parameters was the existence of a basalt unit at a depth of less than one $\mathrm{km}$.

Lillie (1977) reported that the sense of movement along the faults in the Vale area is oblique to normal. Normal faulting would juxtapose basalt and lower density sediments generating a density contrast. The 
horizontal density contrast should result in a gravity anomaly. Basalt has a high value of magnetic susceptibility in comparison to sedimentary rocks. The same structures which good gravity anomalies should result in the generation of a significant magnetic anomaly. However, the critical feature would be the depth to the basalt flows. This parameter is important because of the relationship between depth and the wavelength of a magnetic anomaly. The planned magnetic survey lines were to be approximately three $\mathrm{km}$ in length. So the source depth must be less than one $\mathrm{km}$ to be able to record the complete waveform of a magnetic anomaly.

Berg and Thiruvathukal (1967) reported the results of a state wide gravity survey and published the state map of the Complete Bouguer Anomaly ( $C B A$ ) and the Free Air Anomaly (FAA) values. Thiruvathukal and others (1970) discussed the results of the state survey, particularly with respect to the thickness of the crust and the anomaly patterns. Later workers, Bowen (1972), Bowen and Blackwel1 (1973, 1975), Couch et al (1975), and Hull (1975) delineated the major structures in the vale area. Lillie (1977) and Boler (1979) produced comprehensive magnetic and gravity surveys of the Vale one degree quadrangle. Boler (1979) analyzed the regional scale magnetic anomalies particularly with respect to the depth of magnetic basement and crustal relationships. The study area is located on a regional magnetic high which is caused by a deep seated, about five kilometers, crustal uplift (Boler, 1979). Lillie (1977) refined the picture of the crustal structure in the area 
and also provided both seismic velocities and densities of the proposed crustal sections.

\section{Survey and Data Reduction Procedures}

\section{Magnetics}

The magnetic survey was conducted in March, 1981, under the direction of $\mathrm{Mr}$. Roert 0 . Walston, then the project manager for Renewable Energy Inc. A grid pattern was established which consisted of six lines and was centered on the Renewable Energy Inc. lease, shown

in figure 3. Three of the lines B,C, and D lines were oriented $N 70^{\circ} \mathrm{E}$. The other three lines, E, F, and $G$ were oriented $N 20 \mathrm{~W}$. The Iines were oriented in an attempt to cross the main structural lineations at right angles, as shown in figure 4. A base station was established. Secondary bases, at the terminis of each of the lines and at the $\mathrm{l}$ ine crossover junctions were established and tied to the base station. While the secondary bases were being established, the base station was reoccupied at hourly intervals to check for drift. After establishing of the main and secondary base stations, the magnetic readings were corrected for drift and the corrected readings recorded. The data are shown in appendix $B$.

The magnetic surveying was done on foot at a height of 2.25 meters using a Gisco proton precession magnetometer. Station separation, within the lease boundaries was 30 meters ( $100 \mathrm{ft.}$ ). Outside the periphery of the lease, the separation was expanded to 76 meters ( 250 ft.). On those lines which extended more than one $\mathrm{km}$ beyond the lease 


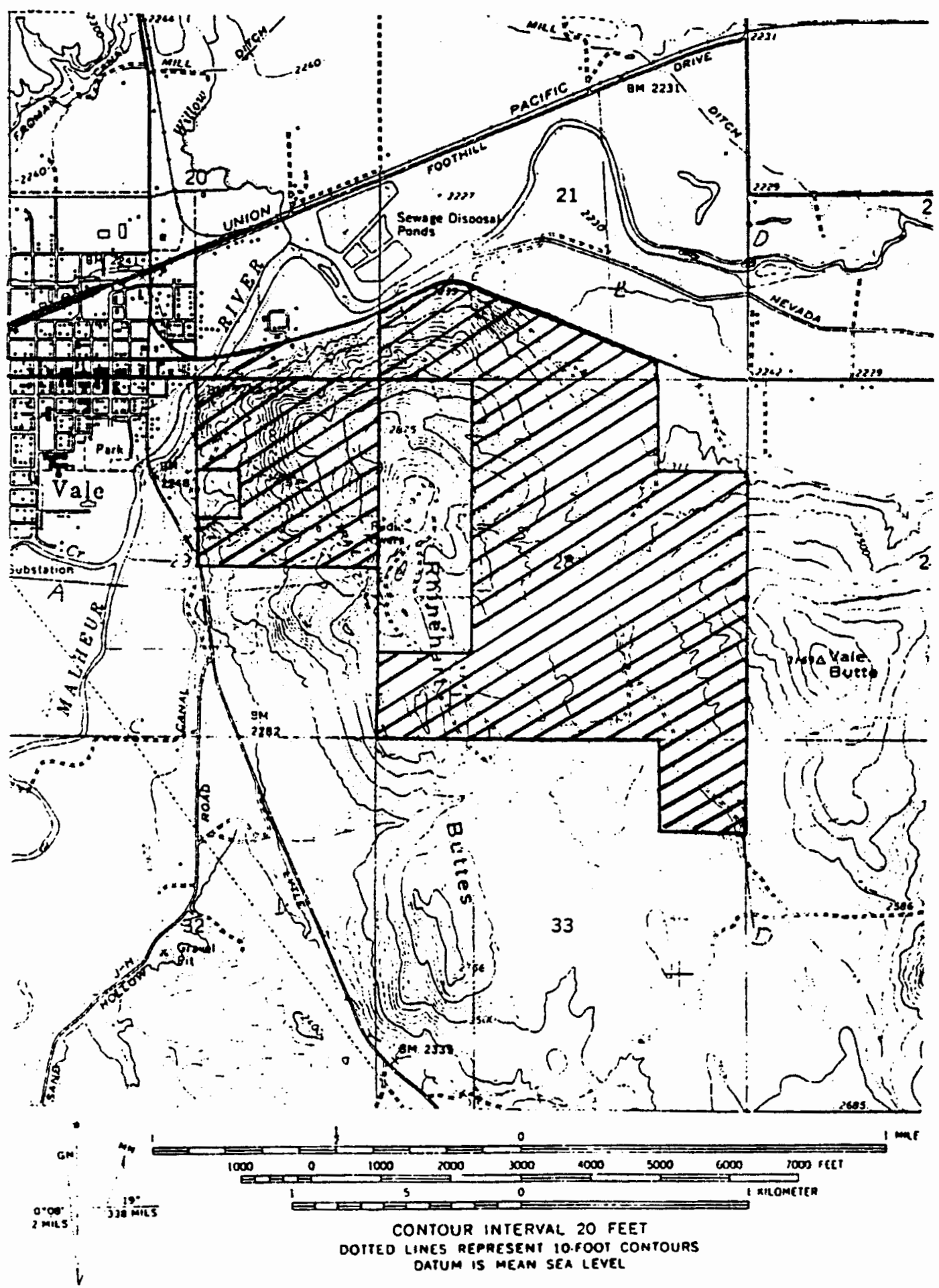

UIM GANO AMO ING] MAGME IKC MONIM

oEcumation al cenien of smers

Figure 3. The Renewable Energy Incorporated lease area 


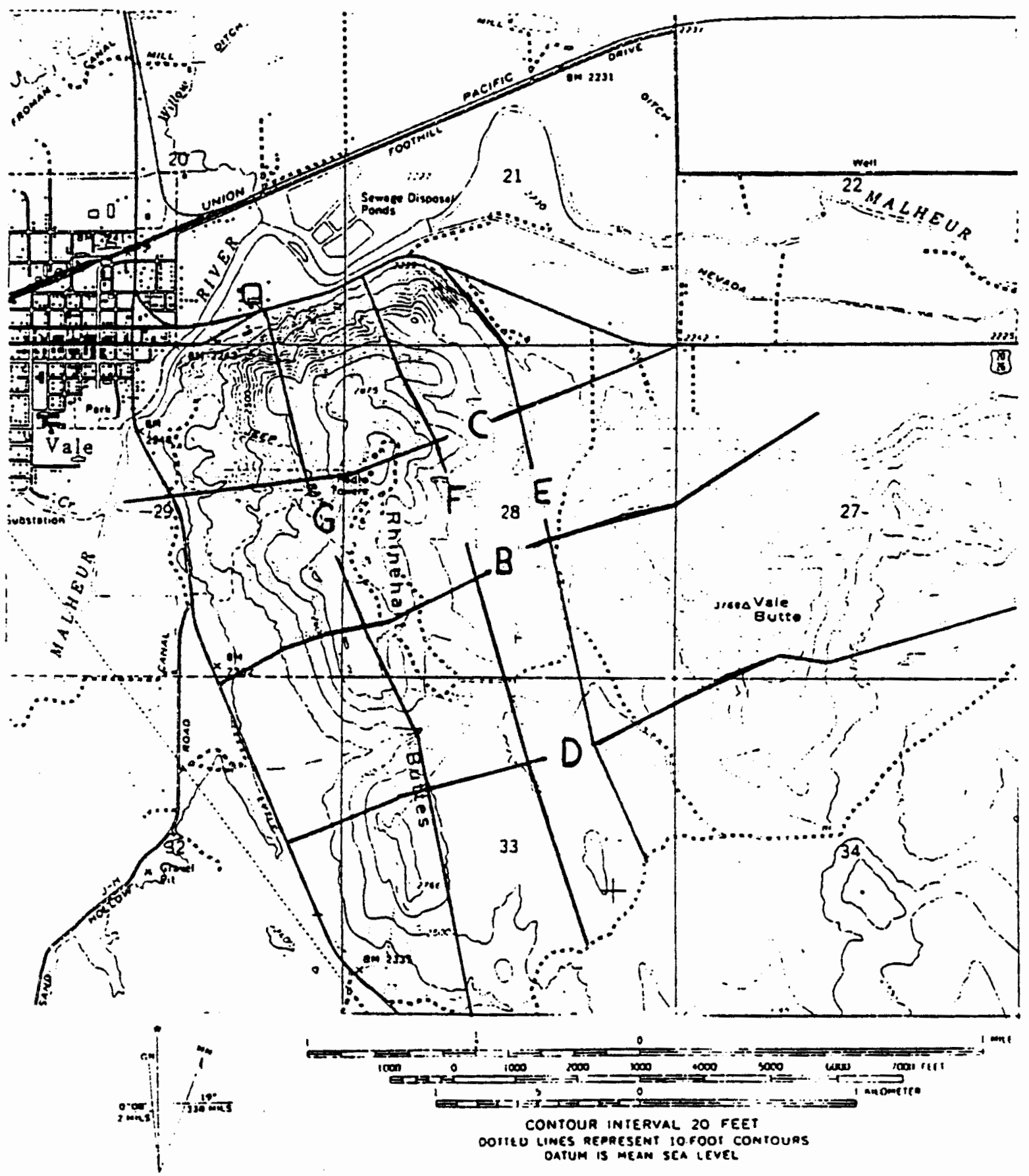

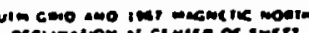

Figure 4. Location and orientation of the magnetic survey grid 
boundaries, the station separation was again expanded to 152 meters $(500 \mathrm{ft.})$.

The lines and stations were established by pace and compass. At each station three readings of the magnetic field were taken to insure continuity and every fifth station within the lease area was flagged and staked with appropriate information. Outside the lease area markers were placed every 76 meters.

Upon completion of the survey, the data were corrected for drift, and profiles for each line plotted. All information was then forwarded to both the main office and to Dr. Meidev for interpretation. The data were then contoured by $\mathrm{Dr}$. Meidev and the interpretations returned to the field crew.

\section{Gravity}

The gravity survey was conducted in April and May, 1981. A similar grid pattern survey was laid out; but the orientation was changed to east-west and north-south, as shown in figure 5. The lines were labeled $A, C$, and $F$ lines in the $E-W$ direction, with $A$ line through the base station. $B, D$, and $E$ lines ran $N-S$ with $B$ line running through the base station. In addition, three lines, $L, M$, and $R$ were on the periphery of the survey grid and were coincident with the other line terminal stations. The gravity base station, which was coincident with the magnetic base station, was tied to the Smithsonian gravity base station at Ontario airport.

Station separation was 76 meters ( $250 \mathrm{ft.}$ ) within the lease area. The separation vas expanded to 152 meters (500 ft.) in the sections 

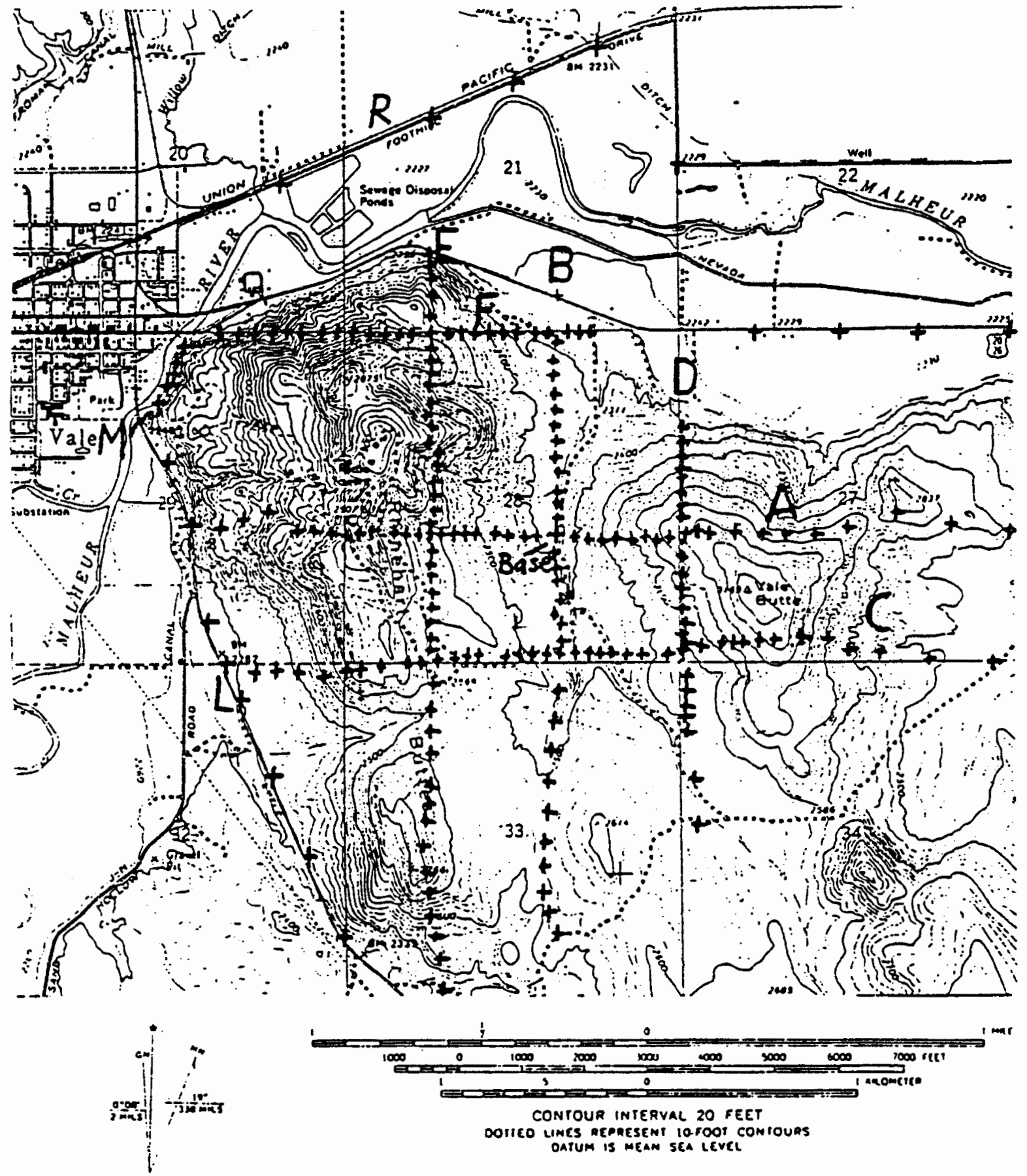

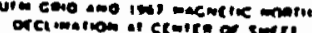

Figure 5. Location and orientation of the gravity survey grid 
immediatly adjacent to the lease boundaries, and expanded further to 304 meters (1000 ft.) on those sections of the lines which were more than an estimated one $\mathrm{km}$ beyond the lease boundary. All peripheral lines had a station seperation of 402 meters.

The readings were taken with a LaCost-Romberg gravimeter. AlI stations were established by pace and compass. Immediatly after the gravity reading was taken, the station was flagged and staked, again with all pertinate information. When recording the gravineter reading also noted was the time and an estimated elevation change in a 30 meter radius; the radius of $B$ ring on the Hammer method of estimating terrain corrections, Hammer (1939). A base station was reoccupied hourly to check for drift.

The surveying was done by Mr. Robert Walston using a laser theodolite E.D.M. The stations were surveyed in immediately after the gravity readings were taken, as part of the gravity reading procedure. There were two bench marks within the lease area, on Vale and Rhinehart Buttes. Most of the gravity stations were visible from these locations. However, it was necessary to establish five secondary instrument stations.

Mr. Robert Walston did the survey reductions and computed the distance to the 44 th parallel for each station. All readings were corrected for drift, and earth tide, Goguel (1954). Latitude corrections were then applied to place all stations on a relative latitude of 44 degrees. Terrain corrections were estimated manually using the Hammer method. The terrain corrections were then modified for use with reduction densities of $2.0,2.1,2.2,2.4, \mathrm{gm} \cdot / \mathrm{cm}$. The 
terrain correction values were modified because, in light of the published geology of the area, the standard reduction density of 2.67 3 $\mathrm{gm} . / \mathrm{cm}$ was expected to be too high. The free air correction factor was also computed. The observed gravity was then calculated using the absolute gravity value from Ontario airport.

The computer program GRAVPLOT Jones (1977) was used to complete the reduction of the gravity data. The GRAVPLOT program when supplied with the station number, station elevation, latitude, terrain correction, and observed gravity calculated the theoretical gravity, free air correction, free air anomaly, and the simple and complete bouguer anomalies, (see appendix A). The program was then modified to calculate the same results using reduction densities of $2.0,2.1,2.2$, 3 and $2.4 \mathrm{gm} . / \mathrm{cm}$. A value of $2.1 \mathrm{gm.} / \mathrm{cm}$ was selected for use in the upper layer, which also matched the value in Lillie (1977) for the uppermost unit in his cross section, shown in figure 6 .

The Portland State University Honeywell computer was used to do the modeling. The program, FREEAIRFIT, which had been previously adapted (Jones (1977), was used to model the Free Air Anomaly. The modeling program, however, considers only a two dimensional cross section. The third dimension is considered infinite and parallel to the strike of the model line. Contributory errors due to terrain not considered in the two dimensional approximation will not be accounted for at this point. In the modeling program the subsurface geology is represented as polygonally shaped blocks of varying density. The . effect of which is calculated at a series of locations on the surface of the model. 

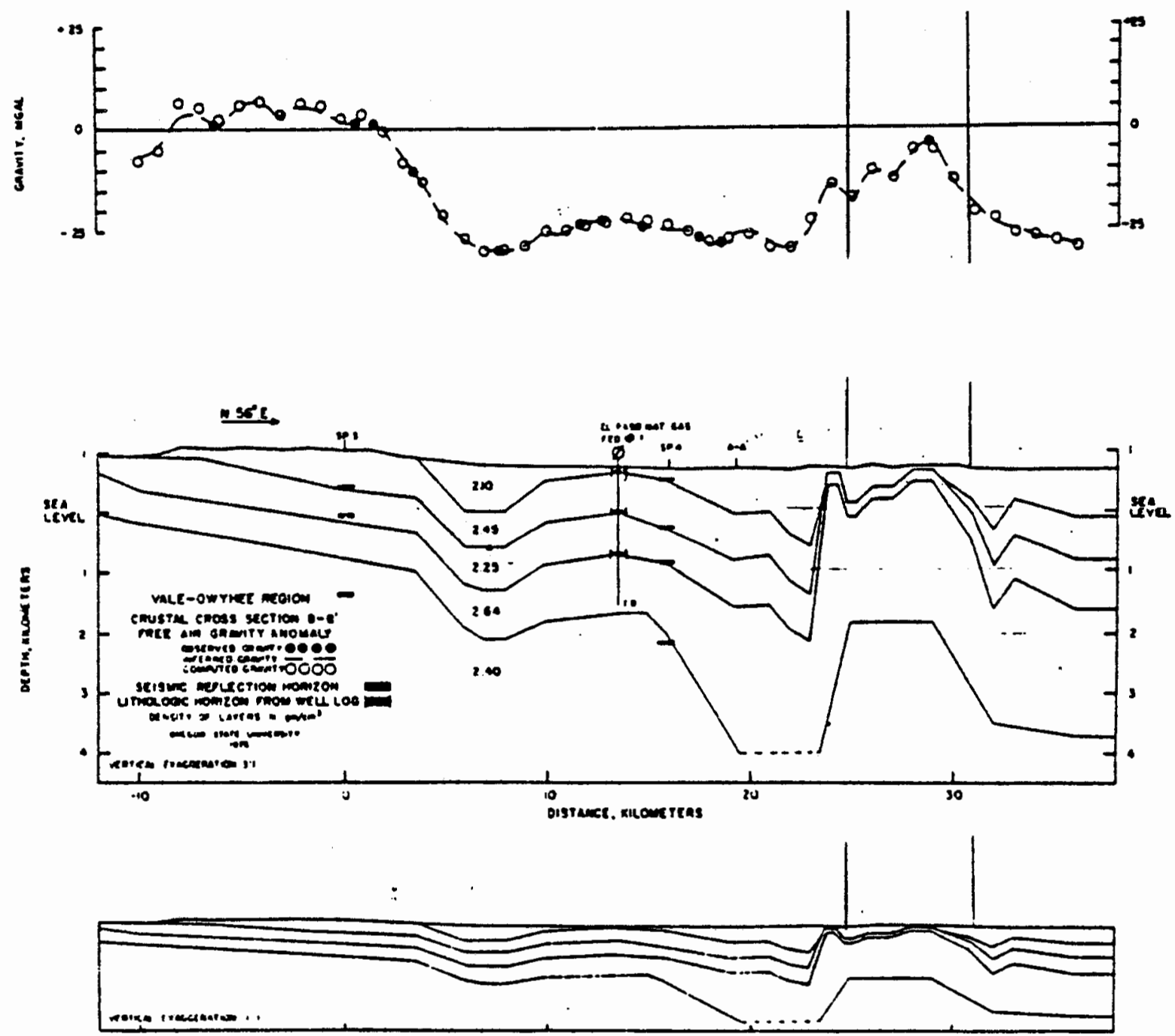

Figure 6. Regional Cross Section along section B-B'. The study area is highlighted in black at the right. Densities shown were used in the modeling program, from Lillie (1977) 
Regional models were constructed which extended 95 to $100 \mathrm{~km}$ from the ends of the survey lines. Two master regional models were constructed, one oriented $\mathrm{N}-\mathrm{S}$ and the other extending in the E-W direction. The regional models were constructed to eliminate edge effects caused by the termination of the model and to account for the gravitational effects of terrain which was not covered by the survey and to duplicate the regional gradients of the surrounding area. The regional Free Air Anomaly map is shown in in figure 7, while the contoured Free Air Anomaly map of the Vale area is shown in figure 8 .

\section{Gravity Modeling}

\section{Results and Discussion}

The initial gravity models were run using a single block. This was done in an attempt to contrast the shape of the anomaly with the topography. The object was to determine which sections of the anomaly would be explained solely by change in elevation. Changes in gravity values are caused by either changes in density or elevation.

The results of the initial model were compared with the profile of the observed anomaly. If the values generated by a section of the model were too high then it would indicate an area whose density value was too high and suggest boundaries of that block, see figures 9 and 10 for examples. The computed value could be reduced by installing a down dropped block. A down dropped block would incease thickness of the 3 upper layer which has a density $2.1 \mathrm{gm} . / \mathrm{cm}$. By increasing the thickness of the volcaniclastic layer the effective density of the column in question would be lessened. This then should indicate 


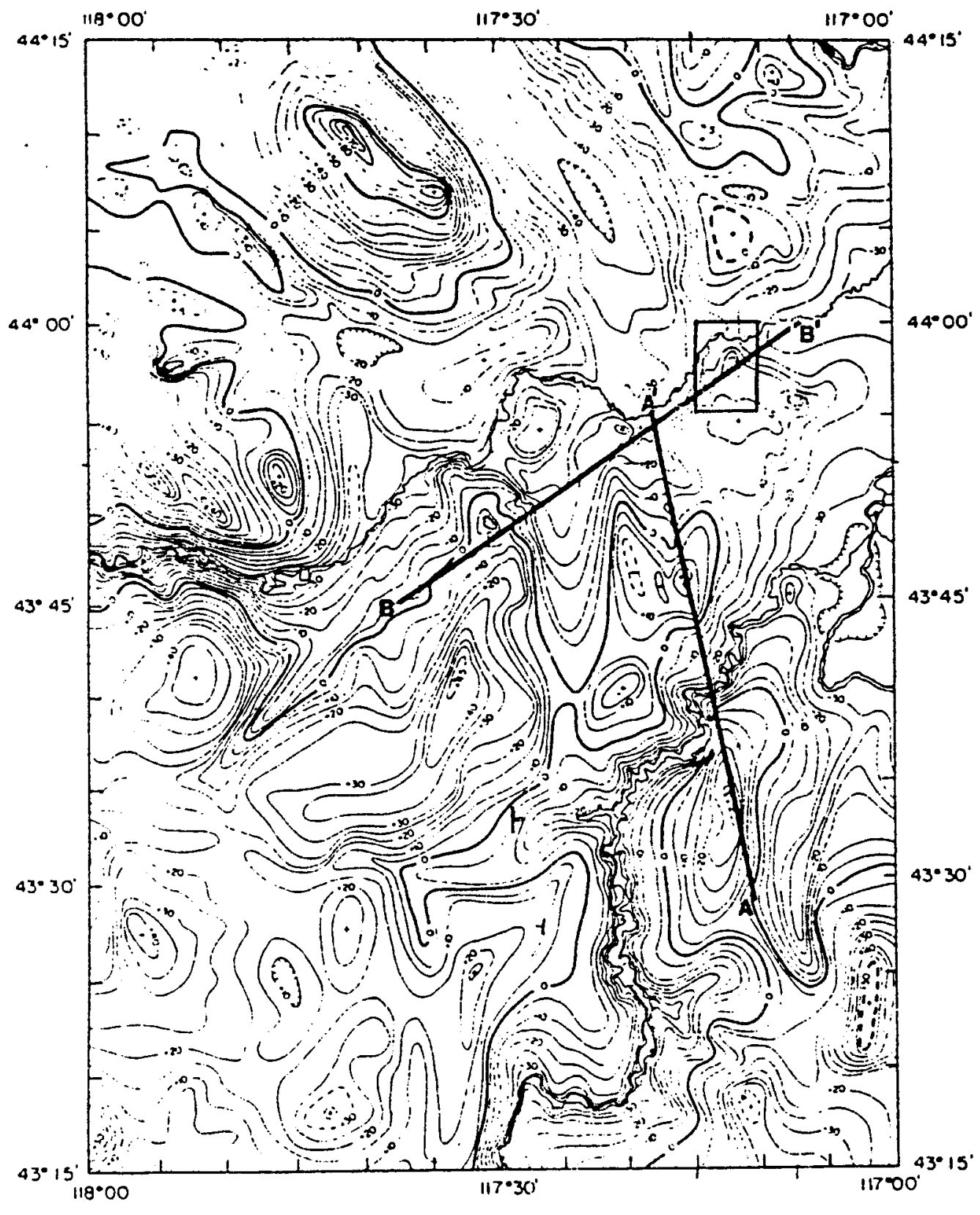

FREE - AIR GRAVITY MAP

VALE - OWYHEE REGION, MALHEUR COUNTY, OREGON

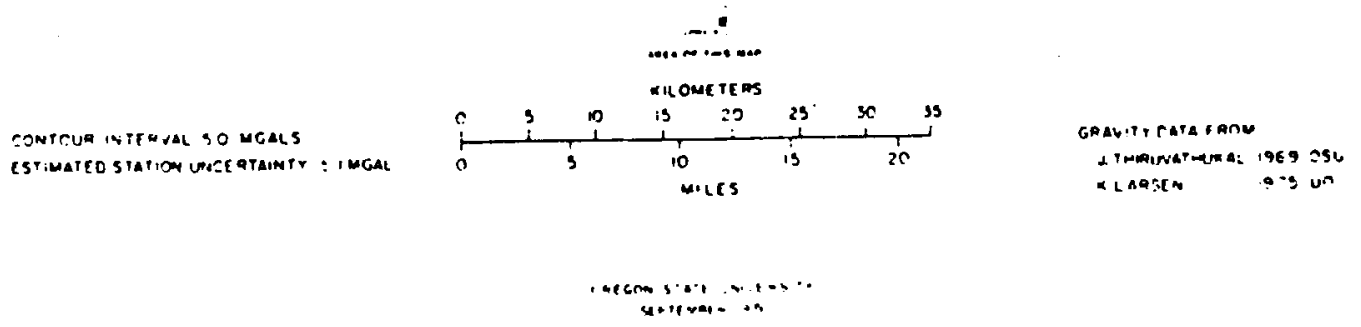

Figure 7. Regional Free Air Anomaly Map. The study area is outlined in black in the upper right, from Lillie (1977) 


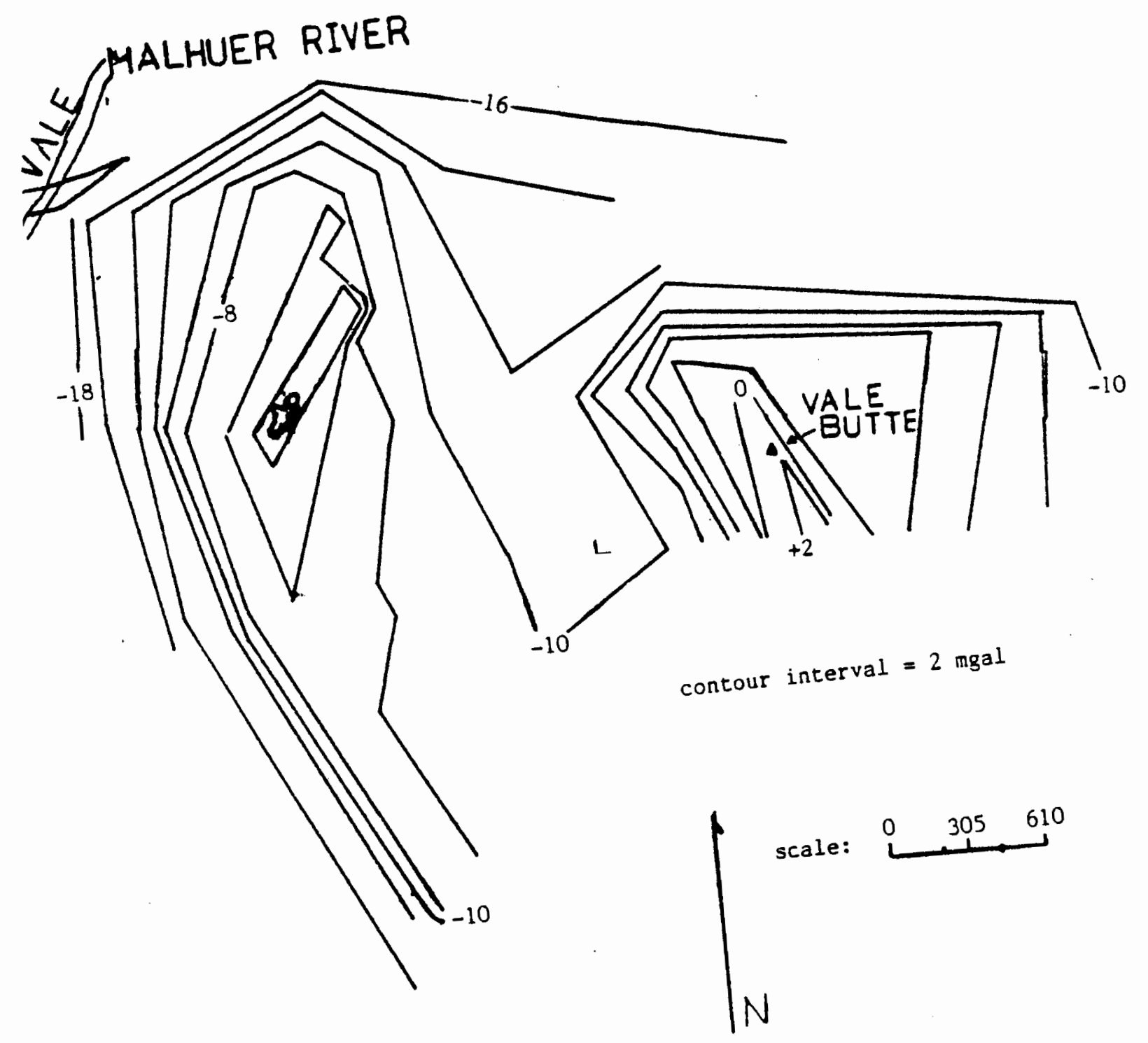
Figure 8 . Contoured Free Air Anomaly Map of the Vale Area. The town
of vale is located at the upper left corner. 
direction of movement while the magnitude would be determined by the depth of the block boundary. In some cases this offset should indicate depth to a depositional contact. This instance is valid in areas where landslides and recent alluvium is being modeled.

Changes in the model that would require an increase in density could be explained two ways. Either a structural block could have been uplifted, increasing the average density of the block by thinning the low density layer at the surface, or there was an in situ increase in the density of the block. The in situ increase in density might occur in areas that were mapped as silicified zones. In areas of silicification the country rock is flooded and recemented with silica, given a density of $2.7 \mathrm{~g} / \mathrm{cm}$ in Telford et al (1976). This filled the available pore space, resulting in an increase in density of the rock.

The survey area was bordered on the western through the northern sides by the Malhuer River flood plain. These areas layer of low density, unconsolidated, recent alluvium is deposited upon the older layers. The alluvium of the flood plain was assigned a density of 2.0 3 $\mathrm{gm} / \mathrm{cm}$, an average value for recent alluvium from Teleford et al (1976).

The following modeling procedure was and used on each of the survey lines. The initial model contained only one layer of density 3

$2.35 \mathrm{~g} / \mathrm{cm}$. Changes that were made to that model were done in the simplest format possible and then changes of increasing complexity were made only as required. The simplest changes were using rectilinear blocks, with vertical and horizontal block boundaries. If the fit was sufficient then no other changes were made. If more complex shapes were 
required then shapes were evaluated in $15^{\circ}$ increments from the horizontal or vertical, and the best fit solution was then adopted. At this point of the modeling it was not attempted to relate the model to the geology. In some areas, field evidence suggested that a more sophisticated shape should be used, but if the fit using the rectangular blocks were good, then no changes were added. Although the rectilinear blocks may fit the gravity data, the actual surfaces are usually dipping a few degrees from horizontal and vertical. On larger blocks, with long dipping surfaces it was necessary to account for the dipping surfaces.

\section{A $\underline{\text { line }}$}

The initial modeling was done on A line, see figure 9 because the structures crossed by this line were thought to be located most precisely. The line was oriented in an east-west direction and included the gravity base station, which was shared with the $B$ line. The line is composed of 44 stations, labeled AE 1 through AE 20, AW 1 through AW 23 and the base, the data is displayed in appendix. A. A" line also intersects both $D$ and $E$ lines at stations $A E-9$ and $A W-9$ respectively. Elevations ranged from a low of 683.51 meters at $A W 23$, in the town of Vale, to a high of 900.26 meters at $\mathrm{AE} 11$ on the north side of Vale Butte. The total length of A line was $5.4351 \mathrm{~km}$. The Free Air Anomaly (FAA) values for A line ranged from a low of -23.472 mgals at station $A W-23$ to a high value of $-0.578 \mathrm{mgals}$ at AE-12. The teriain corrections used ranged between 0.016 and 2.600 mgals. 
The survey line ran from AW 23 eastward across the alluvial plane of the Malhuer River across Rhinehart Buttes, the west flank of which is covered by a large landslide deposit. The eastern portion of A line continues across Vale Butte with the line terminated in the valley east of the Butte.

The result of the initial one layer model is shown in figure 9.. Changes are needed except at the center of the line. The center of the line was chosen as acceptable because the greatest number of stations closely matched the values of the observed gravity. There were thus less changes to model and to allow easier comparison with B line. The changes to the model will be described from west to east.

The values calculated for the model were $2.33 \mathrm{mgals}$ to $2.35 \mathrm{mgals}$ too high in the area of the Malhuer River alluvial plain. The flood plain sediments were modeled using a value of $2.0 \mathrm{gm} . / \mathrm{cm}$. A density contrast of $0.35 \mathrm{gm} / \mathrm{cm}^{3}$ is generated, and the required depth found to be a range of 200 meters to 218 meters, as shown in figure 10. The length of the block is $3.0236 \mathrm{~km}$. If the density of the sediments is less, than the thickness of the alluvium will decrease correspondingly.

The next change to be instituted was at the location of the landslide deposit on the west slope of Rhinehart Buttes. The landslide deposit is composed of large blocks of silicified rock in a matrix of country rock debris. The deposit itself is very poorly consolidated. 3

A density of $2.1 \mathrm{gm} / \mathrm{cm}$ was assigned. The apparent lack of lithification suggests that a density of less than $2.1 \mathrm{gm} / \mathrm{cm}^{3}$, the density of the country rock, should be used. However, the presence of extremely large, dense, blocks of the altered rock could offset the 


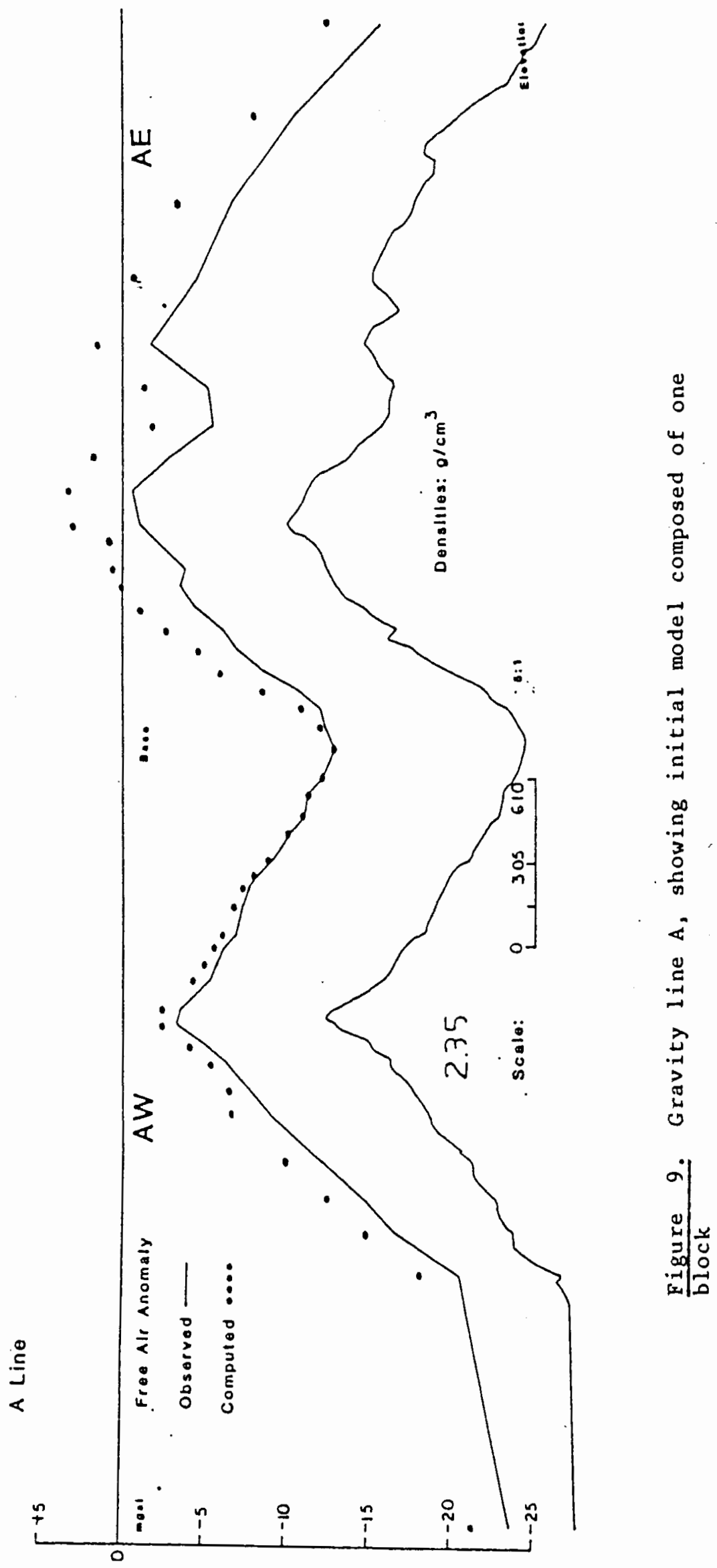




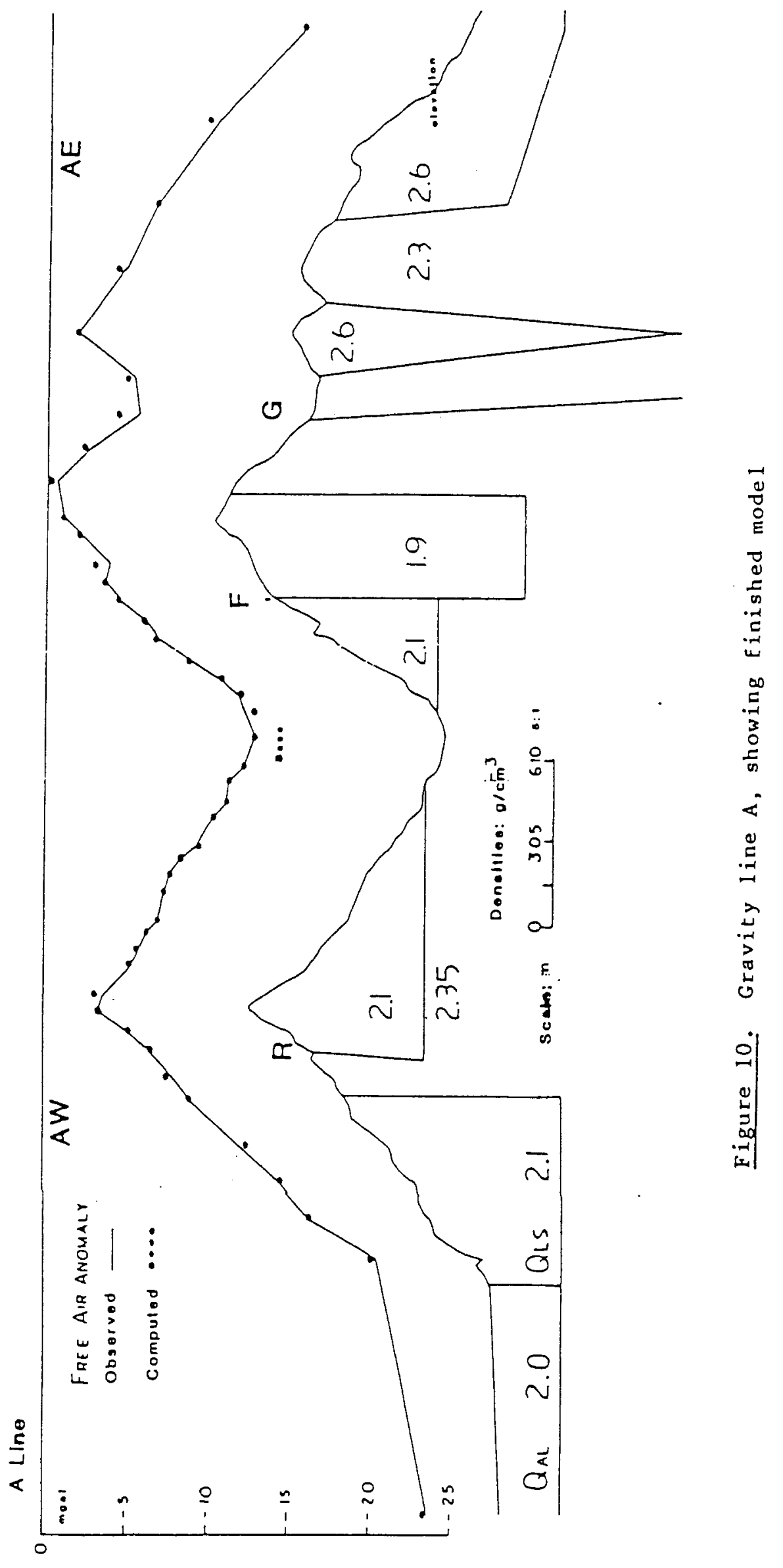


apparent decrease in density of the deposit. The locations of the contacts or margins of the landslide had been mapped geologically, so the block boundaries were based on this information.

When compared to the observed anomaly on the west of Rhinehart Buttes the initial model indicated too high a value. The differance ranged from 1.60 mgals, on the western edge of the block, to 2.27 gals, near the eastern margin. The thickness of the block was solved by trial and error with the best fit obtained with the base of the landslide block at an elevation of 482.9 meters. The landslide block has a thickness which ranges from 200 meters to 313.3 meters and a length of 664.9 meters. There still are some one point anomalies that have not been corrected. It is felt that these are probably the result of older topography which was buried by the landslide. As the base of this deposit was modeled as a straight, smooth surface any buried topography, which may be a buried density contrast, would manifest itself as an anomally in the calculated effect of the model.

The values to the east of the landslide block were still slightly too high, approximately $0.5 \mathrm{mgal}$, and increased rapidly from the location of Rhinehart fault, to a maximum of 1.18 mgals at AW 13 on the crest of Rhinehart Butte. The values then decrease until matching the observed at station AW 2. The first to model this block used was a block with a horizonal lower boundary, beginning at station AW 2 and continuing westward. The elevation was the same as AW 2, 730.42 meters. The western boundary was the crest of Rhinehart Butte. The initial model did not fit the observed anomaly. A series of changes were instituted until a fit was achieved. The simplest solution was a 
steeply dipping, 75 degrees, western block boundary. This boundary coincided with the mapped location of Rhinehart Fault. The final configuration is a roughly triangular shaped block with the west face dipping 75 degrees and a thickness of 85.4 meters which increases to 134.2 meters at the crest of Rhinehart Buttes and then tapers to zero meters in height. The length is 1044.3 meters.

The fit of the model was good from station AW 2, located on the east side of Rhinehart Butte through the base. The section of AE line, from the base station to the crest of Vale Butte was examined next. The model was again too high. The values ranged from matching the observed at base to a high of being 4.03 mgals over at AE1l. The differance in the values seemed to increase with the change in elevation. A similar situation was encountered in modeling the previous block

The same procedure was used as in the previous block used. The values calculated for the model ranged from being too low, $0.34 \mathrm{mgals}$ at $\mathrm{AE}$ 1, to being 4.03 mgals too high at $\mathrm{AE} 11$. The first model placed the contact at station AE 2 and the lower block boundary was horizontal at that elevation. The result was that the model was still too high and the contact establjshed at a block corner between stations $A E 1$ and $A E$ 2. The lower block boundary was horizontal at an elevation of 731.7 meters that resulted in a block whose dimensions were a height of 113.6 meters with a length of 408.7 meters. Station AE 1 remained too low. A series of vertical and later dipping dike like bodies, density $2.7 \mathrm{gm} . / \mathrm{cm}$. were installed to bring up the values at that location. The values for $\mathrm{AE} 1$ were brought up to match the observed, however the adjoining stations were then too hich. There remains a 
small difference in elevation between the two blocks of the upper unit which lie in close proximity to each other. This could be the result of the regional dip, which is to the northeast. Alternatively it could also be the result of a structure which lies between the two blocks. This structure could be masked by a section where strike-slip movement has eliminated a density contrast. This last explanation, however, seems unlikely in view of the fairly large amounts of vertical offset generated in adjoining sections of the fault systems. The fit between the model and the observed was acceptable only for stations $A E 2$ through AE 5. The fit of the portion of the line between AE 6 and and $A E 11$ was still too high. The differance was $0.6 \mathrm{mgals}$ at $\mathrm{AE} 7$ and $1.12 \mathrm{mgals}$ at $\mathrm{AE} 11$.

To generate the needed density contrast and still maintain the 3 estimated throw of the block a density of $1.9 \mathrm{gm} / \mathrm{cm}$ was used. The lower boundary was established at an elevation of 631.7 meters. The magnetic modelling, however, suggested a deeper seated structure at that location. If a value of $2.1 \mathrm{gm} / \mathrm{cm}$ were substituted, the block would have to be thickened. The lower boundary at that density is calculated to be at an elevation of 519.7 meters, which agrees with the results of the magnetic modeling. The section would then have a length of 359.9 meters and a maximum height of 380.6 meters.

The section of A line, from AE 14 through AE 20 was also too high. The values calculated for the one layer model indicated, at least at $\mathrm{AE}$ 17 to be $3.53 \mathrm{mgals}$ too high. After several unsuccessful attempts using small surficial blocks, a larger, deep seated block as suggested by Lillie (1977) as shown in figure 6, was used. To decrease the 
3

values the appropriate amount a density of $2.3 \mathrm{gm} / \mathrm{cm}$ was used. The block was extended to a depth of 2,300 meters. The fit was at some locations satifactory, while at others it was less so. Stations $\mathrm{AE} 17$, $A E 19$, and $A E 20$ were by comparison still far too low. Station $A E 17$ was 4.56 mgals too low while the other two were less.

The area of station $A E 17$ was mapped as a silicified zone. To achieve the needed amount of increase in density to raise the calculated value for the station a high density wedge shaped block was used. A wedge, with the apex beneath the station would effectively increase the mass while still acting as a point source. A density of 3

$2.6 \mathrm{gm} / \mathrm{cm}$ was assigned on the basis that the rock consisted of, for modeling purposes, pure silica.

Various depth and width combinations were tried and the best fit was a wedge 254.0 meters across and 342.4 meters deep. The wedge was centered under station $A E 17$ and none of the boundaries extended as far as the neighboring stations. The inverted triangular shape is not be a common geological occurrence, however.

The last two stations of $A$ line $A E 19$ and $A E 20$ were modeled in the same way as the previous block. The amount of correction required was determined and the shape necessary to achieve the best fit was achieved by trail and error method. Because of the large block of 3 dense, $2.6 \mathrm{gm} / \mathrm{cm}$, material required and the nature of the structure of the silicification zones, which display a tendency to be linear features, it is believed that the zone under stations $\mathrm{AE} 19$ and $\mathrm{AE} 20$ is probably quite narrow and sub parllel to the survey line. The final configuration of the block was approximately wedge shaped having 
maximum dimensions of 200 meters in thickness and 1084.6 meters in length.

\section{B Line}

B line was the second line to be modeled. The line ran northsouth in the valley between Vale and Rhinehart Buttes. B line, as shown in figure 11, consisted of 34 stations including the base, which was shared with A line. Like A line it was divided into two segments, BN and BS, at the base station. BN ran north of base and consisted of 14 stations. BS ran to the south and consisted of 19 stations. The elevation profile was lowest in the north and generally increased in elevation to the south. The elevations ranged from a low of 680.92 meters at BN13 to a high of 770.87 meters at BS 15 . The FAA values ranged from a low value of -17.677 mgals at station $B N-10$ to a high of -9.049 at BS -15 . The terrain correction values for B line ranged between 0.061 to $0.549 \mathrm{mgals}$.

The same modeling procedures were used on B line as were used on A line. An initial model consisting of one block was used first. The one block model, shown in figure 11, revealed an excess of mass on the alluvial plain, and several locations which could be considered to display either an excess of mass or alternatively, adjoining areas which were mass deficient. Both alternatives were considered.

The modelling proceeded from north to south. As was done with A line the block representing the unconsolidated alluvium was the first 3

step. A value of $2.0 \mathrm{gm} / \mathrm{cm}$ was used to represent the alluvium. The comparison indicated a difference of three mgal between the measured 


\section{B Line}

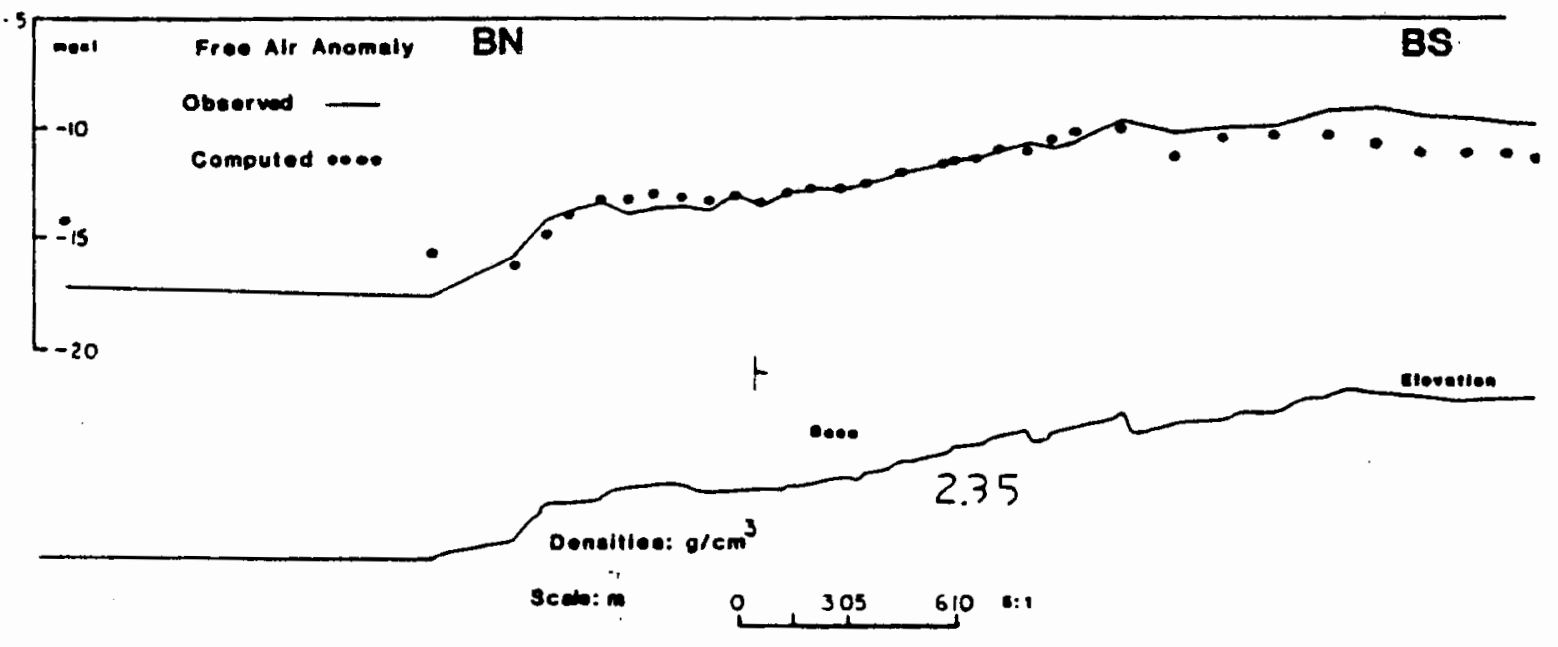

Figure 11. Gravity line B, showing initial model, composed of one block 
and the observed. A block was modeled with a depth to the bottom of the block of 258 meters.

Because of the evidence of silicified zones close to B line it was decided to incease the density of those areas to raise the value of the computed gravity, shown in figure 12. Twenty meters south of station BN 12 a vertical dike like body of silicified rock, density $2.6 \mathrm{~g} / \mathrm{cm}$ was instalied. This block was 20 meters wide and was 442 meters deep. The addition of this block brought the value calculated for the model up to match the observed values, but would necessitate the placement of a low density body adjacent to it to the south.

As was done with A line, a block was described which would reduced 3 the values to match the observed. This block, density $2.1 \mathrm{gm} / \mathrm{cm}$ was also bounded by vertical contacts with a width of 396 meters and a depth of 123 meters. This block was in the area of stations BN 4 through BN 9. The fit was good for the rest of the 1 ine through station BS 11 .

At the location of station BS 11, the values of the one block model indicated another mass deficiency. The calculated value was 2.11 mgals too low. The addition of a block, density $2.7 \mathrm{gm} / \mathrm{cm}$, which was vertical and was 220 meters wide and 500 meters deep emplaced the correct amount of mass.

B Iine was then done using the technique of reducing the inass in those places where the calculated values were too high, as shown in figure 13. The block inserted was $2.0057 \mathrm{~km}$. Iong and had a thickness of 48.3 meters. The block of simulated alluvium reduced the calculated values the required $0.56 \mathrm{mgals}$. 


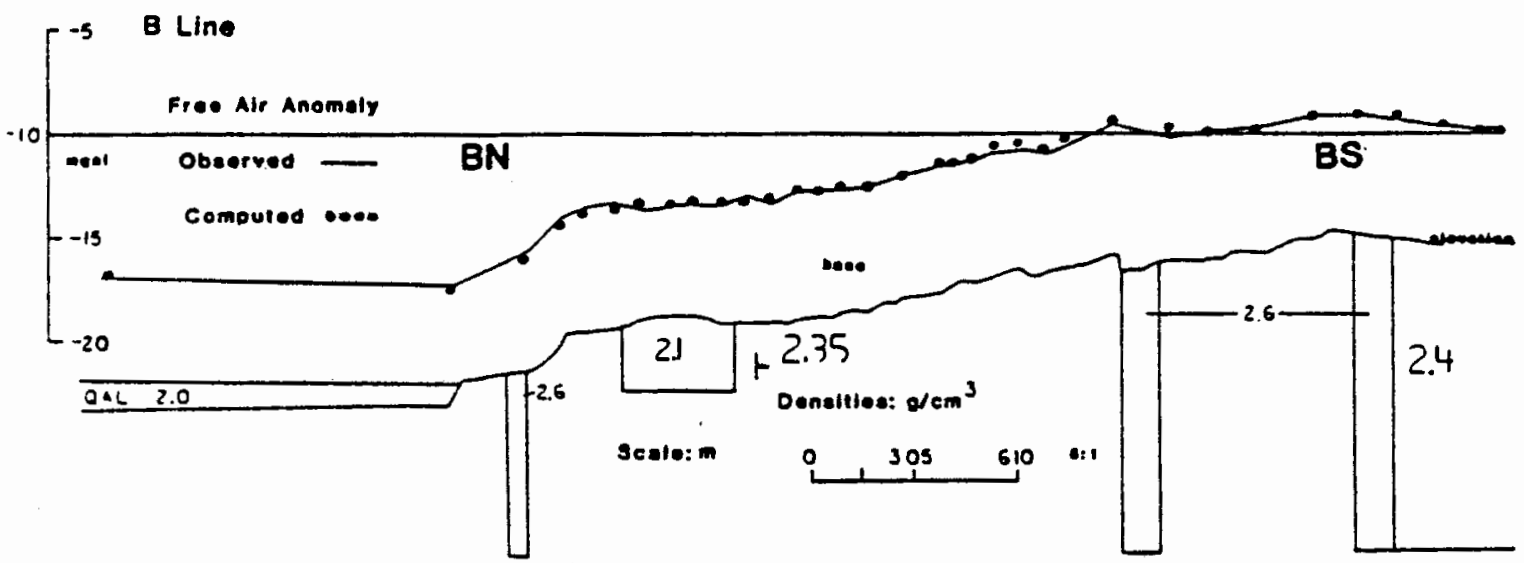

Figure 12. Gravity line B, showing the finished model of the mass deficient interpretation 


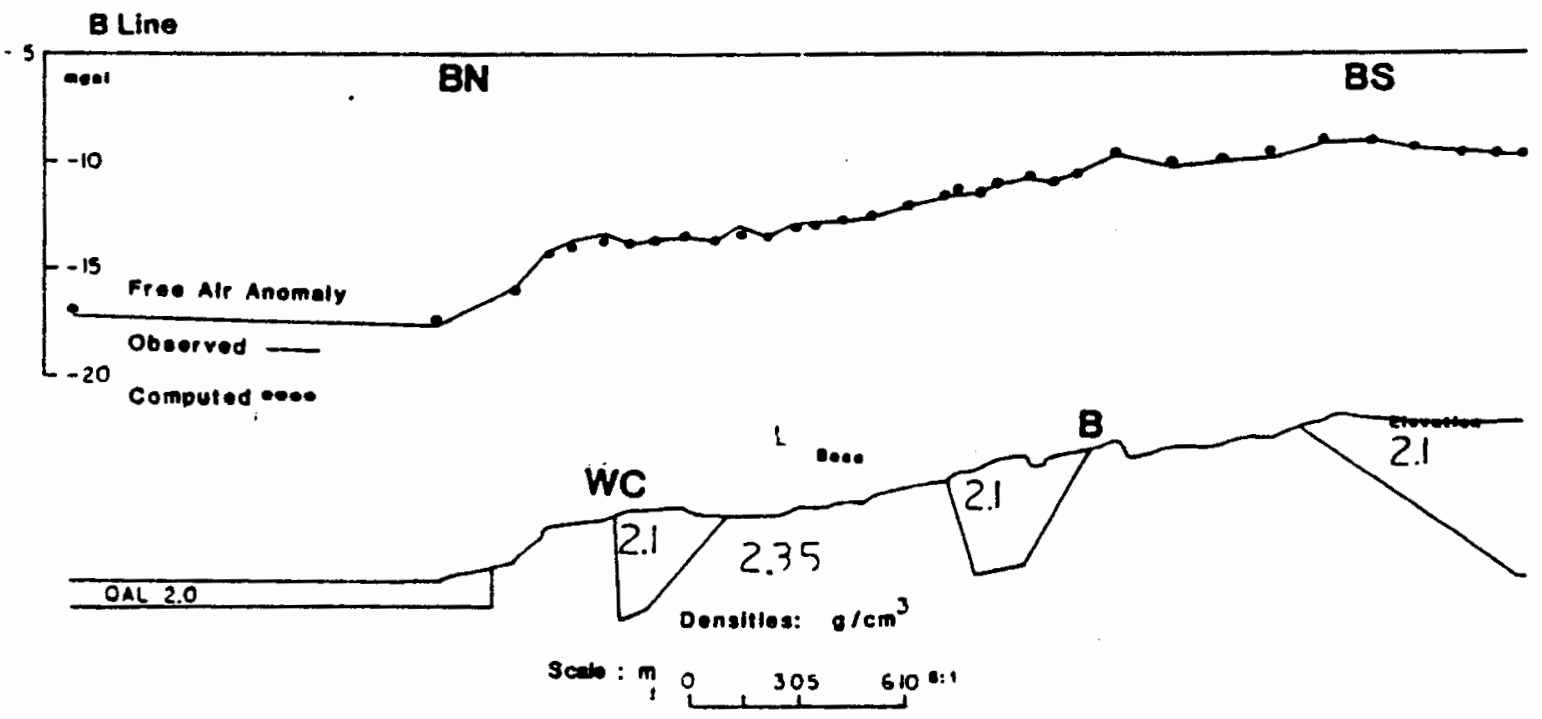

Figure 13. Gravity line B, showing the finished model, showing the preferred excess mass interpretation 
The next location to be adjusted was a high that ran from BN 4 through BN 8. This location deviated from the observed by a maximum of $40 \mathrm{mgals}$. The block was as a wedge shaped configuration, with a density of $2.1 \mathrm{gm} / \mathrm{cm}^{3}$. The thickness ranged from zero at the edges increasing to a maximum of 120 meters somewhat north of the center of the block. The overall length is 306.7 meters.

The next area was located between stations BS 4 and BS 10 . This area was a maximum of $2.0 \mathrm{mgals}$ high. Using the same method as the other locations resulted in a block 60 meters thick, having both the north and south contacts dipping inward to meet a gently northward dipping lower boundary. The maximum depth was at an elevation of 749.0 meters. The resulting length of the block was 414.8 meters. The final area on $B$ line that required adjustment was the southern end, consisted of the last six stations, BS 14 through 19. This section indicated a maximum variation at station BS 19 . The variation was 1.05 mgals too high. A southward dipping wedge was inserted, having a maximum thickness at the location of BS 19. The thickness is 90 meters, at an elevation of 679.2 meters.

The format established on A and B lines was used for the rest. All the 1 ines all contained segments which were located on the Malhuer River floodplain, which extended around both the western and northern was assigned. On the rest of the lines an upper layer of volcaniclastics with a density of $2.1 \mathrm{gm} / \mathrm{cm}$ was used, where needed. The remaining four 1 ines will be described in terms of the finished 
model rather than the corrective steps to achieve the fit to the observed gravity.

\section{Interpretation}

\section{A $\underline{\text { line }}$}

The configuration of the finished model is shown in figure 10. The sections in the western parts of the model have already been discussed earlier. It may be noted due to a number of reasons that the area of recently alluvium is certainly shallower than depicted in the model. Some of the reasons may be that the alluvium has a density less than the assigned value, or there may be a layer of density $2.1 \mathrm{~g} / \mathrm{cm}$ overlying the lower layer. This occurrance would have certainly made the layer of recent alluvium in the model much thinner. In the area around Rhinehart fault, marked $R$ on figure 10 , suggests a steeply westward dipping reverse fault. The interpretation suggested is that Rhinehart Fault is a westward dipping normal fault, with the increase in density on the western side of the model provided by silicification. Field evidence suggests that this interpretation may be valid. The area west of the fault is composed of silicified country rock, while the area to the east displays very little silicification. The section between Rhinehart Fault and the landslide deposit is a third composite unit. The average density of which happens to be $2.35 \mathrm{gm} / \mathrm{cm}^{3}$. It consists of a mixture of volcaniclastic sediments and dense silicified country rock. 
The section of A line located just east of the base may be interpreted as a section of the volcaniclastic sediments which has not only been truncated by a fault, marked as $F$ on figure 10 , but also offset by a second fault, along a different trend. Alternatively, the area modeled, in light of field data is a complex intersection of faults, consequently because of the possibility of a highly fractured area the effective density may be as 10 as $1.9 \mathrm{gm} / \mathrm{cm}^{3}$.

To the east, the next section to be interpreted is the downward wedge. From field mapping, the area around station AE 16 is composed of silicified conglomerate beds, with a large areal extent above a siltstone unit. The siltstone units have low permeability and consequently the alteration zones are very narrow. The block could represent a narrow feeder zone of silicified silstone which is capped by conglomerate with silicification of a much larger horizontal extent. The actual configuration may be likened to a $T$. But, for the model a downward pointing wedge has matched the coputed values with those of the observed.

East of the wedge location is the regional scale boundary fault, shown as fault $G$ on the figure. Brown, 1982, reports that at the location in question is a normal fault which is downthrown to the west. The down to the west is the opposite interpretation of Lillie, 1977, see figure 6, or field evidence, in this report. If the structure were down to the west, perhaps the offset would be sufficiently large enough to raise the Grassy Mountain Basalt to generate a density contrast and increase the density of the block in question. 


\section{B Line}

The northern portion of $B$ Line is modeled as relatively thin layer of alluvium. Although there are a number of wells in the immediate vicinity, the logs were not helpful. Either the wells did not penetrate beyond the alluvium or those that did the depth of the horizon was not noted. In figure 13 the initial block modeled, to the south of the alluvium is a wedge of upper layer volcaniclastics. This wedge shaped block was interpreted as being bounded by fault planes, marked as faults $W C$ and $E$ on figure 13. The low angle of the dip of the block boundaries is probably due to the intersection of $B$ line and the fault planes at an oblique angle. The closer the angle of intersection between the survey line and a boundary plane is to $90^{\circ}$, the steeper dip, and the closer the boundary plane approximates the actual dip of the fault plane. Another possible interpretation is that the block is actually a landslide deposit, and it could have a density somewhat lower than the value used in the model. In that case the deposit would be slightly thinner than the block shown in the model.

The next block to the south is another graben. The downdropped block is bounded by the faults marked as A and B on Plate I and figure 13. These two structures also occurred on $\mathrm{C}$ Line and the magnetic models as well as being identified in the field mapping portion. The southernmost portion of $B$ Line is another apparently downdropped block of the upper layer. However, the interpretation of this block is ambigous, with several possilble, equally valid explanations. The first and most obvious is that the block boundary 
represents another oblique intersection of a fault plane. However in this particular area B line crosses a small area of recent alluvium, and poorly consildated Pliocene sediments. If these deposits are less 3

dense than the $2.1 \mathrm{gm} / \mathrm{cm}$ value assign the thickness of the block will be correspondingly thinner. A third possible explanation is that the block represents a combination of both of these events.

\section{C $\underline{\text { line }}$}

C line is an east-west 1 ine located about 300 meters south of $A$ line. Elevations range from a low of 684.79 meters, in the west to a high of 927.51 meters at Vale Butte. It is composed of 46 stations; C0 which is coincident with BS-9 and CE section with 22 stations and the remaining 23 in $\mathrm{CW}$ section.

The initial models of the western edge of $c$ line indicated a simple flat bottomed fill of recent alluvium would not match the observed gravity. Only four data points were located on the area of recent alluvium. The structural interpretation developed by Lillie (1977) was used. The model suggested that the floodplain was underlain by a segment composed of small scale horst and graben stucture. This solution satisfied the requirements of the model. The depth requirement for the recent sediments was calculated for each individual point and then integrated into the model as a whole. Older topography, which was buried by the Malhuer River sediments may account for the configuration of the terrain beneath the sediments. The block of recent sediments, alluvium and coluvium, extends westward to the base of Rhinehart Buttes. From that location extending to the east, is a layer of low 
density material, that has been faulted by a series of normal faults. Field work suggests that the area is crossed by a number of normal faults. These faults are small scale horst and graben extensional type faulting.

The model of C line, shown in figure 14, consists of one block of low density material, in the western portion. To the east it contains three blocks of volcaniclastics, and the eastern segment is one block of high density material set into the lower layer. The country rock, 3

density $2.35 \mathrm{gm} / \mathrm{cm}$, extends from beneath the floodplain to the east, rising to meet a low density block of volcaniclastics at the location at which the recent sediments end. This would suggest that a normal fault, downdropped to the east occurs at this location, This fault is identified as $H$ on figure 14 and Plate I. If the thickness of the recent sediments were to be more than the assigned value then to match the observed gravity at that location an increase in density of the underlying rock would be necessary to compensate for reduction in overall density for the column at that location.

From the margin of the recent sediments eastward 450 meters to the east flank of Rhinehart Butte is a block of volcaniclastic sediments which is downdropped relative to the block adjacent to the east. The location of the eastern block boundary does not agree with the field mapping location of the Rhinehart Fault, which is exposed in that location. The block boundary in the model, labelled $R$ in figure 14 is located about 100 meters east of the Rhinehart Fault. This may be due to the presence of a narrow zone of silicification that occurs along the Rhinehart Fault trace at this location. The offset, suggested by 


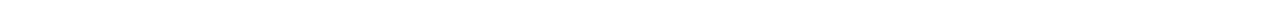


the model is about 50 meters, along a vertical boundary. The upper block east of the Rhinehart Fault continues to the east about 390 meters. The block boundary is again vertically downdropped approximately 60 meters relative to the block to the east. The fault at this location is labelled as A. The next block to the east extends about 360 meters. This block is composed of the lower combined layer of density $2.35 \mathrm{gm} / \mathrm{cm}$. This block is bounded on both the east and west by blocks of the $2.1 \mathrm{gm} / \mathrm{cm}^{3}$ volcaniclastic upper layer. $\mathrm{C}$ line to this point appears to be described as two en echelon normal faults that are down to west, followed by a horst block which is bounded on the east by a normal fault which is down to the east, shown in figure 15 . The offset measured on the model is about 60 meters. Field mapping compliments the modelling as to the location of the this boundary, which appears to be a fault. However, the offset may be less than the 60 meters predicted by the model. The next eastward block is a block of volcaniclastics about 420 meters in length. It is bounded on the west by the previously described horst block and on the east by a vertical boundary. The vertical contact is believed to be another normal fault which is down to west, identified as $B$. This would describe a small graben, complimenting the horst which lies to the west. This normal fault has been refered to as the southern extension of the Willow Creek Fault by Brown (1982) and trends to the northwest and lies just west of Vale Butte, marked WC. The Willow Creek Fault is westward dipping normal fault, which in the model displays an offset at this location, of approximately 55 meters. To the east of the main Vale fault is a long block of 810 meters which includes all of Vale 


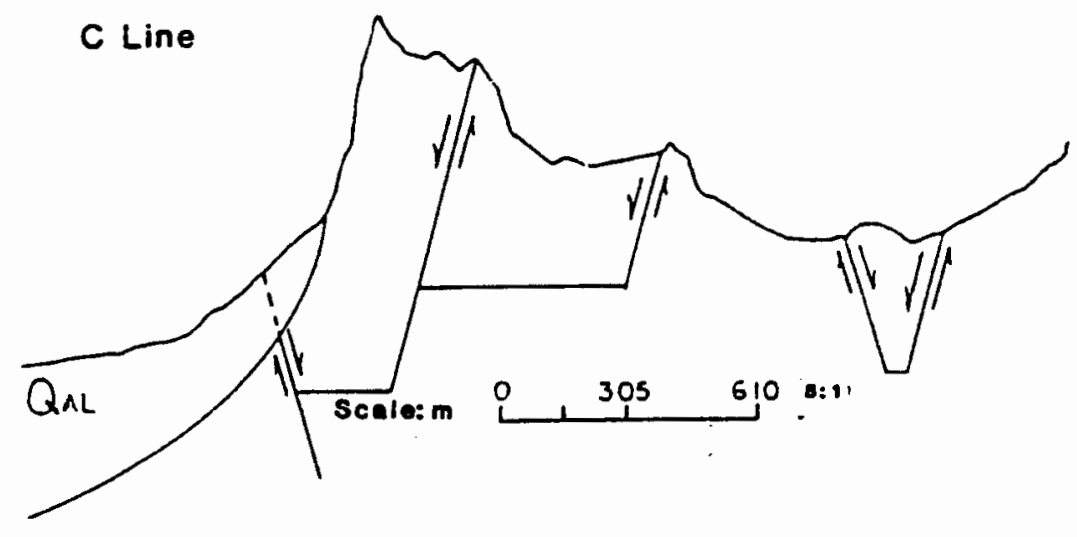

Figure 15. The interpretation of the model of $\mathrm{C}$ gravity line 
Butte. The block is terminated as an eastward dipping contact located on the eastern margin of Vale Butte. From this structure westward the model suggests an upper layer of low density volcaniclastic material which extends across the lease-study area. This layer of volcaniclastic material has been faulted and offset since deposition during the Pliocene. The layer becomes progressively thinner from the west until it is faulted out at the small horst block. At that point the structure changes from en echelon down to the west normal faults to horst and graben type structure.

The last block on $C$ ine is composed of high density, $2.6 \mathrm{gm} / \mathrm{cm}^{3}$, material. The interpretation of this large mass is that there may be a dike like silicification zone extending subparallel to $c$ line. The area coincides roughly with the eastern section of A line.

\section{Line}

The D line is a north south line which runs parallel to the A 1ine. It is located about 300 meters east of A line and follows the section line between sections 27 and 28 along the west flank of Vale Butte. The model of the D.line, shown in figure 16, consists of one block of low density material in the north, with one block of volcaniclastics in the center of the line and the south end has one block of slightly higher density material. To the north the area is recent sediments which are deposited on the lower layer of the model. From the contact at the south end of the floodplain lower layer is exposed. From the crest of Vale Butte to a point 300 meters south is a small block of the upper volcaniclastic unit. It is bounded on the 


\section{$D$ Line}

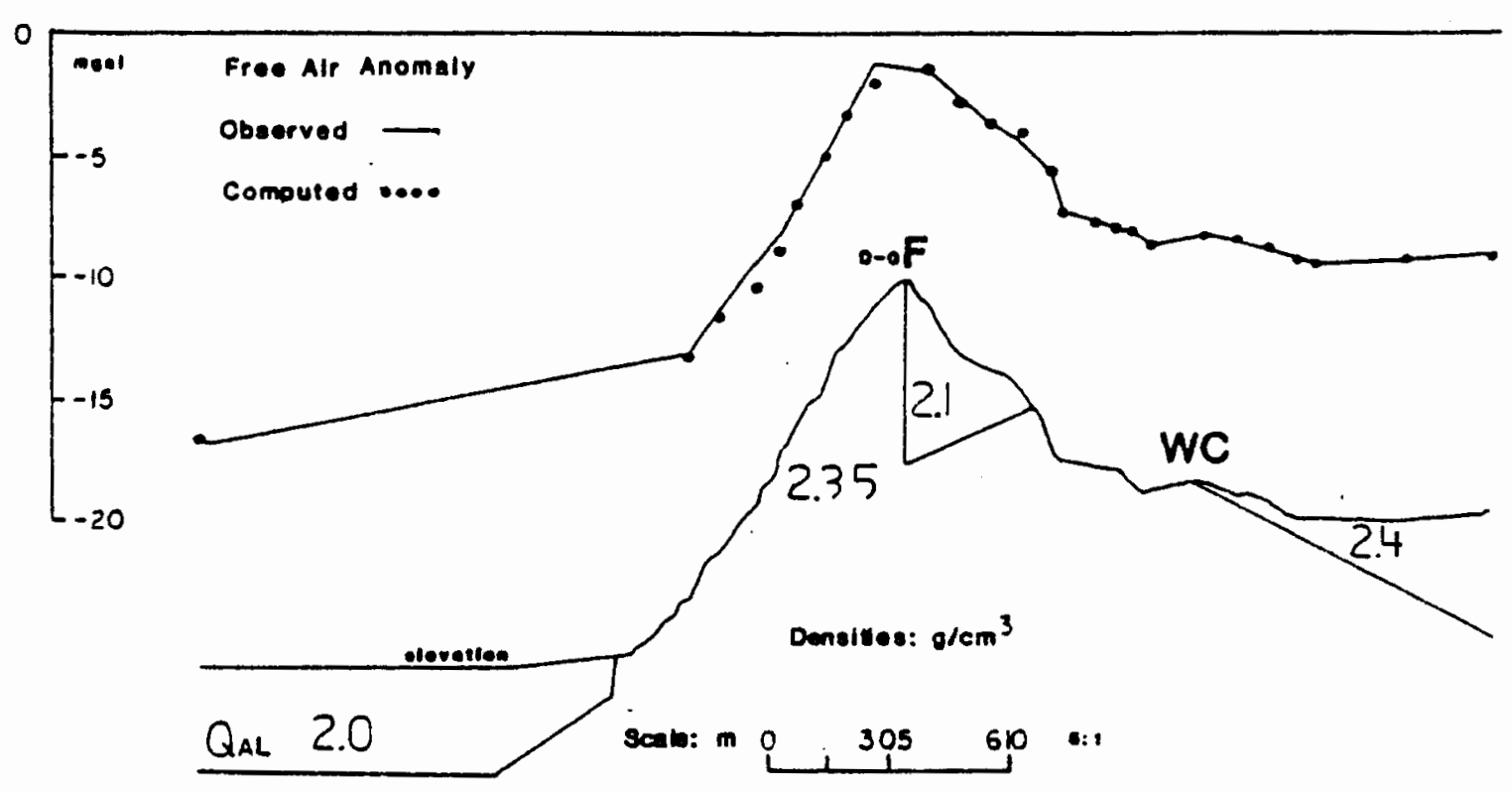

Figure 16. Gravity line $D$ showing the finished model 
north by a vertical contact, shown as fault $F$ on figure 16 . The boundary on the south is a gently dipping contact. The interpretation suggests a steeply dipping fault which trends roughly east-west occurs at the the northern boundary of this block. The southern boundary may be a fault which crosses the survey line at an oblique angle. This combination would meet at an angular intersection east of $D$ line. The geometry describes a section of a graben formed by two non parallel normal faults. The only other structure denoted by the model of $D$ line is the southern 720 meters is a block whose lower boundary dips to the south and extends beyond the area suveyed. The density of this block 3 was calculated to be $2.4 \mathrm{gm} / \mathrm{cm}$. This density value does not agree with the other values used in the model so the interpretation of this block is more difficult. Because of the dip of contact, the model suggests that it may be fault which is crossed at an oblique angle. The geometry of the contact suggests that the contact is a down to the south normal fault. The location and sense of movement are appropriate to the Willow Creek Fault, which would actually be down to the west. The density, however is higher than either the upper or lower layer. It may be an area of silicification combined with the upper layer. small hills around the nothern end of the contact show evidence of silicification. The density selected for silicification zones was 2.7 3 $\mathrm{gm} / \mathrm{cm}$, if a small area composed of silicified rocks were combined with a larger area composed of the upper layer the result would be to raise the density of the block in question. 


\section{E Line}

The E line is a north-south line located about 300 meters west of A Iine. It runs along the east flank of north Rhinehart Butte and crosses the peak of south Rhinehart Butte. Rhinehart Fault approaches E line in the southern part of Rhinehart Buttes and then gradually trends northwestward away from the survey line. E line crosses $\mathrm{A}, \mathrm{C}$, and $F$ lines in areas of the models of those lines which are described 3

by having an upper layer of the $2.1 \mathrm{gm} / \mathrm{cm}$ volcaniclastic unit.

In the north, E line is composed of recent sediments overlying the 3

lower layer of $2.35 \mathrm{gm} / \mathrm{cm}$. The model of $\mathrm{E}$ line, shown in figure 17 , consists of a low density bleck to the north. Immediately south is a small block of high density material. The rest of the line consists of six blocks of volcaniclastics, which are set into the lower layer. At the southern contact of the Malhuer River floodplain the model suggests a one point anomaly which requires a wedge of $2.6 \mathrm{gm} / \mathrm{cm}$ material. This could be either a narrow silicified zone, or possibly a bad or missed reading. The high density block is about 90 meters in width while extending to a depth of 50 meters.

To the south of this block is a portion of the lower layer which extends to the surface. This may be an erosional remnant which used to extend to the north, before being eroded by the Malhuer River, or there may a fault located in association with the high density silicification zone. If this latter case is true the location and offset may be masked by the silicification. The rest of the $E$ line consists of a layer of the upper unit volcaniclastics, which have been offset in a 


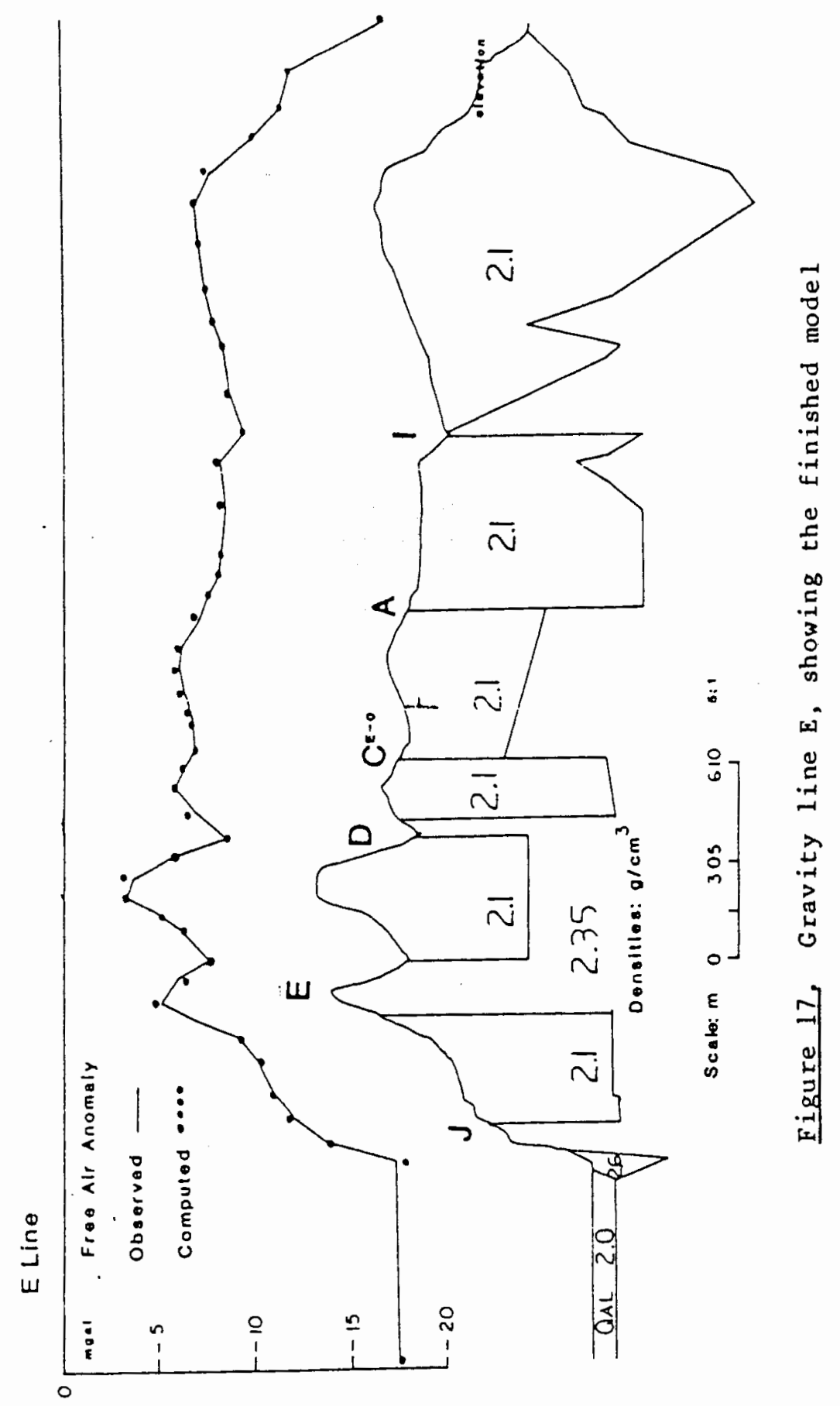


horst and graben configuration, with narrow zones of the lower unit extending between some of the blocks.

To the south of the northern block of the lower layer is a block of the low density upper layer which is bounded on the north by a vertical contact, noted as fault $\mathrm{J}$ on figure 17 . This block is about 360 meters wide and the northern contact suggests an offset of 70 meters. Field evidence suggests that in this location probably is a north dipping normal fault could be present, fault $E$ on the figure 17 . The rest of the block is a zone 180 meters wide of the lower layer. 3

The density of $2.35 \mathrm{gm} / \mathrm{cm}$ is perhaps not a window of the lower layer but a combined unit composed of a narrow high density silicification zone. At all locations modeled by the planes of the lower unit are conspicous zones marked by silicified country rocks. Such an interpretation would allow continuity of the upper layer across the length of the model and allow the offsets between blocks of the upper layer to be held down to a more reasonable distance. In the field at the these locations the fault is not visible because of the silicification and the offset is contained within one of the chick siltstone beds that characterize the formation. Wherever silicification has occurred withir one of these siltstone beds it is characterized by a very narrow width along a fault trace.

The southern boundary of the silicified zone is marked by a vertical contact with the upper layer. This block is bounded both north and south by the silicified zones and suggests that it is horst block which is raised in relation to the blocks on either side of it. This is interpreted as being bounded by a north dipping normal fault to 
the north and a southward dipping one to the south, labelled as faults $D$ and $E$ in figure 17. The northern offset would be about 52 meters while to the south the offset would be 53 meters. The block has a width of about 390 meters. The silicification zone to south of this block is about 30 meters wide and probably is a southward dipping normal fault, as shown in the interpretation, figure 18 .

To the south of this alteration zone is a narrow, 180 meters block of the upper unit which is downdropped to a graben position relative to the neighboring blocks. The bottom of the block dips gently to the north. The regional dip is to the northeast, so the northward component of the dip agrees with the field mapping. The offset of this block is modeled as 53 meters on the northern contact and 60 meters along the southern contact. The contact of the block is again vertical, but as with the other contacts a steeply dipping normal fault would seem appropriate. These blocks are all generally small and the offsets are also quite small so the amount of variance induced by steeply dipping contact is negligible when compared to a vertical plane over a small distance. The next block to the south is interpreted as a horst block. The bottom contact of this horst block dips to the south. The offset is again 60 meters in the north but increases to 170 meters on the southern contact. This southern contact is believed to be the same contact which bounds the western end of the small horst block in the middle of $C$ line, marked as A. The field evidence suggests a southeastward trending fault which runs between Rhinehart Fault and Wllow Creek Fault. This unnamed fault is a down to the west fault, so the sense of movement and location agree very well with the field 


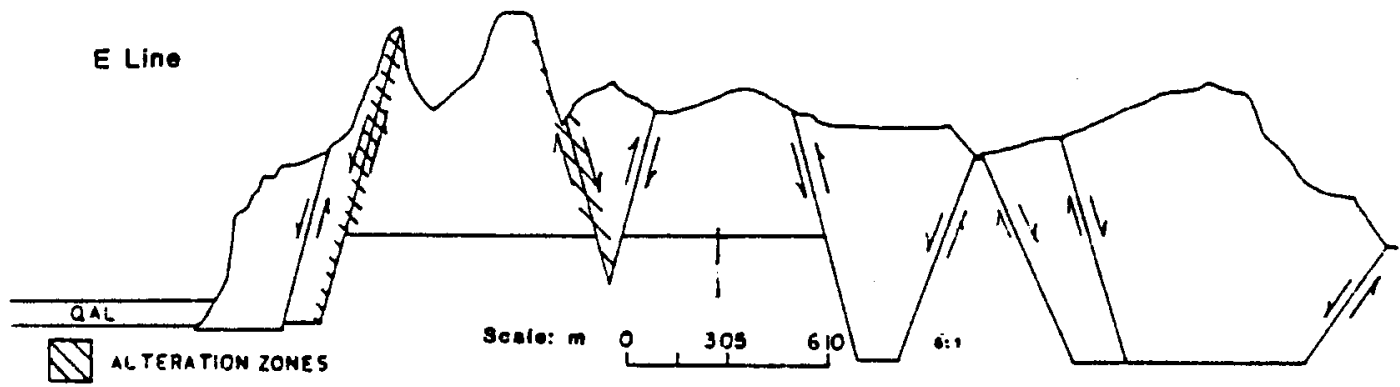

Figure 18. The interpretation of the model of E gravity line 
evidence. The southward dip of the block bottom is at odds with the local and regional dip. One-interpretation may be that at depth along the northern contact there may exist an silicified zone. This would have the effect of increasing the density within a small area and would be compensated for by raising the contact of the bottom of the upper layer.

The last block that composes north Rhinehart Butte is about 540 meters in length, and is a graben. The contact on the north and south are modeled as vertical. The block bottom is flat, with the exception of a one point anomaly. The anomalous value was considerably higher than the surrounding readings. The depth placement of that particular point was solved individually. The rest of E line southward contained several of these anomalous readings and the depth to each one had to be resolved individually. To the south is another silicified zore followed by a single block 1260 meters in length. The gravity model shows a very complex series of one point anomalies which contribute to make the bottom contact irregular and sawtoothed. The area consists of, at the surface, highly silicified country rock. The combination of normal faults and the large extent of silicification within this area have combined to present an irregular pattern of density contrasts. Field mapping and aerial photography study suggest that the valley between nortin and south Rhinehart Buttes is fault controlled. The Gravity model suggests that the valley is a complex intersection of possibly as many as four normal faults, this area is noted as I on figure 17. It would seem that south Rhinehart Butte has two en echelon normal faults, down to the south, which are closely spaced immediately 
south of the valley seperating the Buttes. The southern end of south Rhinehart Buttes also shows a variable geornetry along the climbing basal contact. This may be a single fault plane which displays areas of variable silicification at depth, see Plate $I$.

\section{F Line}

The $\mathrm{F}$ line is an east-west line that follows the section line between sections 21 and 28 , and is about 300 meters north of $A 1$ ine and crosses the northern end of Rhinehart Buttes. The model of the line, shown in figure 19, presents a similar type of picture as $\mathrm{E}$ line. The structure is that of the upper low density layer which has been subjected to en echelon westward dipping normal faulting. The portion of the line which crosses Rhinehart Buttes is made up of three blocks of volcaniclastics, and one block inserted into the lower layer east of Rhinehart Buttes. The westernmost block is about 780 meters in length and composes the entire western half of the Butte. Into this block are inserted two narrow bodies of high density which may represent silicification zones. The contacts along $F$ line are all westward dipping at $75^{\circ}$. This solution agrees with the field measurements of $74^{\circ}$ and $83^{\circ}$. The offsets are 95 meters and 90 meters along the faults. An offset in a prominent bed at this location can be seen in the field. The offset is less than ten meters, down to the east. The blocks east of the western block are 330 meters and 270 meters in length and occur in locations which agree with the model of $\mathrm{E}$ line. The eastern fault noted as fault $\mathrm{J}$. The block imnediately east of of the Buttes is a block of the lower layer, bounded on the west by a vertical contact. 


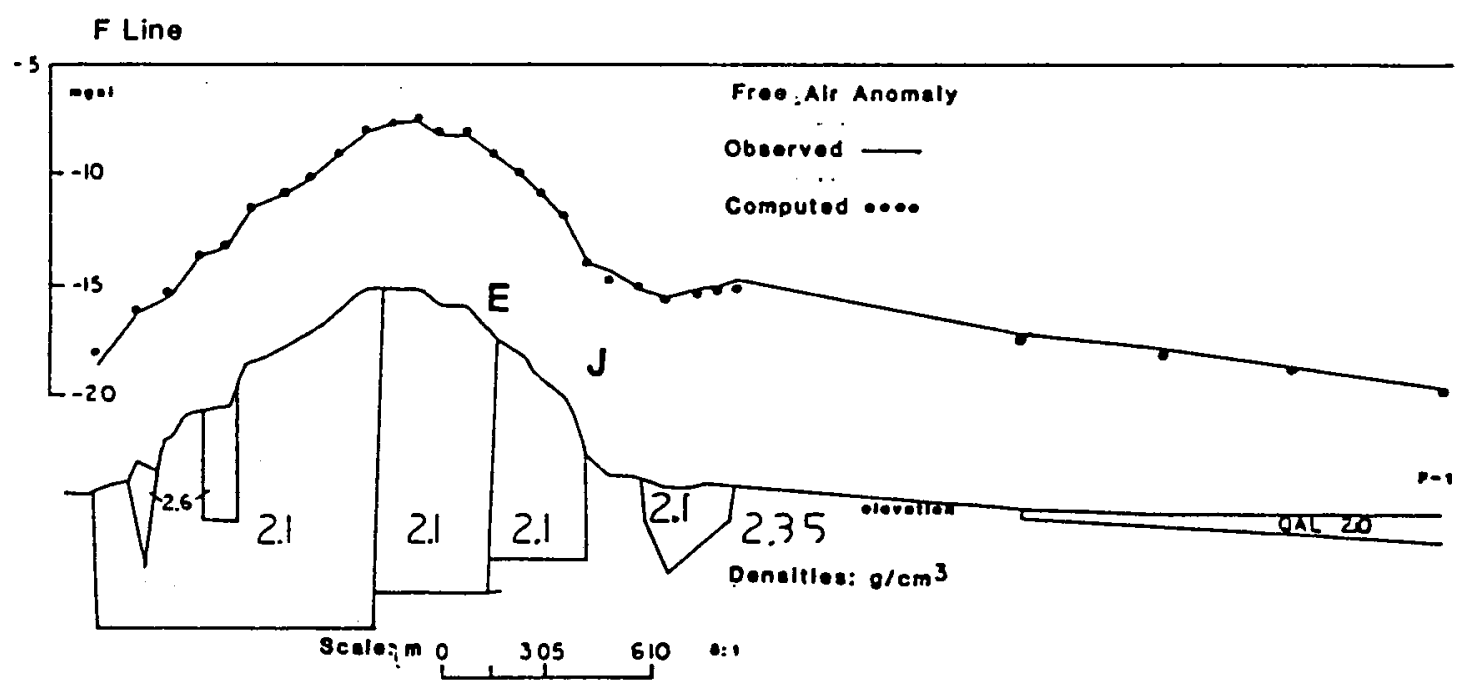

Figure 19. Gravity line $F$, showing the finished model 
This structure may be a small horst block. To the east of the horst block is a wedge shaped block of the upper layer, set into the lower layer. This structure may be a small graben bounded by normal faults trending at an angle to each other and intersecting near $F$ line. The two faults are noted as faults WC and $E$ on figure 17, and Plate I. The eastern, down to the west fault has a location which corresponds highly to expected location of the Willow Creek Fault.

The composite picture shows a structure possibly a down to east normal fault which lies just west of Rhinehart Buttes. Immediately to the east, near the crest of Rhinehart Buttes is the down to west Rhinehart Fault which would delineate the western portion of Rhinehart Buttes as a small graben. The area east of the fault consistantly appears as a downdropped block of the upper layer which has been deformed by a series of norteast ot east trending nornal faults. This section displays typical Basin and Range horst and graben structure, particularly in the north-south section. To the east from both the east-west and north-south directions the structure continues as horst and graben tÿpe structure. Vale Butte, after crossing the down to west Vale Butte Fault, seems to be one large block, with the exception of the northern shoulder. The northern end of Vale Butte shows a complex intersection of apparently normal faults. The field mapping of this area lends weight to this hypothesis, but does not supply enough to completely constrain the exact location of these structures. 


\section{Magnetic Modeling and Interpretation}

There are several unknowns which make the magnetic modeling a qualitative procedure, the susceptibility (k), which is dependant upon the magnetite content of the rock, and the remnant magnetization of the rock. Magnetic anomalies are caused by the differing magnetization of the rocks which is caused by differing amounts of amount of magnetite contained in the rocks and the remnant magnetization which is small and can be extremely variable. The anomaly in most cases is assumed to be generally caused wholly by induced magnetization (Telford et al, 1976). A proton procession magnetometer measures the total magnetic field of a station. The measurement is along the earti's field vector. F, the earth's field, is much larger than the local disturbance, $T$, because of this, the resultant vector is almost the same magnitude and direction as $\mathrm{F}$. In the Vale area the strength of the earth's magnetic field is about 55,000 gammas ( 0.55 gauss) and the inclination is 72 to 0

the north. The declination of 72 can approximate a total field vector that is vertical (Van Blaricom, 1980).

The size and shape of a magnetic anomaly are due primarily to the depth and magnetic susceptilbility of the source. In general, the wavelength of the anomaly is a function of the depth to the source. The longer the wavelength the deeper the source. The depth value is a maximum value for the depth to the source. The source may be, and usually is shallower than $1 / 2$ the wavelength.

The magnetic modeling contains three basic assumptions. The first is that the shape modeled will be a simple shape, such as a slab, or a 
sphere. Second is that there will be a uniform value for magnetization of the object being modeled. Thirdly, that there is a contrast between the magnetic susceptitibility values inside the object being modeled and the surrounding medium. Along with the assumptions made during the modelling there are several sources of error. Errors can be caused by magnetic noise, from power lines, radio towers, cars, and fencing. Magnetic storms can also cause error.

The reduced profiles of the six survey lines were first examined and compared to Boler's (1979) magnetic data, shown in figure 20. The purpose was to establish the location and magnitude of any regional magnetic anomalies. Because of the length of each of the survey 1 ines, four to six kilometers, the relationship between the location and position of the survey lines and the regional anomalies had to be considered. The study area, see figure 21 , is located on a large, southwestward rising, regional anomaly. The northeastern portion of the survey area recorded the lowest values, about 55,500 gammas. The values generally increased toward the southwest with a maximum value of 55,900 gammas occuring west of Rhinehart Buttes. Because of the regional anomaly the zero value for the modeling was established as 55,650 gammas. The contoured data revealed the relationship between the regional pattern and the local anomalies. The study area occupies the junction of two major trends, one which trends about $\mathrm{N} 60 \mathrm{~W}$ and the other about N60 E. The northwest trending line is an parallel to Lawerence's (1976) Vale Fault Zone, while the other may be related to an older Basin and Range trend. Lines $C$ and $G$ contained no clearly identifiable anomalies, other than the regional. Lines $B, E$, and $F$ 


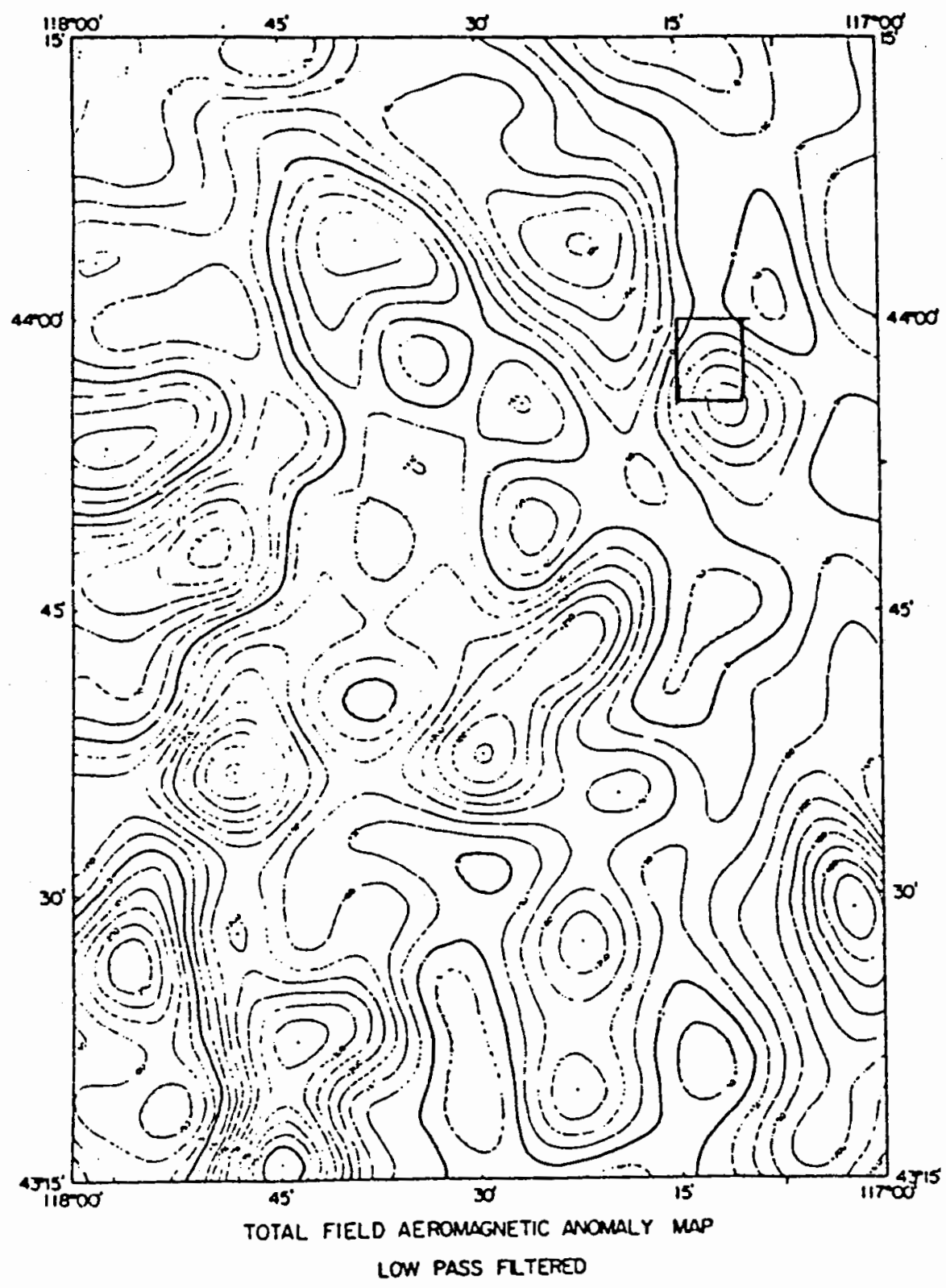

VALE-OWYHEE REGON MALMEUR COUNTY, OREGON

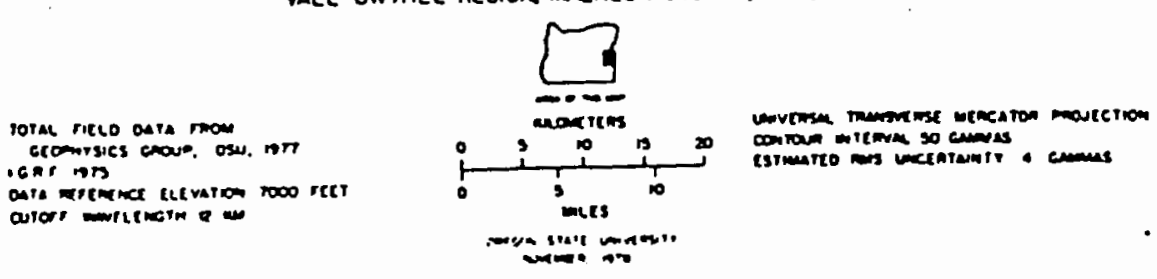

Low pass filtered aeromagnetic anomaly map of the Vale-Owyhee area.

Figure 20. Regional Magnetic Anomaly Map. The study area is outlined in black, from Boler (1979) 


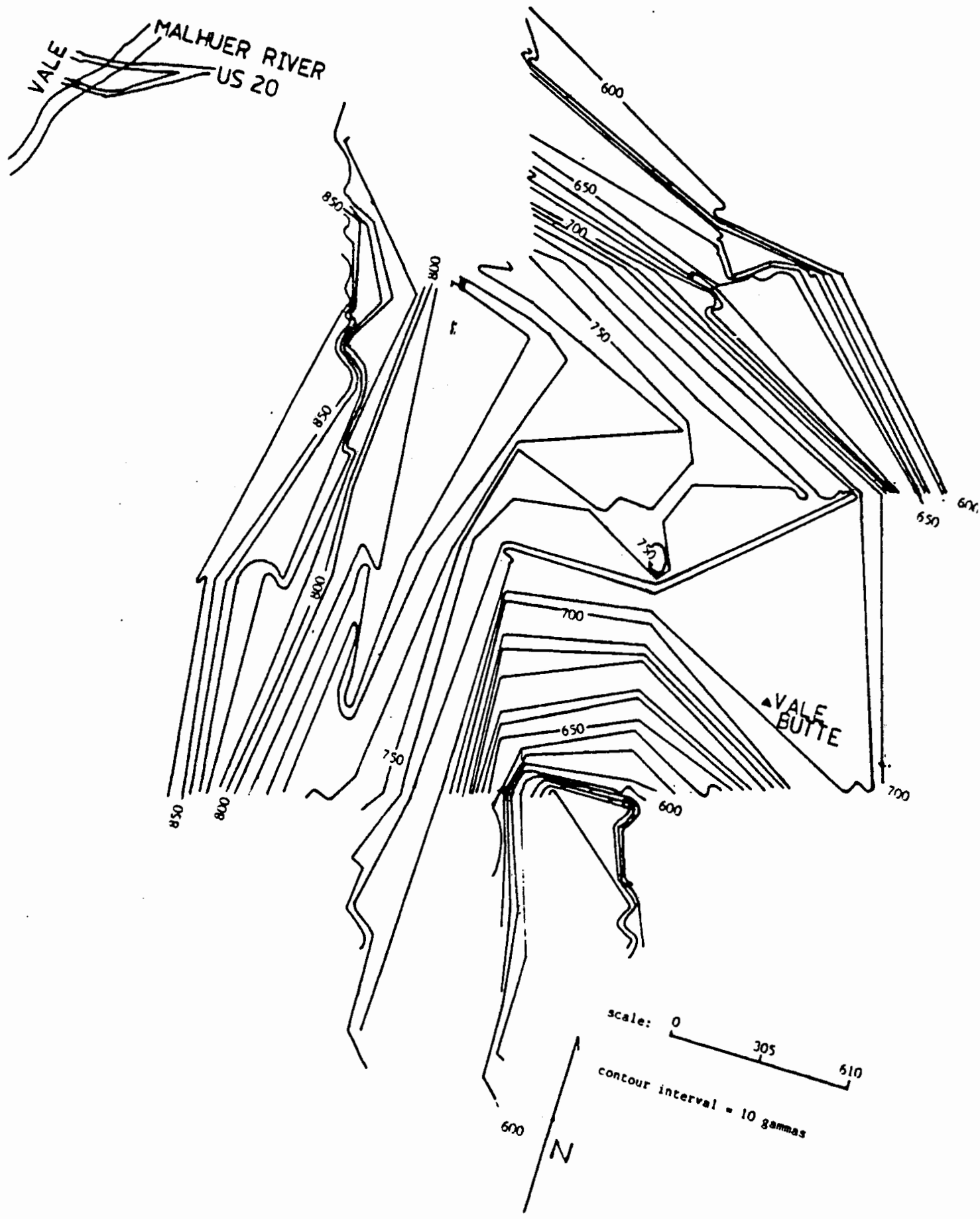

Figure 21. Contoured Magnetic Anomaly Map of the Vale Area. The town of Vale is located at the upper left. 
contained one recognizable anomaly of the appropriate wavelength each. Survey line D contained at least four local anomalies.

The initial step of the modeling process was to classify the type of the anomaly to be modeled. An anomaly could be result from a number of different sources. Example curves were prepared for the waveforms of anomalies generated by following features: alteration zones, a subsurface magnetic body, a thin magnetic sheet, and a faulted magnetic slab, these type curves are shown in figures 22 and 23 . The alteration caused magnetic anomaly was ruled out because the waveform shape was different than the observed anomalies, the location of the observed anomalies were not coincident with known locations for the silicified zones and magnetic susceptability of the observed silicified rocks was not in the magnitude range necessary to produce the anomaly. The other sources were each examined in this method, and evaluated for the possible use as a model. The only source which fulfilled the criteria for matching the observed anomalies was to model the faulted magnetic slab, where the magnetic susceptibility was in the range exemplified by basalt.

The modeling procedure was similar to that used in the gravity modeling. The simplest model was prepared first, and checked for fit, and if necessary models of increasing complexity were prepared as needed. The first stage was to examine each line to roughly determine the parameters needed for the model. The next step was to generate an initial simple model for comparison to the observed values. As needed the model would adjusted to obtain the best fit to the observed data. The initial model which was used to deternine the cause of the 


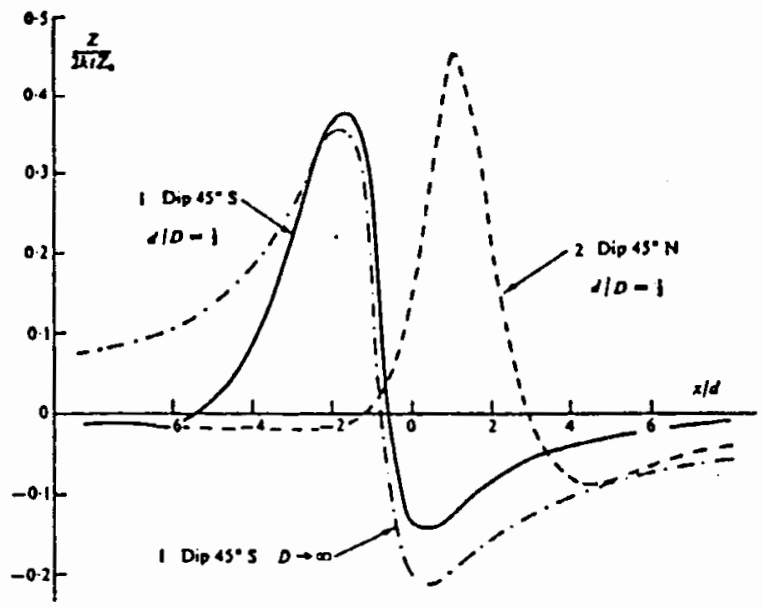

(c)

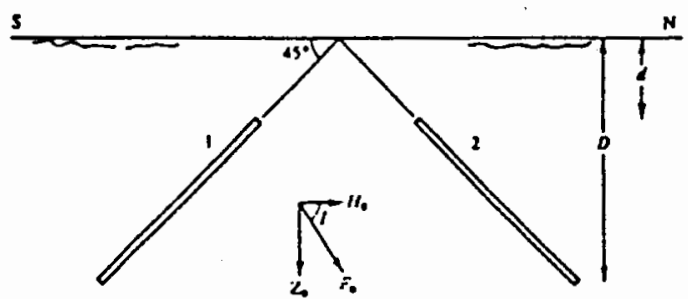

Fig. 3.26 Thin shoct, $Z$ curves, $l=60^{\circ}$. (o) Sheel striking NW-SE, dipping $45^{\circ}$ NE; (b) shoet itriking $N-S$, dipping $45^{\circ} \mathrm{E}, 90^{\circ}$ : (c) sheet striking E-W, dipping $45^{\circ} \mathrm{S}, 45^{\circ} \mathrm{N}$.

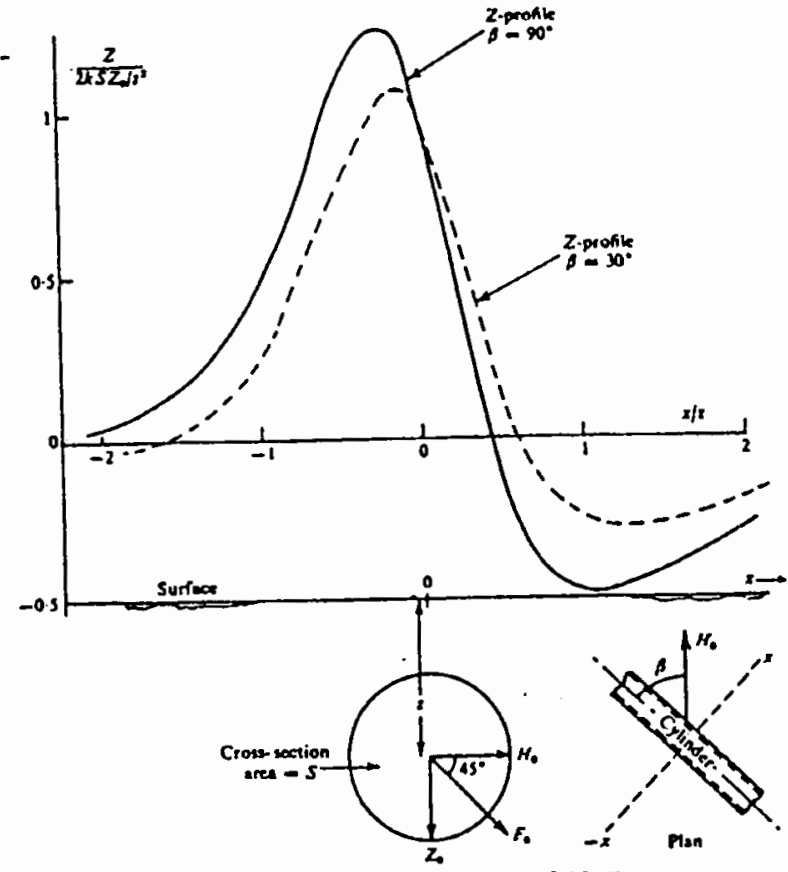

Fig. 3.23 Horizontal cylinder in earth's feld, $Z$ curves.

Figure 22. Typical magnetic anomaly wave form and sources, from Telford et al (1976) 


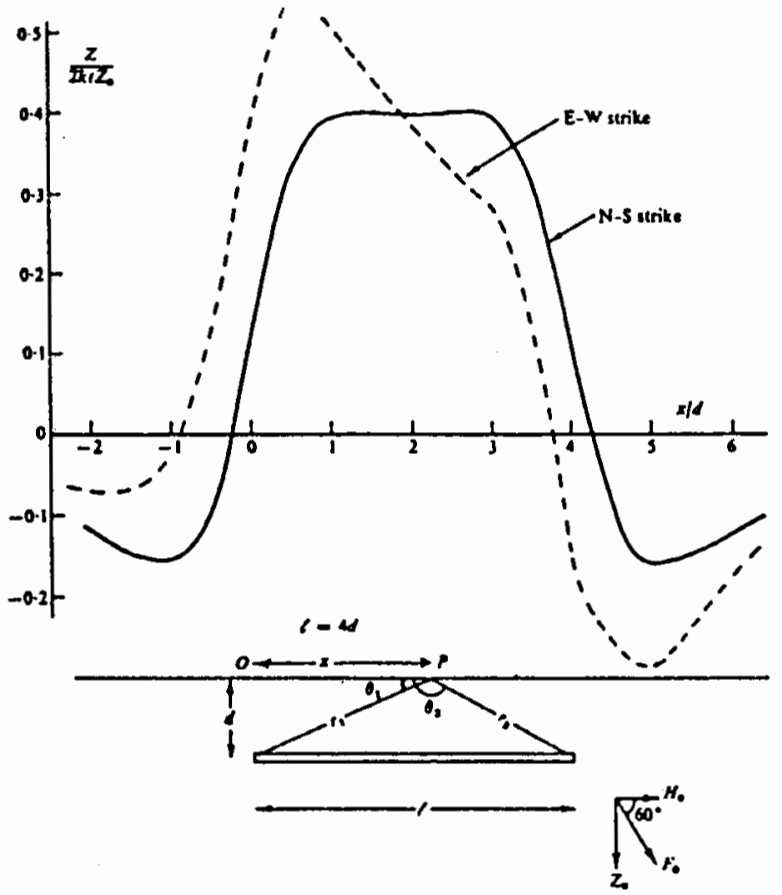

Fig. 3.27 Horizontul sheet striking N-S or E-W, $Z$ profile.

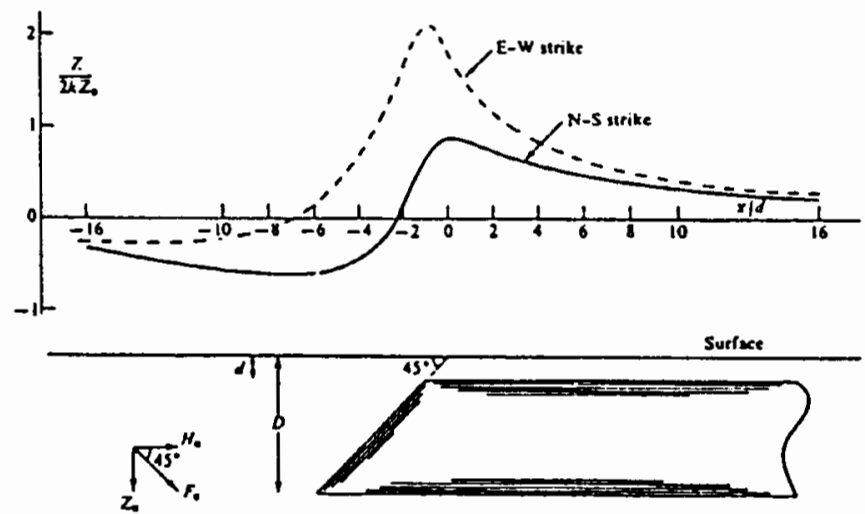

Fig. 3.30 Semi-infinite horizontal alab, odge striking N-S or E-W.

Figure 23. Typical magnetic anomaly waveform and sources, from Telford et al (1976) 
anomalies was a thick, horizontal buried slab of basalt, which was offset by vertical faults (Telford et al, 1976). The model was used as a basis for the rest of the modeling. Where necessary, the model was changed to utilize different burial depths, varying dips on the fault planes and faulted dipping beds. Various combinations of these models would be necessary to compare to the observed. The fault plane solutions were worked out for fault dips of $90,75,60$, and $45^{\circ}$. Additionally, the magnetic susceptability of the units modeled wre estimated from Telford et al (1976).

\section{B $\underline{\text { Line }}$}

The initial model was prepared for B line, shown in figure 24, which trends $\mathrm{N} 70 \mathrm{E}$ and includes the magnetic base station. B line crosses gravity lines $A$ and $B$ at the base station. The magnetic profile of $B$ line displays a distinct local anomaly with a wavelength of about 1150 meters, superimposed upon the regional trend. The anomaly is centered over the northwest shoulder of Vale Butte. The depth to the feature causing the anomaly is vital in this location. Brown (1982) states that basalt of the Grassy Mountain type is found at a depth of about 200 meters in the Malhuer River floodplain, north of Rhinehart Buttes. The best fit solution indicates that the depth is in the 400 meter range. However, because of the reasons referred to in the opening paragraphs of this section, the 400 meter depth is considered a maximum value. The model predicts that the anomaly is generated by a fault with an offset of about 100 meters. Again the value of the offset should be considered a maximum value with the actual value 

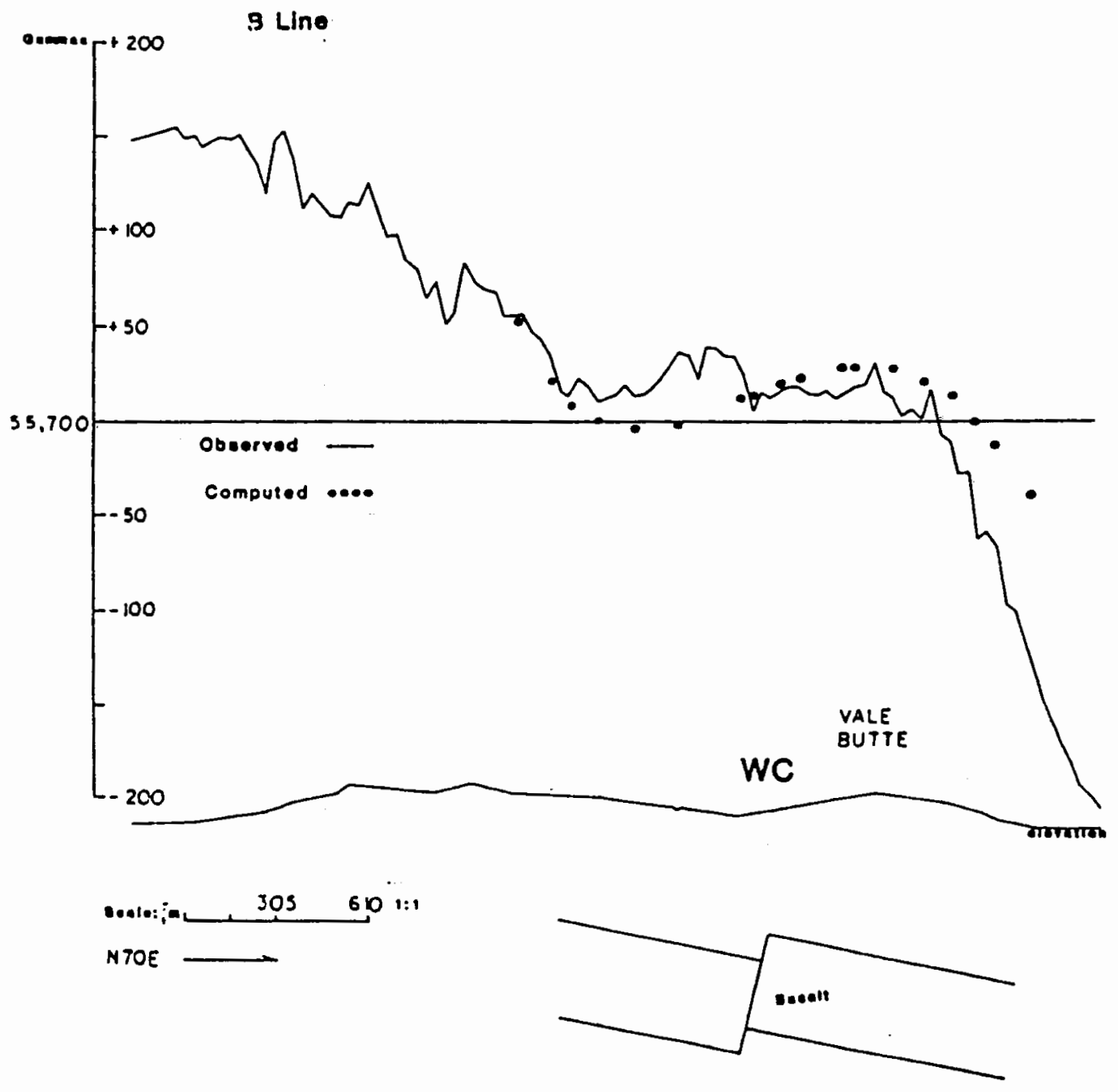

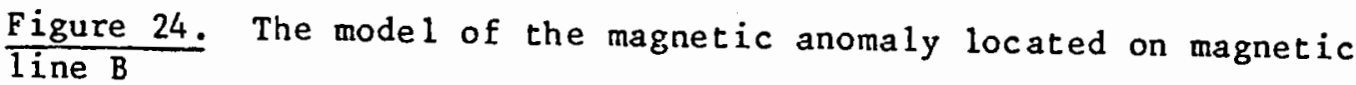


probably less. These maximum depth values fit within the constraints supplied by the well log data (Brown, 1982).

The best fit solution called for a thick eastward dipping slab of basalt which has been offset 100 meters by a normal fault which dips westward at an angle of $75^{\circ}$. The fact that the model predicts a slab that dips to the east at 15 and field mapping gives the dip of the beds in that location as ranging from 8 to $18^{\circ}$ to the northeast represents a reasonable correlation.

\section{Line}

The D line trends parallel to $B$ line at $N 70^{\circ} \mathrm{E}$. The line is the most southerly of the survey lines, and crosses $C$ gravity line at the crest of Vale Butte. The profile of the magnetic values for $D$ line show six distinct local anomalies. Three of the anomalies occur east of Vale Butte in an area where coverage by verifying gravity and magnetic survey lines is limited. Although the anomalies were modeled, shown in figure 25, verifying data from other sources is lacking. The portion of ti,e line running between Vale and Rhinehart Buttes is fully supported by both other magnetic and gravity lines.

The modeling procedures outlined earlier were used to estimate the depth and sources of the anomalies. The sources of the anomalies are normal faults. All have suggested offset of about 100 meters, and the variations in the computed depth to the structure generally concurs with the local estimated dip of the units.

The easternmost fault is a normal fault, which dips to the west at 0

75. A number of faults occur in the area, however identification of 
that particular structure has not been accomplished. Note on Plate I there are several faults in the immediate vicinity which can fit the model. The depth to source is 300 meters and is down to the west. This fault may be either the east-west trending fault or the northeast trending fault, which are both located in close proximity to this portion of the D line. The same applies to the next fault to the west. As this particular area is crossed by several faults of differing trends, each fault has possiblities of being the fault that is the source of the anomaly. The depth to source is 240 meters, and the fault is vertical. The fault located on the eastern flank of Vale Butte does not agree with data from the gravity model of $C$ line which occupies the same general area. A gravity line, to the north of the location of the magnetic anomaly suggests an eastward dipping normal fault, see figure 10, fault $G$. Because of the nature of the structure of the area these two structures may in fact both be present and be two distinct and unrelated features.

The third fault to be modelled on D line occurs near the western base of Vale Butte. The model depicts a down to the east normal fault. The model predicts the presence of a vertical normal fault at a depth of about 480 meters. This particular fault has not been identified in either the gravity modeling portion, or by field mapping. The next fault to the west, noted as WC is the Willow Creek Fault. The magnetic model has a source depth of 500 meters. The depth estimate is believed to be too deep, but this estimste is a maximum value, and the physical presence of the structure is believed to be somewhat shallower. The location of this fault, agrees well with that predicted by the gravity 
models for a westward dipping normal fault. The amount of offset agrees with that predicted by the model of A gravity line for the same feature. The offset required by the model of $\mathrm{C}$ gravity line is somewhat less. Field mapping has added evidence of offset in that area.

The final and westernmost anomaly modeled on D line occurs on the eastern flank of south Rhinehart Buttes. The model predicts an eastward dipping normal fault with an offset of about 100 meters. This fault, together with the Willow Creek Fault are the boundaries to a small graben, occuping the valley between the Buttes. This graben, is present only in the southern portion of the survey area and is terminated by cross faulting near $C$ gravity line. Again this structure agrees with both the gravity modeling and field evidence as to location and sense of movement. Because of the consistant evaluation of the offset at 100 meters, and the approximation style of the magnetic modeling the value of the offset is suggested as maximum value. The most important aspect of the magnetic modeling is the fact that those faults which extend down to the Grassy Mountain Basalt generally agree in both location and sense of movement with those faults that have been modeled as part of the gravity study and field mapping.

\section{$\underline{\text { and }} \underline{\mathrm{F}}$ Lines}

Both $\mathrm{E}$ and $\mathrm{F}$ lines trend $\mathrm{N} 20 \mathrm{~W}$, and are shown in figures 26 and 27. E line is the easternmost of the magnetic lines and crosses through the magnetic and gravity base station. F Iine is parallel to E line and is located about 500 meters west of the E Iine. The solutions 


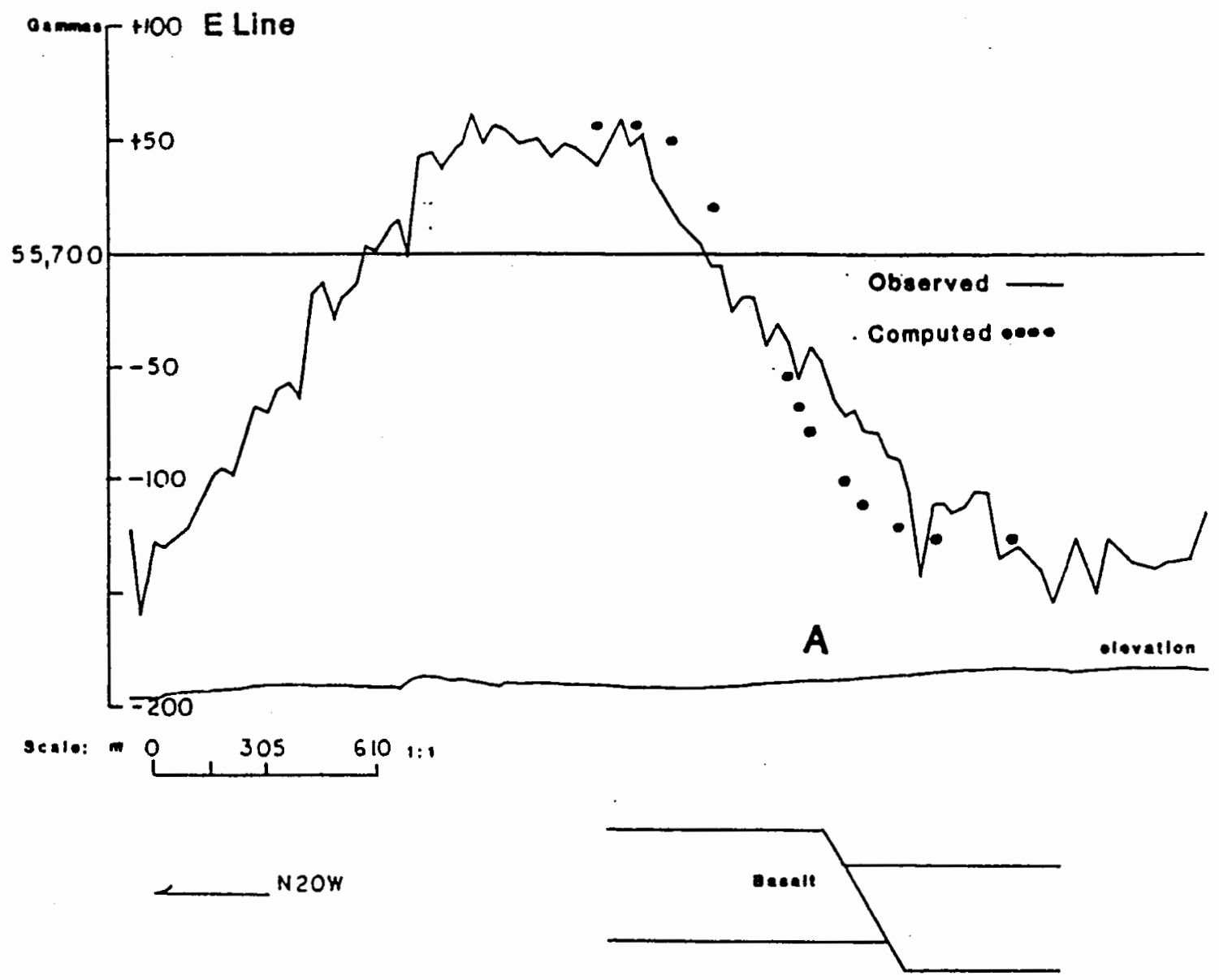

Figure 26. The model of the magnetic anomaly located on magnetic Iine $\mathrm{E}$ 

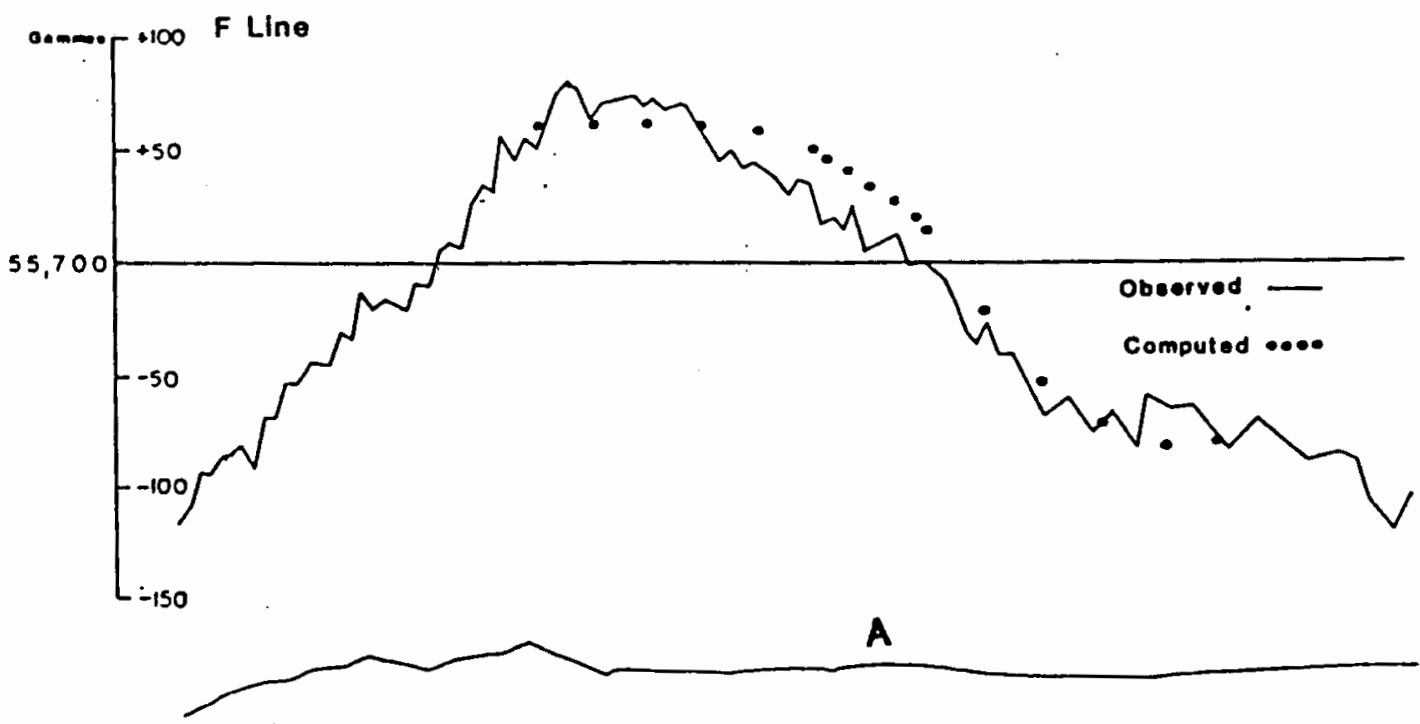

Scalo: : $\underbrace{0} 305 \quad 6101: 1$
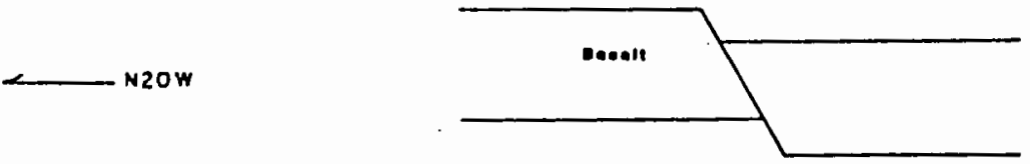

Eigure 27. The model of the magnetic anomaly located on magnetic line $\mathrm{F}$ 
and structures for the models for both are very similar and are probably caused by the same structure. The locations and apparent dip suggest that the structure, a southward dipping normal fault are the westernmost anomaly causing fault which is described in D line. The apparent dip, which the model suggests as $60^{\circ}$ is probably a steeply dipping fault plane which is crossed at an oblique angle by both survey lines. The model has a source depth of 400 meters and an offset of 100 meters. The source is the fault labelled $A$ in the figures and Plate I. 
CHAPTER V

\section{CONCLUSION}

Located beyond the western margin of the study area is a large, normal fault which dips steeply to the west. This fault is unnamed and has been identified only through the use of geophysical techniques. There is no fault trace visible at the surface. This unnamed fault has been located and verified by both Lillie (1977), and although it lies outside the study area is seen in this study. The estimated displacement along this fault which may be part of, or possibly, an extension of the Bully Creek Fault is 850 meters. The fault is a boundary between a regional horst and graben. The graben lies to the west of the study area, which is centered on the horst. The blocks have been informally named the Vale horst and graben. The Vale Horst underlies the study area.

The western jortion of the study area consists of a set of smaller horst and graben structures, which are on the western edge of the Vale horst block. These smaller structures are also located by geophysical studies under the alluvial plain west of Rhinehart Buttes. There are no visible fault traces at the surface. The size, horizontal separation and estimated offsets along these structures is smaller than the Vale horst and graben and these smaller atructures have been classified in this study as belonging to the Vale horst structure. On the western edge of the study area is a small horst, see Plate I. The 
horst block is about 500 meters wide. Geophysical modeling suggests that displacement is about 300 meters upward, relative to the eastward adjacent portion of the Vale horst. The orientation of bounding faults of this block were not determined because only one geophysical line transversed the structure; however Lillie (1977) suggested that the orientation is to the northwest, approximately parallel to other structures within the area.

The eastern boundary of the sinall horst is an eastward dipping normal fault. This eastern boundary is located about 1000 meters to the west of Lytle Boulevard and beneath the meanders of the Malhuer River in sec 32 shown on Plate $I$. This structure was located in the modeling of the $C$ gravity line.

Located at the western base of Rhinehart Buttes is an eastward dipping normal fault. The gravity model suggests that the fault is down to the east. The displacement of this fault is about 90 meters. This fault, labeled $H$ on Plate $I$ is covered by colluvium and is not visible on the surface.

The crest of Rhinehart Buttes is marked by a fault which dips 83 to the west and the west side is downthrown. The western portion of Rhinehart Buttes is a graben. The model of the $\mathrm{C}$ gravity line (see figure 10) suggests a maximum throw of about 50 meters. The valley to the east of Rhinehart Buttes contains several faults. The principal fault trends $\mathrm{N} 60 \mathrm{~W}$ and is located at the western base of Vale Butte. The west face of Vale Butte is an eroded fault scarp. Willow Creek Fault is a west dipping nornal fault. The gravity models of $B$ and $C$ lines, the magnetic model of the D line and possible stratigraphic 
correlations suggest a maximum displacement of about 100 meters along the fault. This is the fault denoted as WC on Plate I. gravity and magnetic modeling do not detect strike slip movement. Strike slip movement is detectable only if the movement resulted in a density contrast, for gravity, or resulted in the offset in a vertical sense of the basalts at depth, for magnetics. There is a clear change of structural orientation across the Willow Creek fault. To the west the o small cross faults strike about $\mathrm{N} 30 \mathrm{~W}$ while those to the east have a consistent strike of about N30 E. The north-south offset in the topography between Vale and Rhinehart Buttes, also suggests right lateral motion. Several faults, traceable over a considerable distance and are in the appropriate location, are considered as the southern extension. On all of these structures the fault trace is lost both to north beneath the alluvium of the Malhuer River and to the south, beneath the Pliocene to Pleistocene sedimentary rocks.

The other major structure within the valley between Rhinehart and Vale Buttes is another normal fault which fault trends about N40W and dips to the wast and is labeled $A$ on Plate $I$ and figures 14 and 17 . Fault $A$ has been detected in the models of gravity lines $C$ and $E$ and magnetic lines $E$ and $F$, as well as by field mapping. This fault runs from Rhinehart Buttes to the east side of the valley where it intersects the Vale Butte Fault. Fault A was part of the conduit system for the fossil hot springs and shows silicification along part of the length. That part of the fault which displays silicification is the linear ridge in the $\mathrm{SW} / 4$ of $\sec 28$ (see Plate $\mathrm{I}$ ). The ridge is an example of inverted topography where the silicified rocks are more 
resistant than the country rock. Displacement along fault $A$ is a maximum of about 30 meters and the Rhinehart fault is displaced to the west along the trend of fault $A$ indicating that it was active after the formation of Rhinehart fault. Fault A may have been active as recent as the Pleistocene because at one location the sediments of Captain Keeney Pass are truncated by this structure. The Pleistocene rocks may have been deposited over the fault or up against the fault scarp and erosion exhumed the trucation (see plate I).

In the horst block, bounded by the Rhinehart Fault on the west and the Willow Creek Fault on the east, are a number of north to west trending normal faults. These faults, when viewed on a north-south section, shown in Plate III, show a series of small horst and graben structures which extend the length of Rhinehart Buttes. Some of these fault seem to reach their maximum offset at or near the Rhinehart Fault and the offset diminishes to the east. Some of these small hinge faults appear to end before reaching the Willow Creek Fault while others apparently intersect the fault (see Plate I). These small faults must have occurred after the activation of Rhinehart Fault as it is offset by these smaller structures. These small faults show silicification in places, see Plate II, so may have been active during the existence of the hot spring system which caused the silicification along Rhinehart Fault.

The northwest trending fault east of Vale Butte is another of the regional structures. Lillie (1977) suggests a normal fault, or possibly a strike slip fault with oblique movement, traverses the area east of Vale Butte. While Lillie (1977) suggests a down to the east 
movement the supportive evidence in this report is ambigous. Field evidence in the northern part of the section indicates a down to the east movement, while in the southern portion the sense of motion is down to the west. The gravity models of the $A$ and $C$ lines based on Lillie's (1977) model do concur, and field evidence, apparent drag folding and apparent offset of conglomerate beds on the northeast shoulder of Vale Butte agree, see map, Plate I. Brown (1982) suggests a down to the west movement. Supporting Brown's (1982) contention are: the magnetic modeling (see figure 25), drag folding in the sandstones that form the dip slope east of the southern part of Vale Butte and the apparent offset of the beds of Captain Keeney Pass in the southern portion of the study area, see geologic map, Plate I, support Brown's (1982) contention. The fault is probably a scissors type fault which is down to the east in the north and down to the west in the south, with the hinge located just to the south of Vale Butte.

Along the northern side of both Vale and Rhinehart Buttes the pattern seeus to be one of en echelon normal faulting. The dip of the fault planes is generally northward, with the north side downthrown. The northern section of Rhinehart Buttes may be composed of either a series of slump blocks or a series of small en echelon fault blocks. The gravity studies in this study show a distinct series of blocks with en echelon progressive down to the north along the northern side of the Butte. Brown (1982) has mapped this area as landslide debris. The model predicts a series of block of the same density as the country rock. Field mapping also shows conflicting evidence. In some areas the bedding and fabric of the country rock is shattered and distorted 
while in another outcrop the same features appear normal. This could be the result of post deformational slumping along the fault planes or could be the result of blasting during highway construction.

The structural history seems to indicate that the Rhinehart Fault was active earliest. This was probably during the early pliocene at the latest. These systems can probably tied to Basin and Range deformation. Sometime later a second episode of deformation resulted in the stuctures which have a more western component in their trend. These displaced the earlier structures, notably the Rhinehart Fault. These faults indicate extension, via horst and graben faulting, to the northwest-southeast. These faults may be associated with right lateral movement of the Vale Fault Zone. The direction of extension is in the appropriate direction and it is possible that much of the strike slip component of the movement took place as both right lateral and ball bearing type extension of the entire Vale Fault Zone. Also possible is that the right lateral movement of the Vale Zone and Willow Creek Fault was a seperate episode of deformation.

The results of this study support the conclusions of previous authors, notably Lillie (1977) and Bowen and Blackwell (1975). The study area is composed of regional horst and graben features, of which the Vale Horst occupies most of the study area. The Vale Horst is composed of a large number of small, fault bounded blocks as suggested by the gravity and magnetic modeling. The majority of the structures ouggested by the geophysical otudies have been confirmed by the presence of supporting field evidence such as drag folding, offset of units or repetition of units. The overall sense of movement is 
probably oblique. However, the evidence supporting the contention of a right lateral component of the movement is marginal, limited to topographic expression.

The results of the gravity survey suggest that the study area is centered on a large horst. The boundaries of the horst lie about two kilometers west of Rhinehart Buttes and to the east of Vale Butte. The 3

horst is capped by a low density, $2.1 \mathrm{gm} / \mathrm{cm}$, volcaniclastic unit which has been offset a series of small, short throw, local faults. These small faults are normal faults. The base of the upper unit shows distinct offset, and the density contrast is generated by the faulting of the upper unit against the more dense lower unit. At areas identified by field as silicified zones the gravity modeling suggests 3 dense, $2.7 \mathrm{gm} / \mathrm{cm}$, bodies which parallel the known faults at those locations. Field evidence shows the silicified zones are located along the faults, which acted as plumbing for a fossil geothermal system. Rhinehart Buttes are erosionally resistant silicified remnants of a fossil hot spring system (Bowen and Blackwel1, 1975). Rhinehart fault apparently was a conduit for the fossil hot springs. The most intense silicification and secondary mineralization occurs along the fault trace. The degree and distribution of the silicification seems to be controled by the location of the fault plane and the permeability of country rock intersected by the fault (Benson, 1981 pers. comm.). In units of low permeability, the silicified zone is narrow and centered on the fault plane while in units of higher relative permeability the zone is much wider. Rhinehart fault is offset by other, later faults. Those areas which display the highest degree of silicification are 
localized in areas where Rhinehart fault interescts other faults. Gravity modeling predicts that the silicified zones are generally dense dike like bodies in a matrix of lighter, $2.1 \mathrm{gm} / \mathrm{cm}^{3}$, volcaniclastic material of the upper layer.

The magnetic models correlated well with the gravity models. The magnetic models predicted that the Grassy Mountain Basalt, which underlies the upper layer examined in the gravity modeling, is offset at several corresponding locations by normal faults. The main, larger faults extend downward into and possibly through the Grassy Mountain formation. The locations of the larger faults are coincident with those predicted by the gravity modeling.

The heat flow measurements, Bowen and Blackwel1, (1975), support the hypothesis of greater than average heat flow. The world wide average for continental areas is 1.4 Heat Flow Units (HFU), measured in 2 microcalories per $\mathrm{cm}$ per second, while in the Vale KGRA heat flow measurements range from a low of 2.3 to a high of $6.4 \mathrm{HFU}$, (Bowen and Blackwe11, 1975). This condition requires that a fluid medium must be available to circulate and transfer the heat (Black, 1984, pers. comm). Conductive heat transfer is not effective enough to maintain the high rate found in the Vale KGRA. The hot springs located both to the north and west of Rhinehart Buttes are evidence that fluid medium is present. However, the amount of geothermal fluid acting as a heat source at the hot springs is limited. The Grassy Mountain Basalts underly the volcaniclastic rocks that are exposed on the surface. The fractured nature of basalt flows could make excellent reservoir rocks for the geothermal water. The drilling operations so far have not encountered 
any appreciable fluid flow at depth. None of these wells however were drilled near the intersection of the faults believed to be controlling the upward fluid migration.

The structural controls of the the hot springs at Vale were examined. The area of present primary interest is located at the north end of Rhinehart Buttes. The linear, directional pattern of temperature increase within the acquifer that feeds the hot springs combined with the structural configuration suggest that the controlling structure is probably associated with those structures at the northern end of Rhinehart Buttes. Of particular interest is the Rhinehart Fault. The orientation of the Rhinehart Fault trace coincides with the location of the group of hot springs that occur along the Malhue) River. The drilling operations conducted in April, 1982 were unsuccessful at encountering the uprising thermal waters. However, Rhinehart Fault was intercepted at a depth of about 360 meters. The drilling was suspended upon loss of circulation due the large void spaces encountered at Rhinehart Fault. The void spaces are an indication that the altered, brittle, and highly fractured rocks along the fault have the porosity necessary to allow the upward fluid migration. The directional temperature increases noted within the shallow warm water acquifer show a trend of $\mathrm{S} 29^{\circ} \mathrm{E}$. The north end of Rhinehart Buttes appears to be structurally composed of a series of en echelon down to the north normal faults. The east-west trending ridge which composes the north end of Rhinehart Buttes is cored by a northeast trending, northward dipping fault. This ridge shows evidence of silicification and brecciation at sever? places along its length. 
The location of this fault is $\mathrm{S} 15 \mathrm{E}$ in relation to the hot springs. The direction of temperature increase within the shallow acquifer trends toward a part of this fault (Brown, 1982). This fault is probably the crucial factor in controlling the injection of thermal waters into the shallow acquifer. Rhinehart fault, which probably was at one time, the prinary structure appears, as a result of the 1982 drilling to be secondary, but may be a primary control at depth (Gannett, 1986, pers. comm.). 


\section{BIBLIOGRAPHY}

Applegate, D.E. and L.L. Donaldson. 1979. Seismic section in Ontario Oregon: Geothermal Resources Council Bulletin, v. 3 , p. $15-17$.

Baldwin, E.M., 1964, Geology of Oregon: Eugene, Oregon, University of Oregon Cooperative Bookstore, $165 \mathrm{p}$.

Baldwin, H.L., and Hill, D.P., 1960, Gravity survey in part of the Snake River Plain, Idaho -- A preliminary report: U.S. Geological Survey, open file report (200) R290, No. 511.

Berg, J.W. and Thiruvathukal, J.V., 1965, Gravity base station network, Oregon: Journal of Geophysical Research, v. 70, p. 3325 3330 .

----, 1967a, Free air gravity anomaly map of Oregon: Oregon Department of Geology and Mineral Industries, GMS 4a, scale $1: 500,000$.

---, 1967b, Complete Bouguer gravity anomaly map of Oregon, Department of Geology and Mineral Industries, GMS 4b, Scale $1: 500,000$.

Boler, F.M., 1979, Aeromagnetic measurements, magnetic source depths, and Curie point isotherm in the Vale - Owyhee Oregon geothermal area: unpublished thesis, M.S., Oregon State University, Corvallis, Oregon.

Bowen, R.G., 1972, Geothermal gradient studies in Oregon: The Ore Bin, v. 34 , no. 4 , p. $68-71$.

Bowen, R.G., and Blackwell, D.D., 1973, Progress report on geothermal measurements in Oregon: The Ore Bin, v. 35, no. 1, p. $6-7$.

-- 1975, The Cow Hollow geothermal anomaly, Malhuer County, Oregon: The Ore Bin, v. 37, no. 7, p. $109-121$.

Bowen, R.G., and Peterson, N.V., 1970, Thermal springs and wells in Oregon: Oregon Department of Geology and Mineral Industry, miscellaneous paper number 14 .

Brown, D.E., 1982, Map showing geology and geothermal resources of the Vale East $71 / 2^{\prime}$ Quadrangle, Oregon: Oregon Department of Geology and Mineral Industries, GMS 21, scale 1: 24,000.

Bryan, K., 1929, Geology of reservoir and dam sites with a report on the Owyhee Irregation Project, Oregon: U.S. Geological Survey, water supply paper 597-A:89 p. 
Cooper, J.A. 1980. Oregon geothermal overview study. Oregon Graduate Center, Beaverton Oregon.

Cope, E.D., 1883, On the fishes of the Recent and Pliocene lakes of the western part of the Great Basin, and of the Idaho Pliocene Lake: Acadamey of the Natural Sciences of Phiadelphia Proceedings:134-166.

Corcoran, R.E., Doak, R.A., Porter, P.W., Pritchett,F.I., and Privrasky, N.C., 1962, Geology of the Mitchell Butte Quadrangle, Oregon: GMS 2, scale 1:125,000.

Couch, R.S., French, W.S., Gemperle,M., and Johnson, A.G., 1975, Geophysical measurements in the Vale, Oregon Geothermal resource area: The Ore Bin, v. 37 , no. 8, p. $125-129$.

Couch, R. and Baker, B., 1977, Geophysical investigations of the Vale-Owyhee Geothermal Region, Malhuer County, Oregon: Technical Report No. 2, U.S. Geological Survey, Geothermal Research Program.

Evernden, J.F., and James, G.T., 1964, Potassium-argon dates and the Tertiary floras of North America: American Journal of Science, v. 262 , p. $945-974$.

Goguel, J., 1954, A universal table for the prediction of the lunar-solar correction in gravimetry: Geophysical Prospecting, v. 2, p.1 - 32

Hammer, S., 1939, Terrain corrections for gravimeter stations: Geophysics, v. 4, no. 3, p.184 - 194.

Hull, D., 1975, Geothermal studies in the Vale Area, Malhuer County, Oregon: The Ore Bin, v. 37, no. 6, p. $104-106$.

Johnson, A.M., 1961, Stratigraphy and lithology of the Deer Butte Formation, Malhuer County, Oregon: unpublished thesis, M.S., University of Oregon, Eugene Oregon, $144 \mathrm{p}$.

Jones, T.D., 1977, Analysis of a gravity traverse south of Portland, Oregon: unpublished thesis, B.S., Portland State University, Portland, Oregon.

Kirkham, V.R.D., 193la, Pevision of the Payette and Idaho Formations: Journal of Geology, v. 39, p. $193-239$. 
Kittleman, L.R., Green, A.R., Hagood, A.R., Johnson, A.M., McMurray, J.M., Russel1, R.G., and Weeden, D.A., 1965, Cenozoic stratigraphy of the Owyhee region, Malhuer County, Oregon: Eugene, Oregon, University of Oregon Museum of Natural History Bulletin 1, $45 \mathrm{p}$.

Kittleman, L.R., Green, A.R., Haddock, G.H., Hagood, A.R., Johnson, A.M., Mc Murray, J.M., Russel1, R.G., and Weeden, D.A., 1967, Geologic map of the Owyhee region, Malhuer County, Oregon: University of Oregon Museum of Natural History Bulletin, 8, scale $1: 125,000$.

Lawrence, R.D., 1976, Strike-slip faulting terminates the Basin and Range Province in Oregon: Geological Society of America Bulletin, v. 87 , no. 6, p. $846-850$.

Larson, K., and Couch, R., 1975, Preliminary gravity maps of the Vale area, Malhuer County,Oregon: The Ore Bin, v. 37, no. 7 , p. $138-142$.

Lillie, R.J., Subsurface geologic structure of Vale, Oregon KGRA: thesis, M.S., Oregon State University, Corvallis, Oregon.

Lindgren, W., 1898, The mining districts of the Idaho basin and the Boise Ridge, Idaho: U.S. Geological Survey, 18 th Annual Report, part 3, p. $617-744$.

Malde, H.E., and Powers, H.A., 1962, Upper Cenozoic stratigraphy of weatern Snake River plain, Idaho: Geological Society of America Bulletin, v. 73, p. 1197 - 1220 .

Mariner, R.H., Rapp, J.B., Willey, L.M., and Presser, T.S., 1974, The chemical compostion and estimated minimum thermal reservoir temperatures of selected hot springs in Oregon: U.S. Geological Survey, Open - File Report, 27 p.

Newton, V.C. Jr., and Corcoran, R.E., 1963, Petroleum geology of the western Snake River basin, Oregon-Idaho: Oregon Department of geology and Mineral Industries $0 i l$ and Gas Investigations $1,67 \mathrm{p}$.

Renick, B.C., 1930, The petrology and geology og a portion of Malhuer County, Oregon: Journal of Geology, v. 38, p. 481 520

Storm, B.A., 1975, Stratigraphy and petrology of the Grassy Mountain Formation, Malhuer County, Oregon: unpublished thesis, M.S., University of Oregon, Eugene, Oregon, 63 p. 
Telford, W.M., Geldart, L.P., Sheriff, R.S., and Keys, D.A., 1976, Applied geophysics: Cambridge, Cambridge University Press

Thiruvathukal, J.V, Berg, J.W., and Heinrichs, D.F., 1970, Regional gravity of Oregon: Geological Society of America Bulletin, v. 81 , no. 3, p. $725-738$.

Van Blaricon, R., Ed., 1980, Practical geophysics for the exploration geologist: Spokane, Northwest Mining Association. 


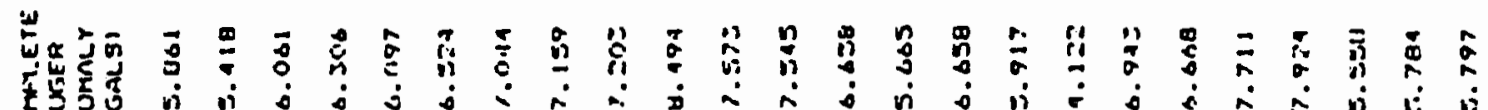

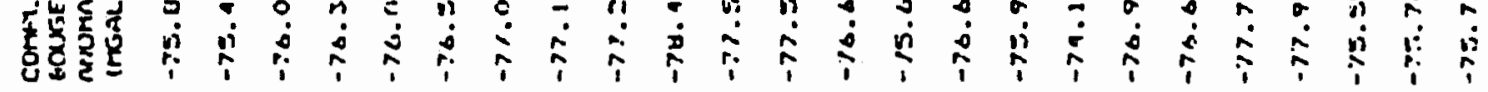

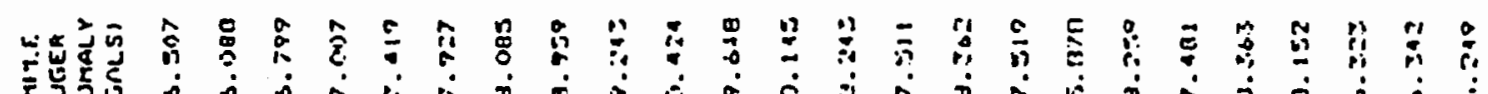

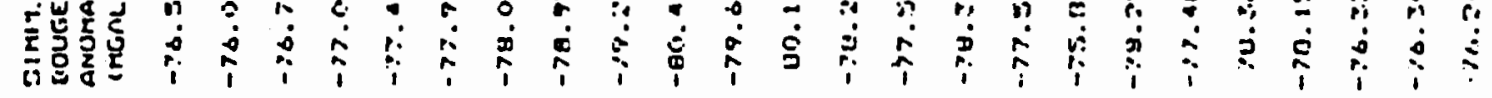

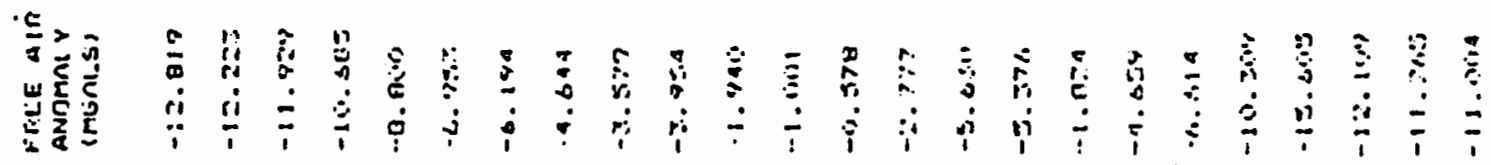

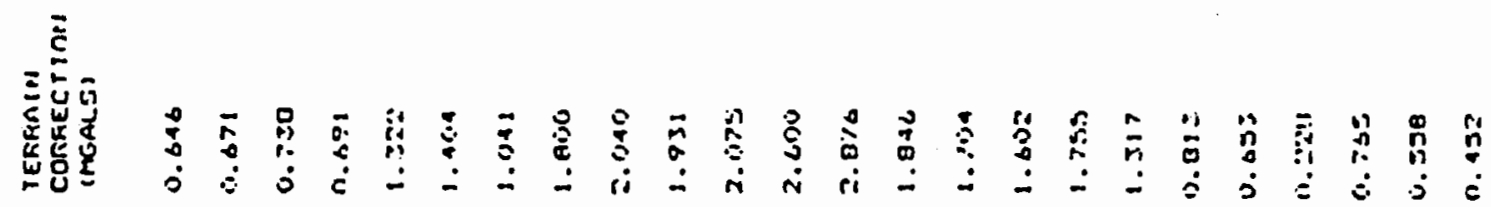

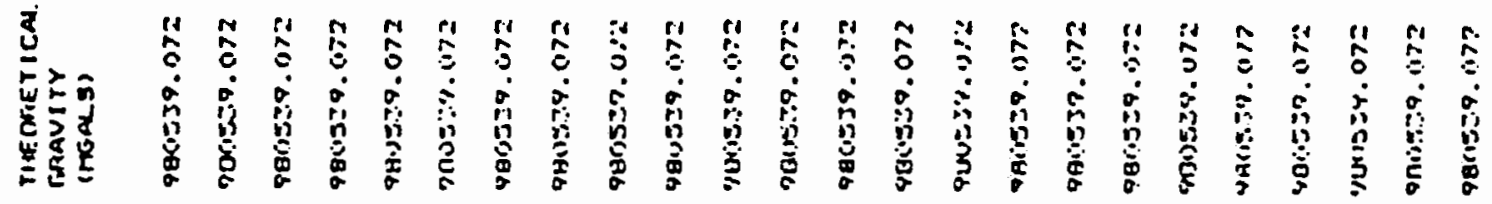

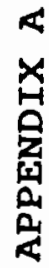

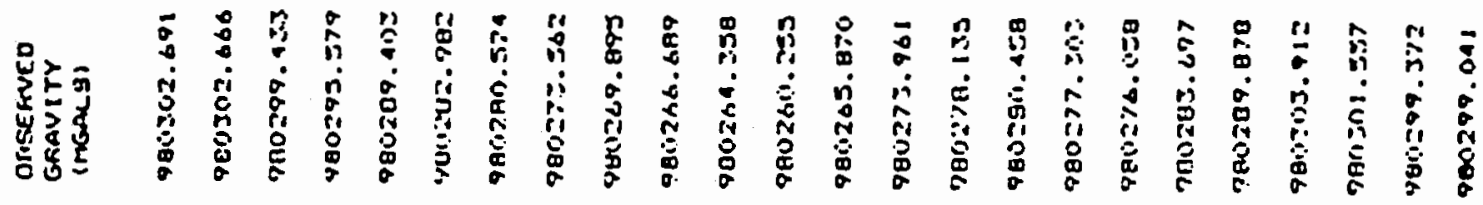

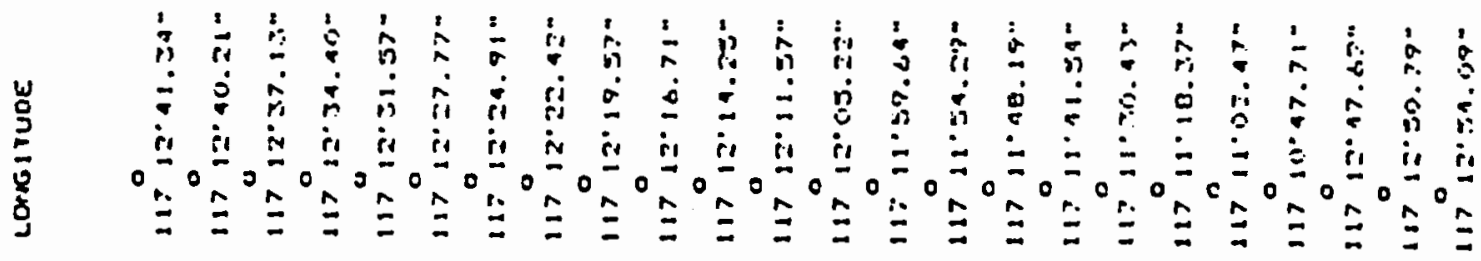
b)

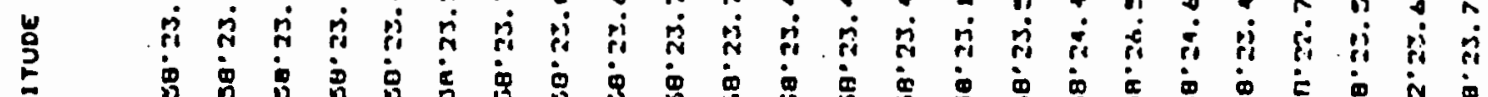

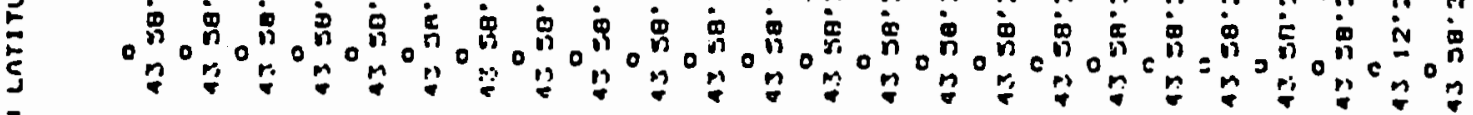

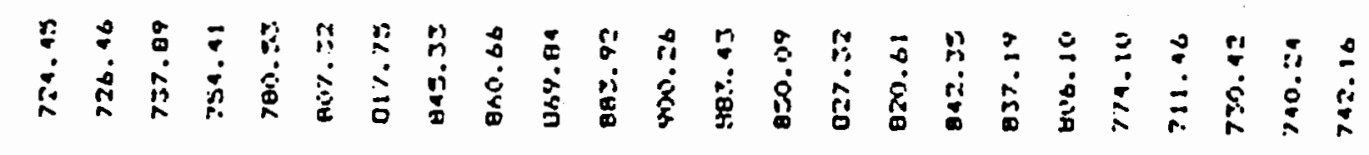

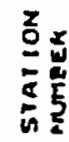

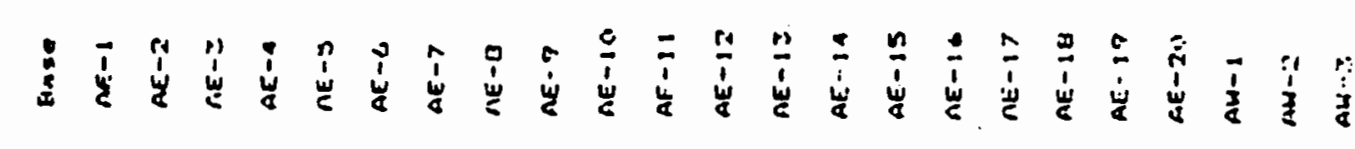




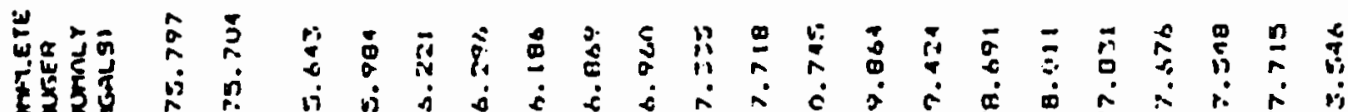

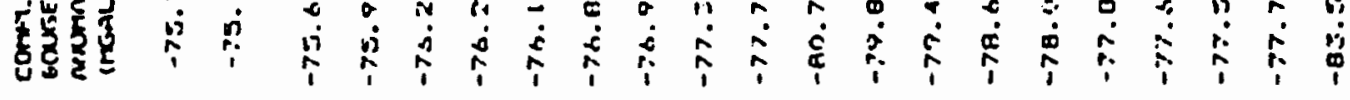

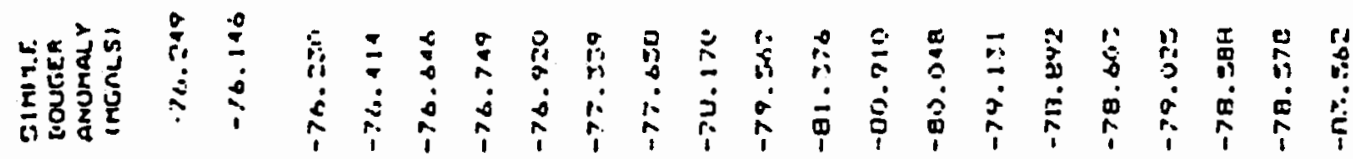

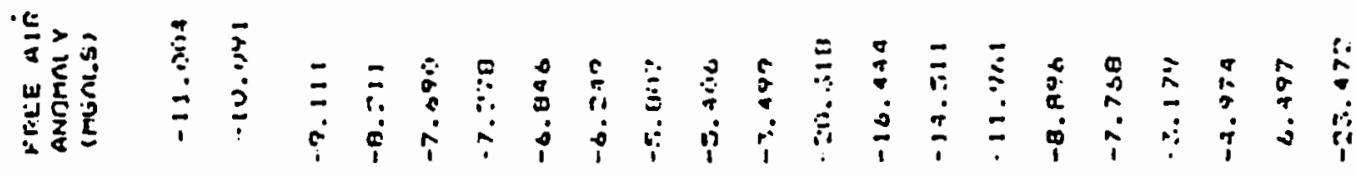

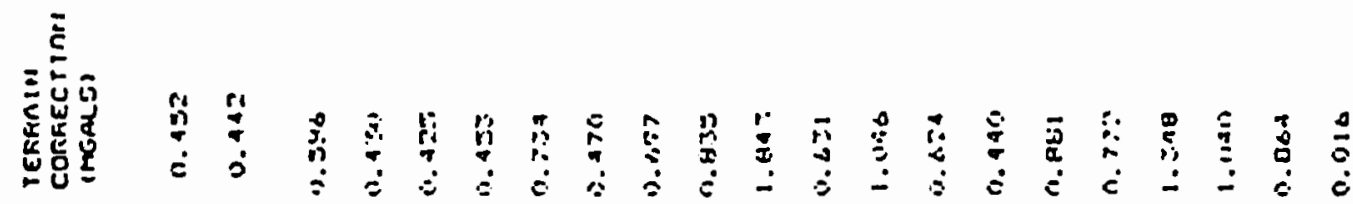

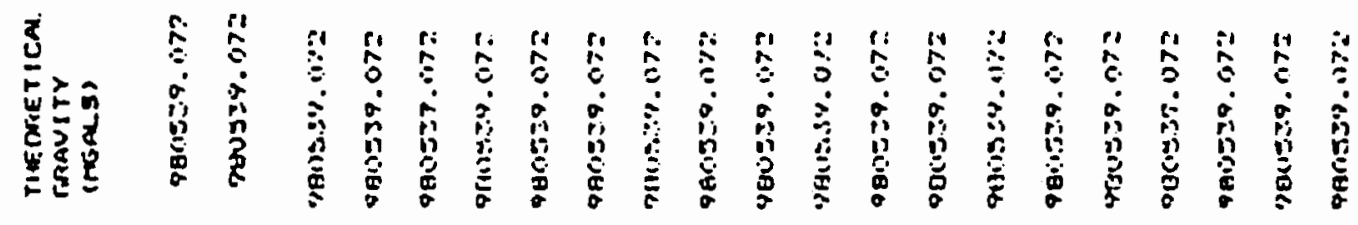

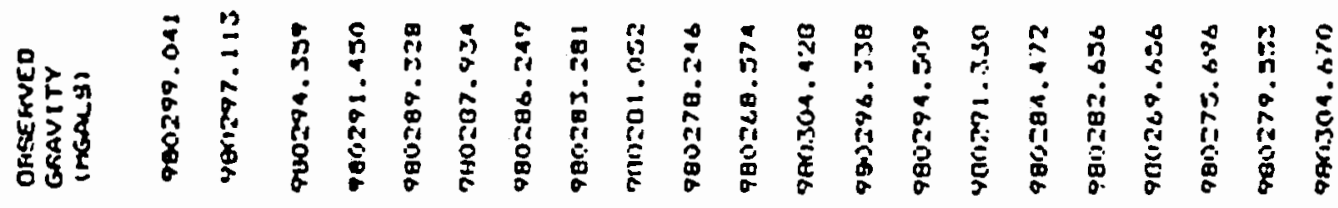

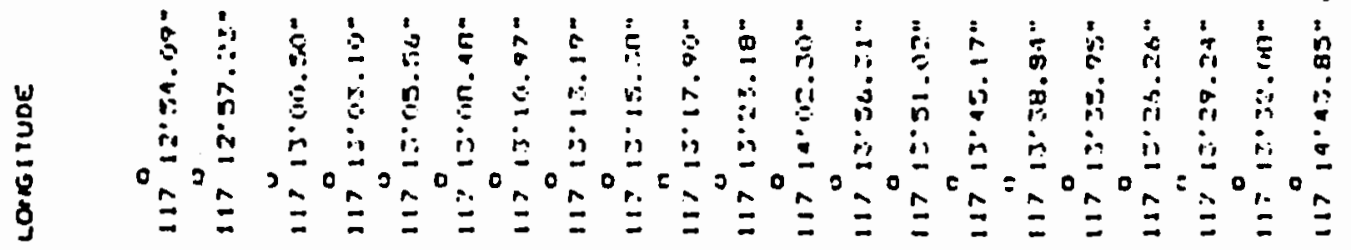

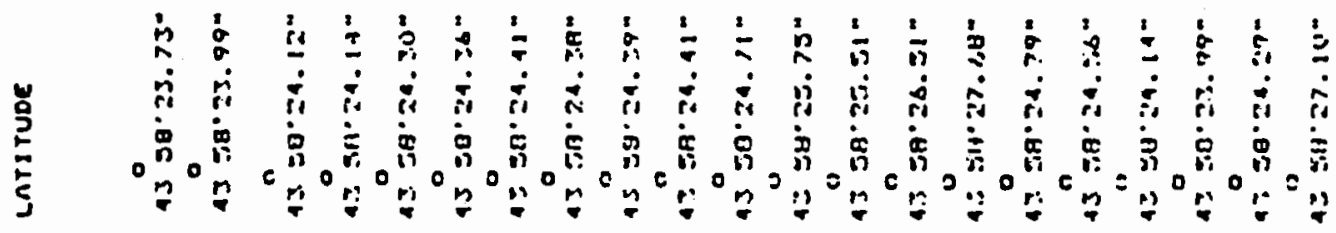

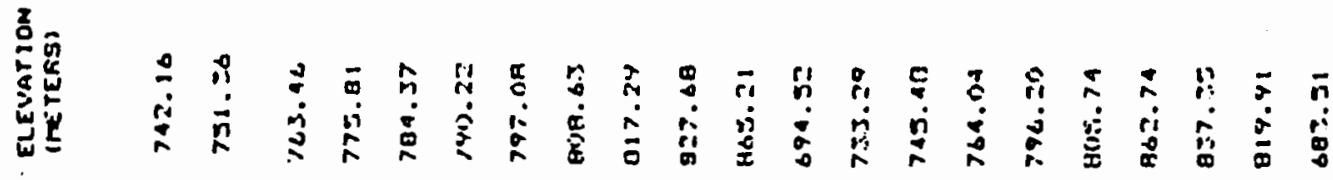

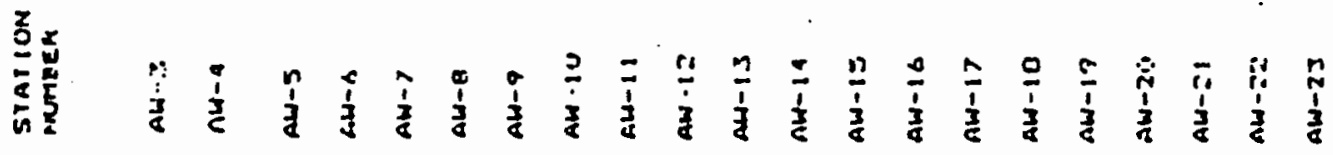




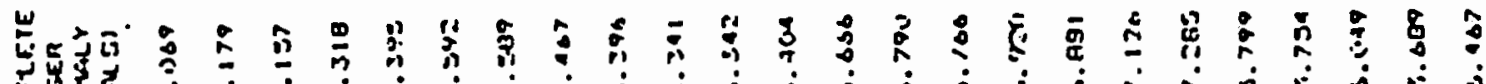

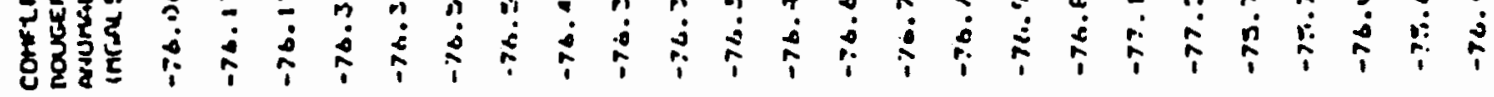

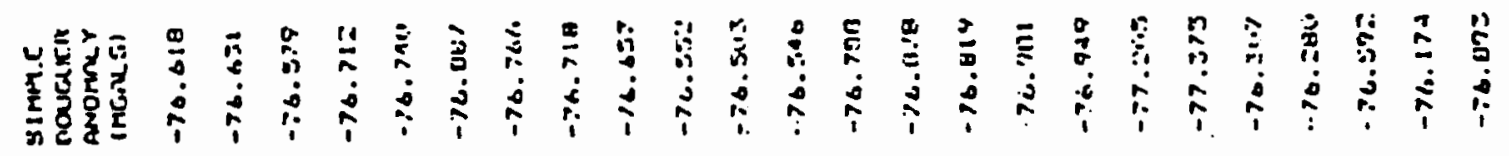

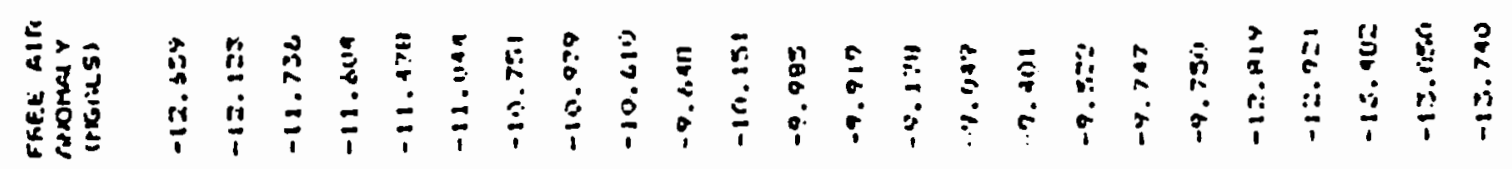

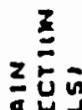

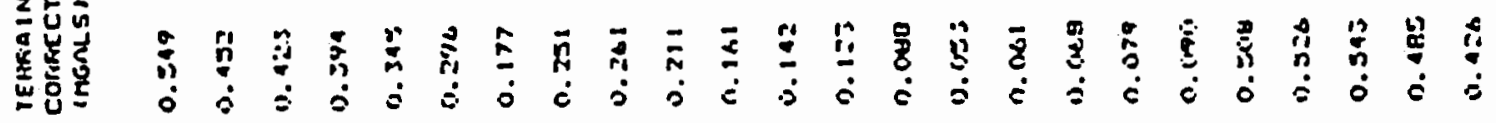

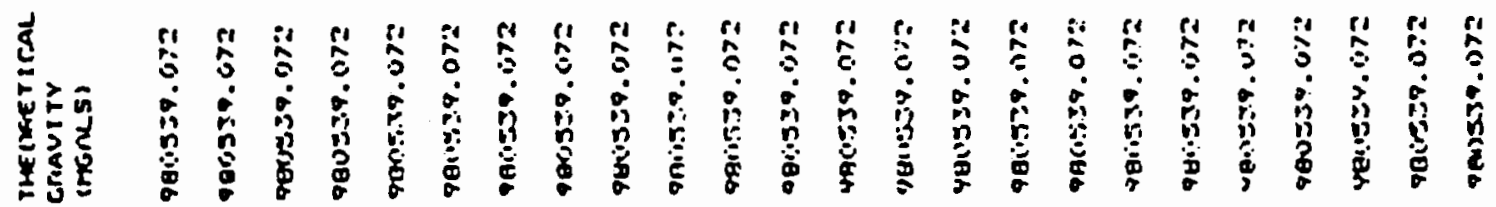

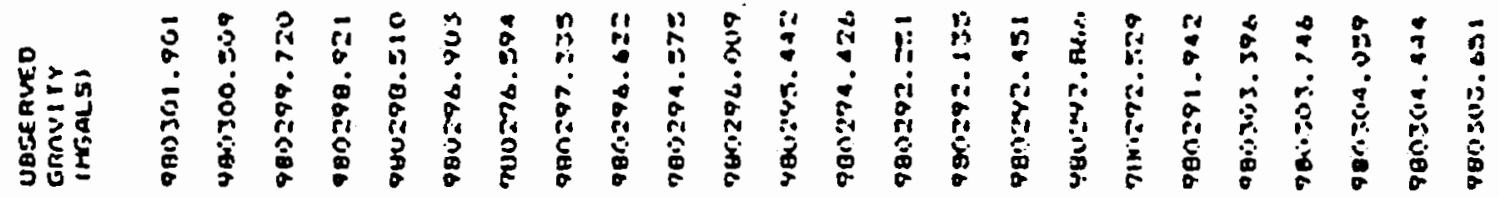
当它

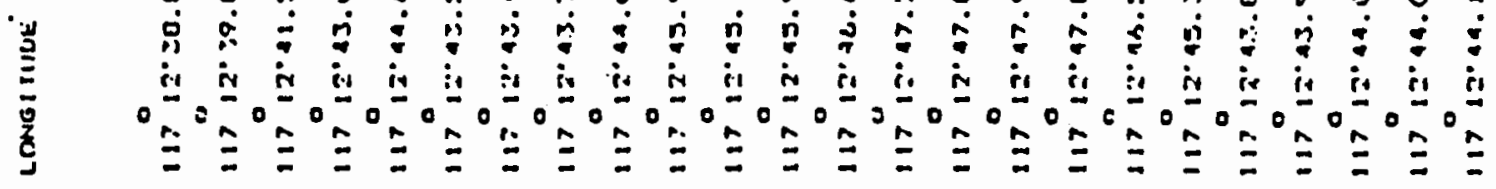
\&

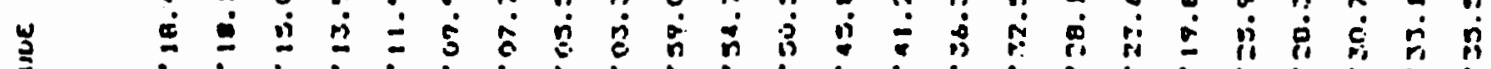

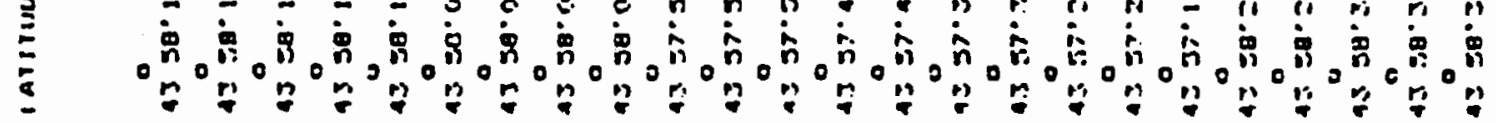

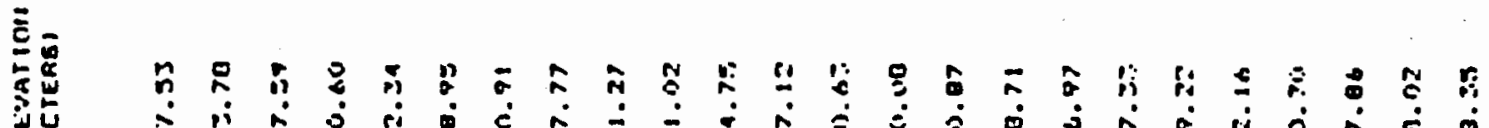

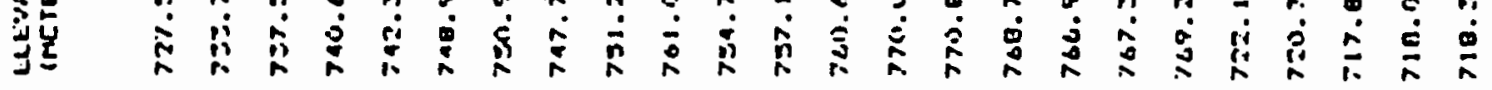

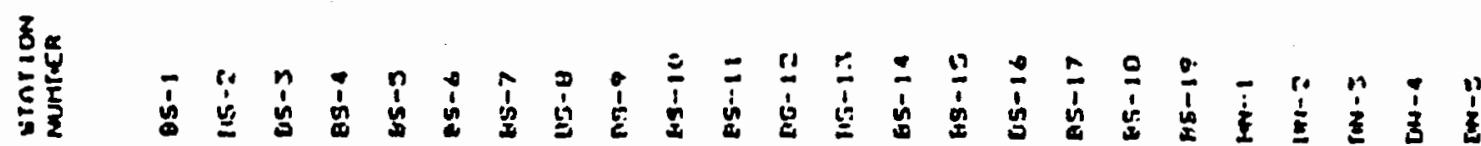




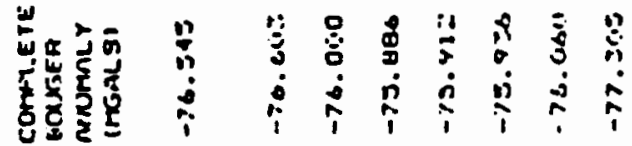

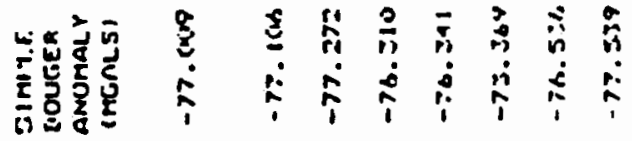

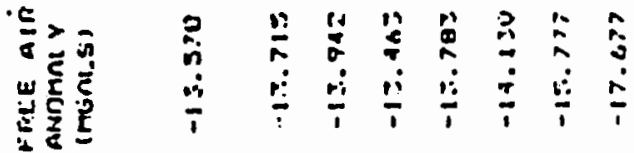

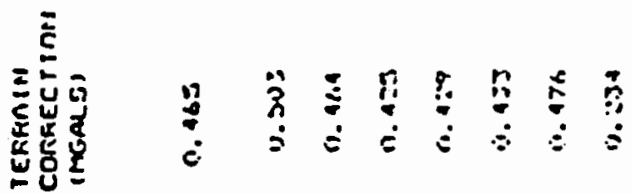

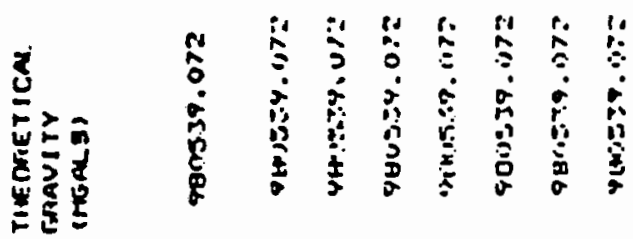

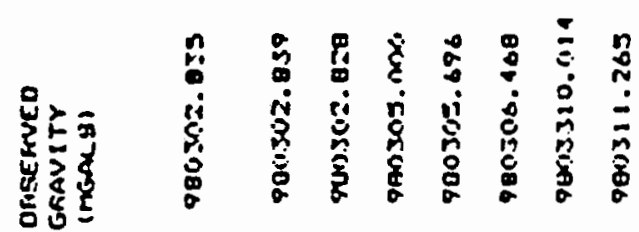

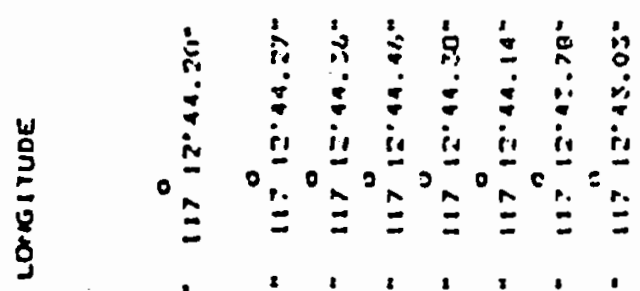

क

帘

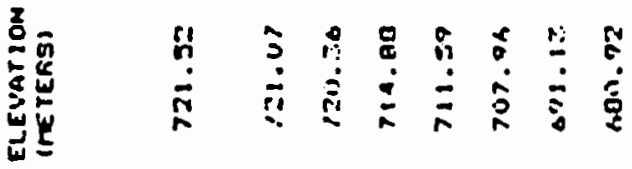

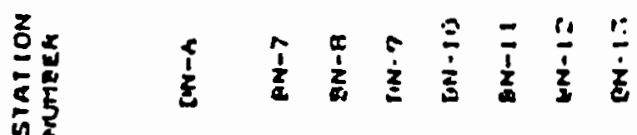




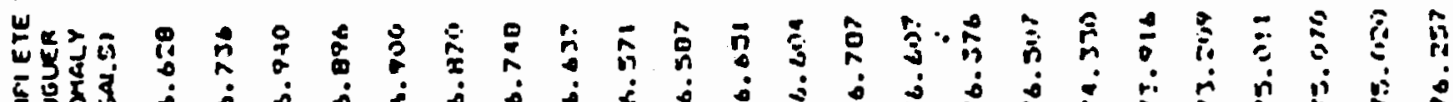

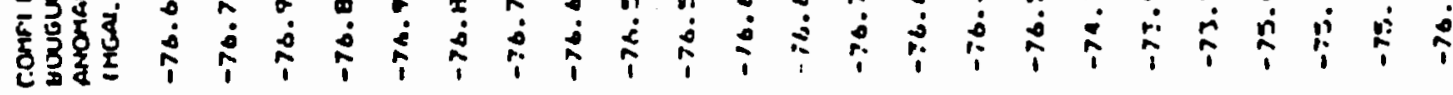

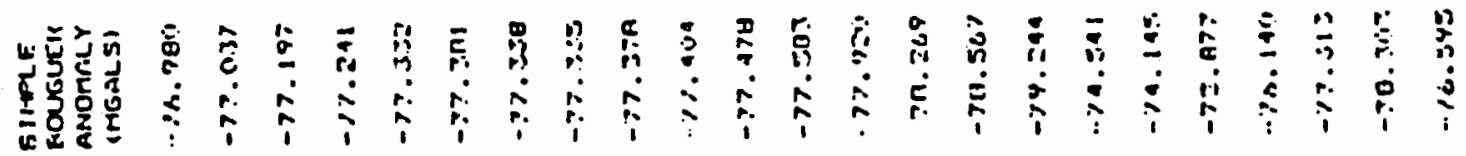

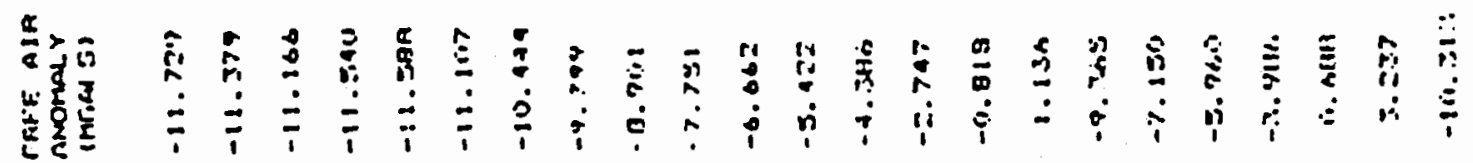

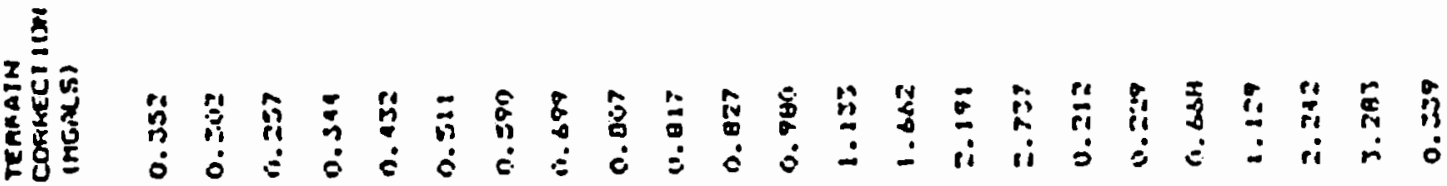

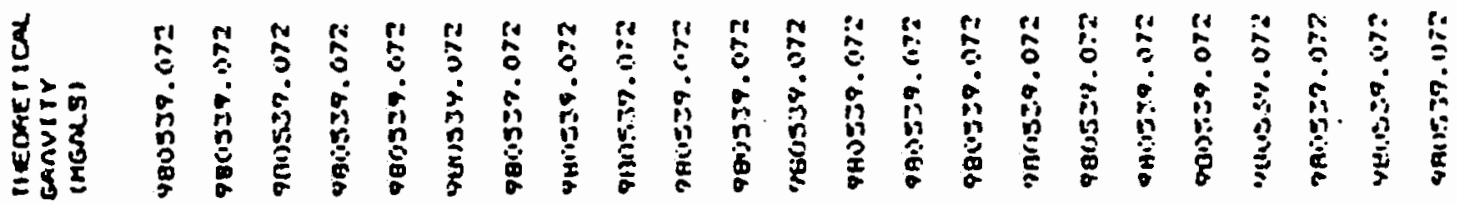

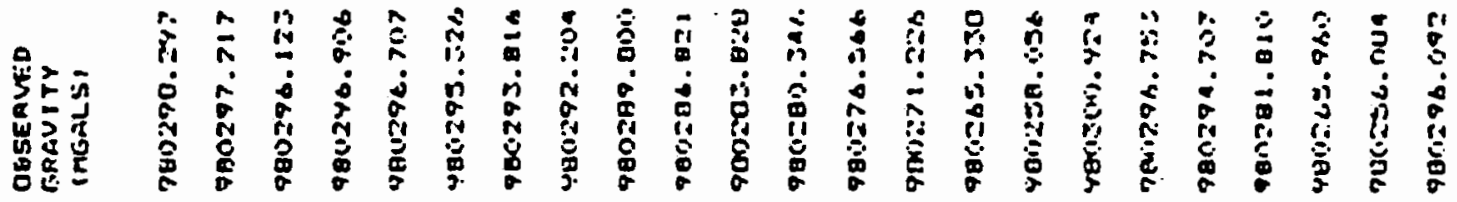

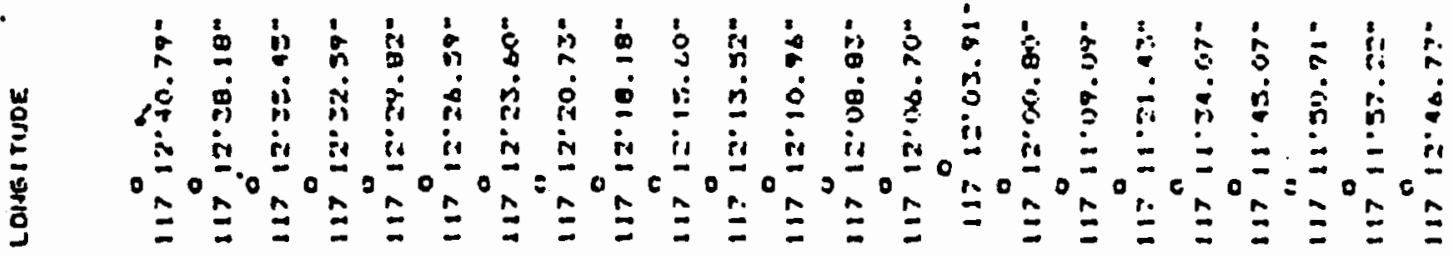
3 罚

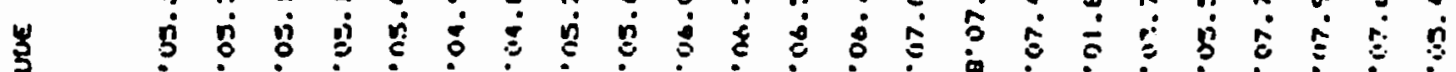

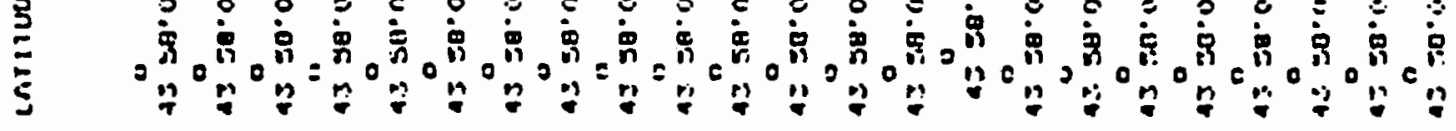

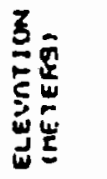

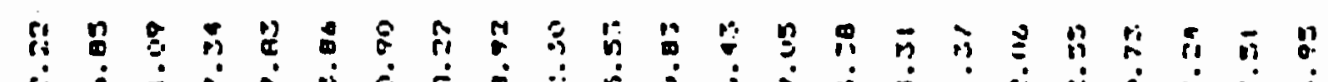

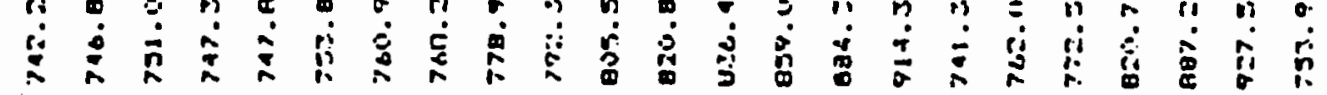

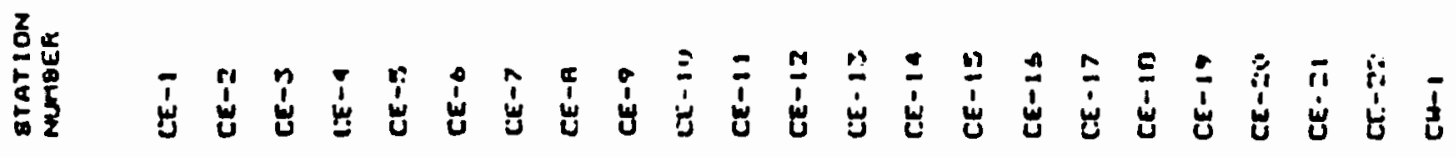




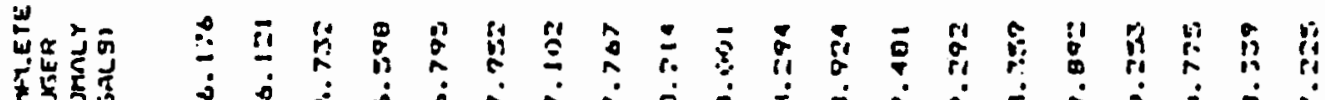

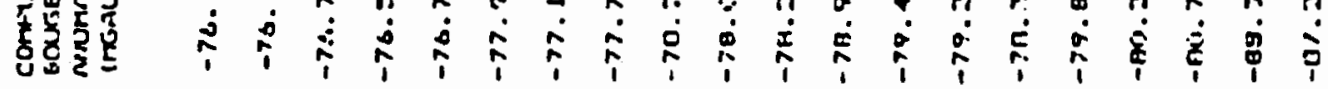

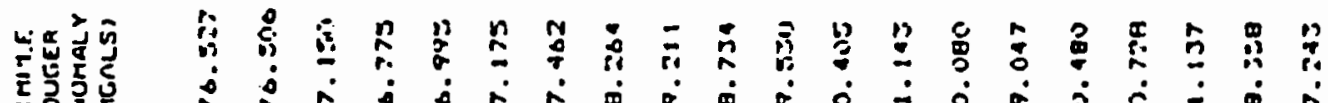

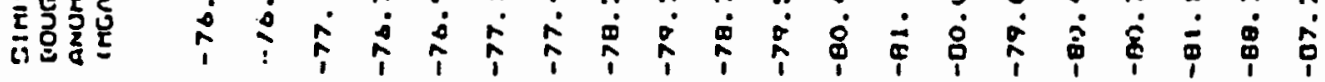

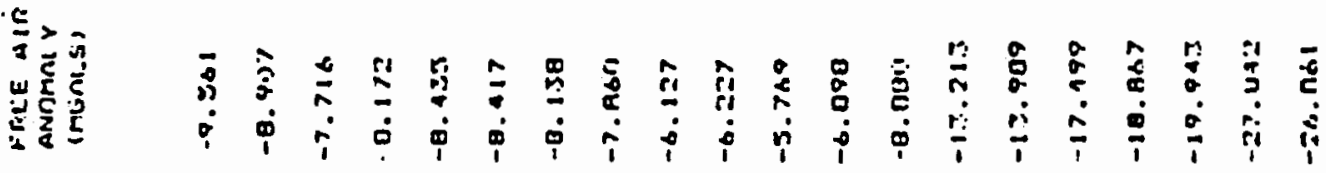

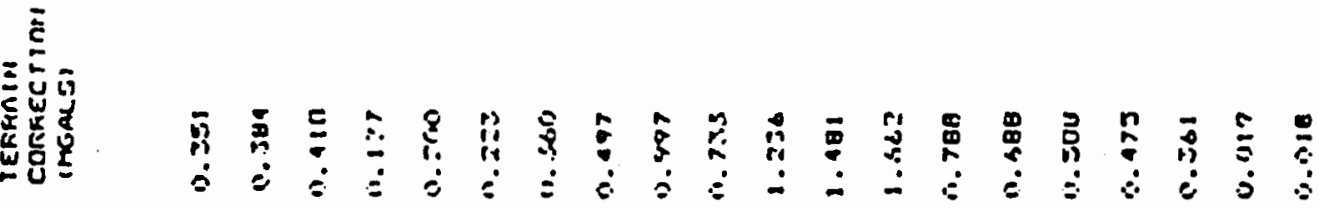

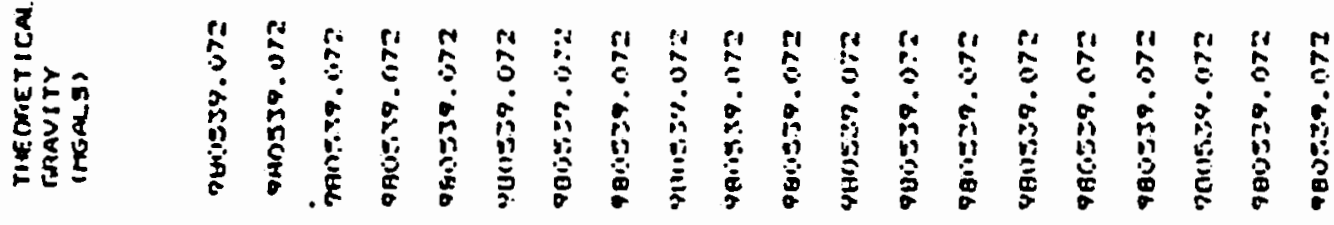

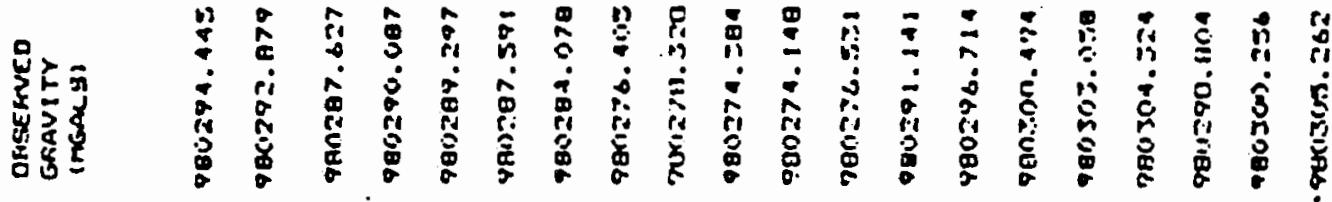

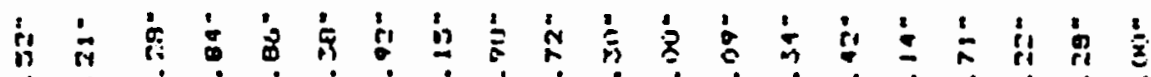

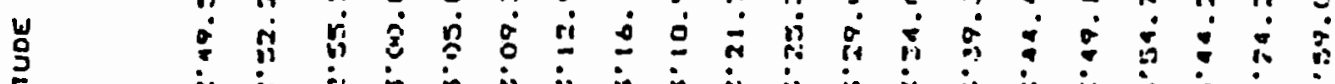
0
$g$

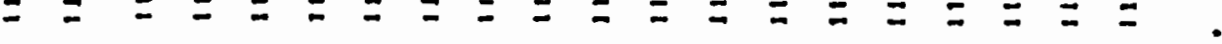

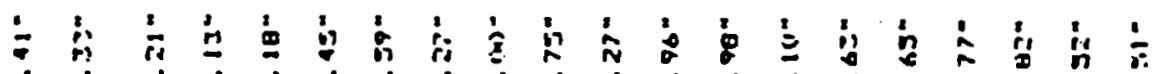

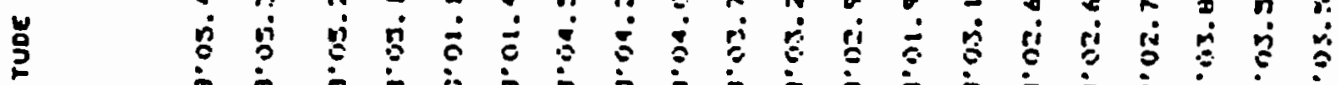
药

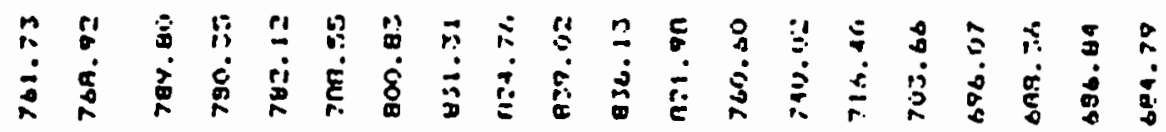

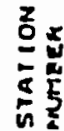

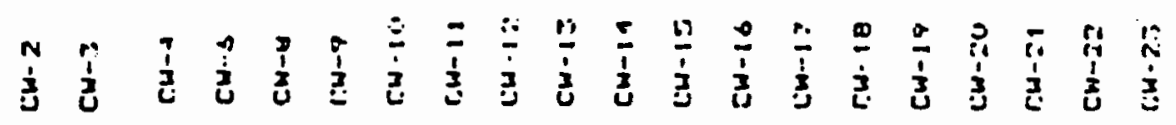




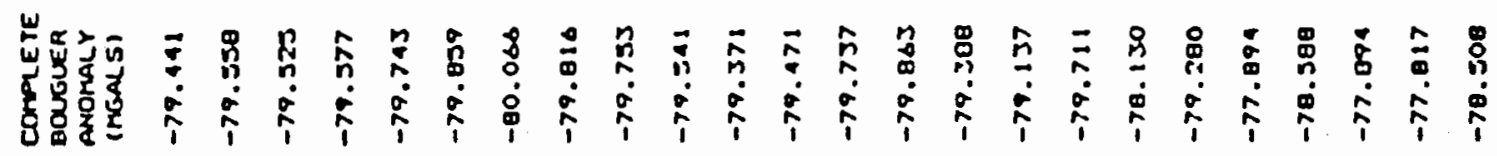

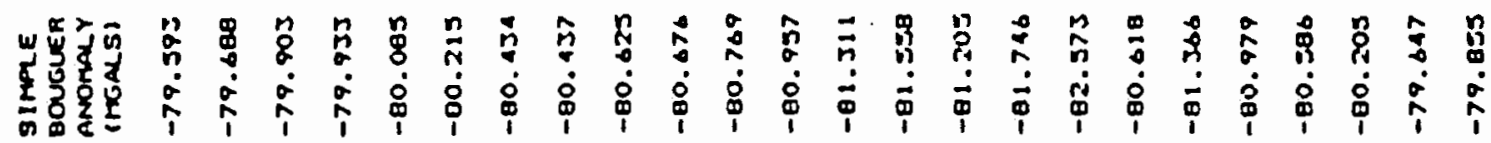

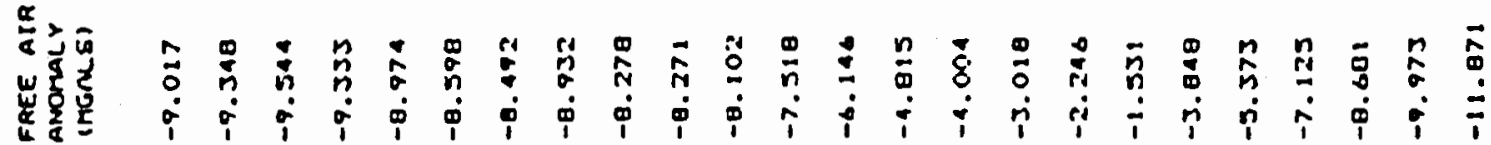

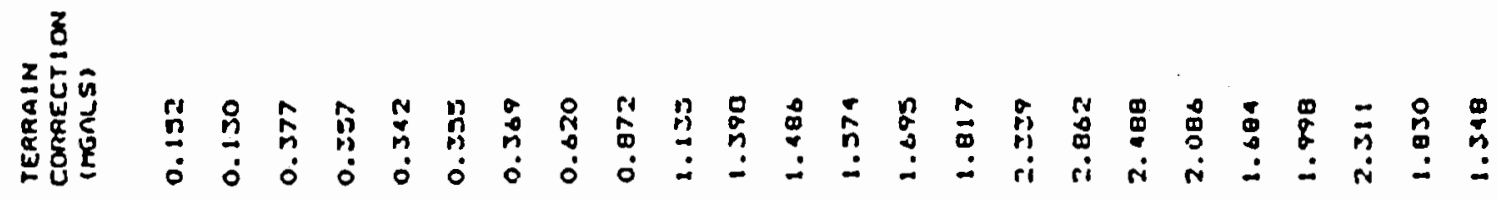

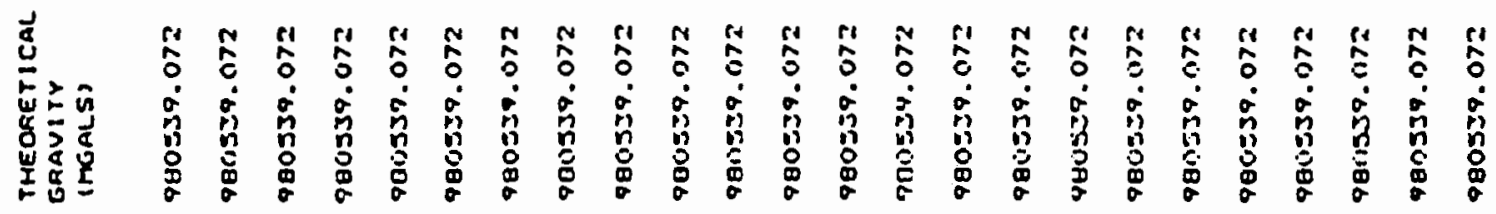

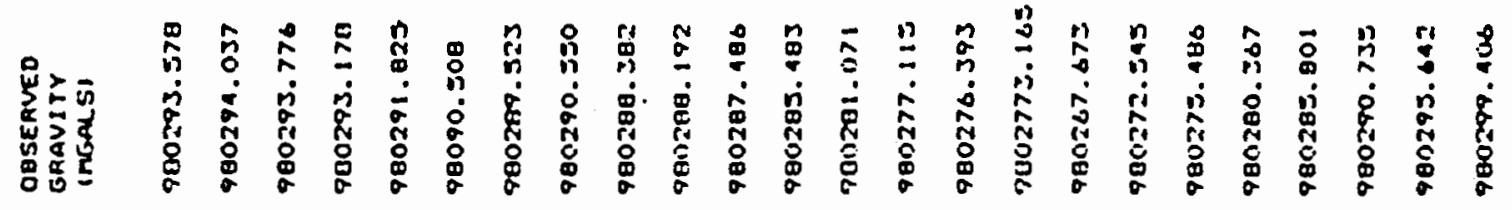

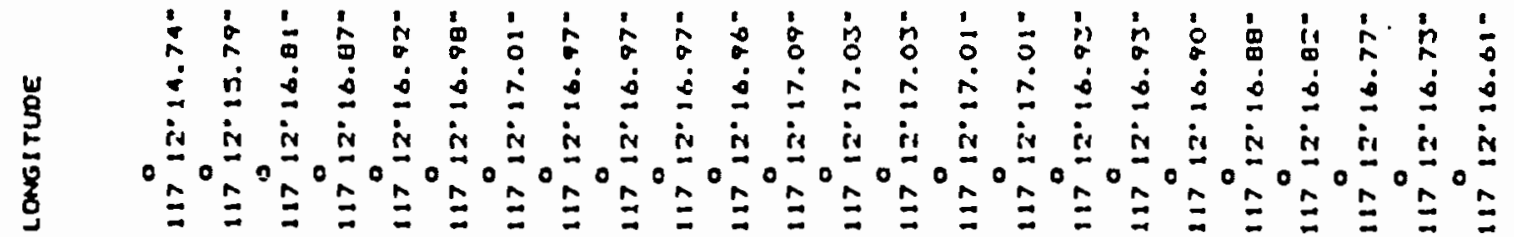

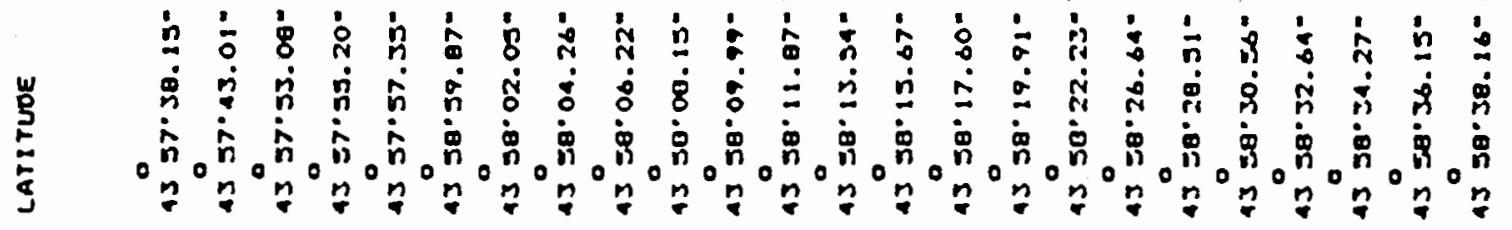
站

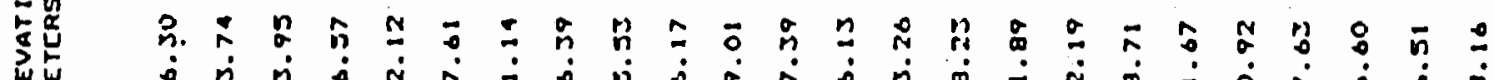

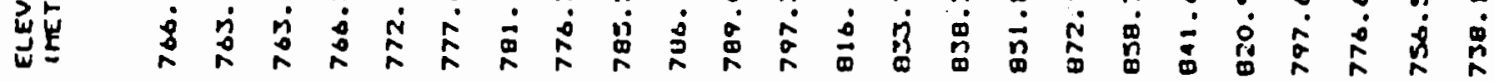

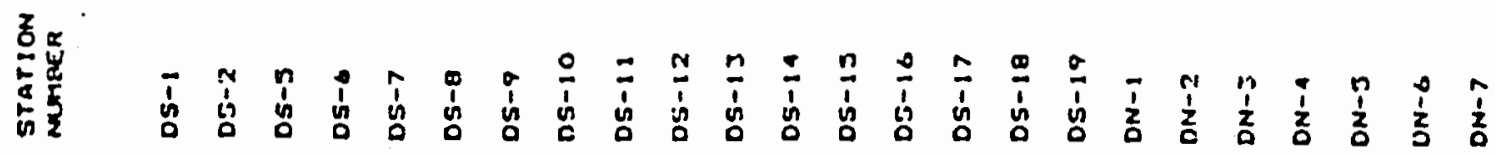




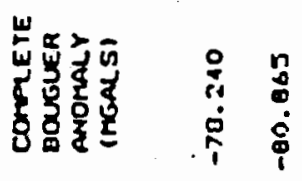

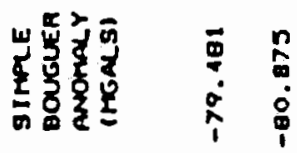

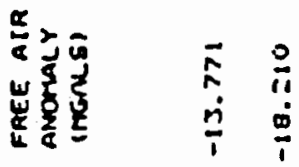

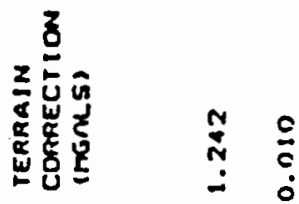

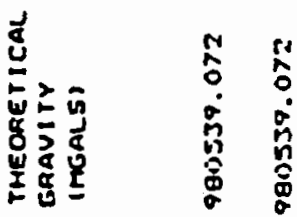

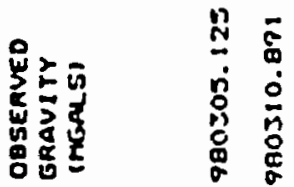

J

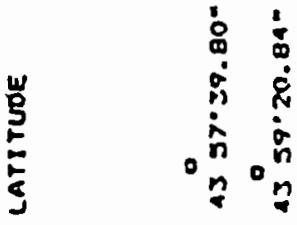

总热

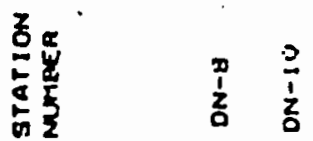




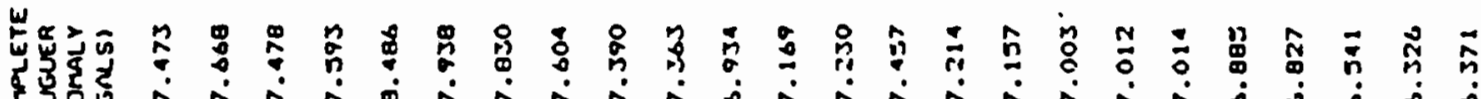

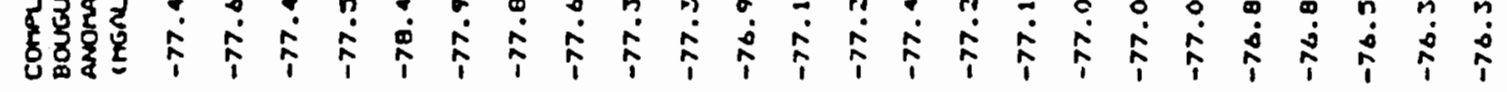

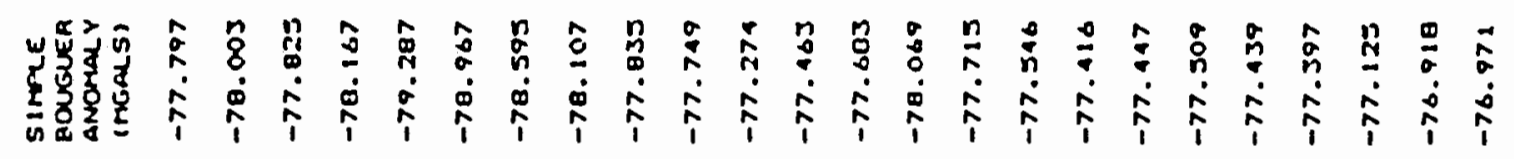

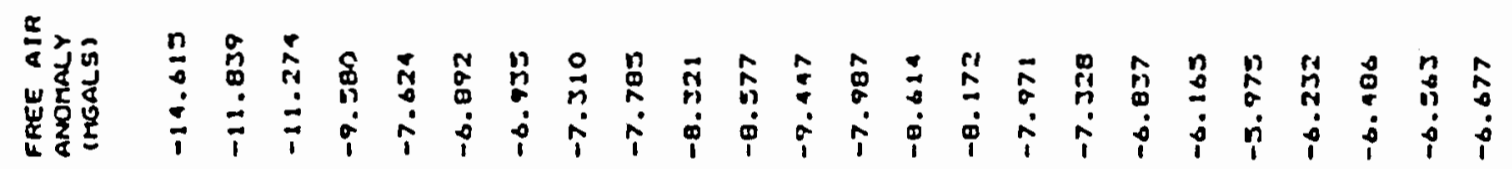

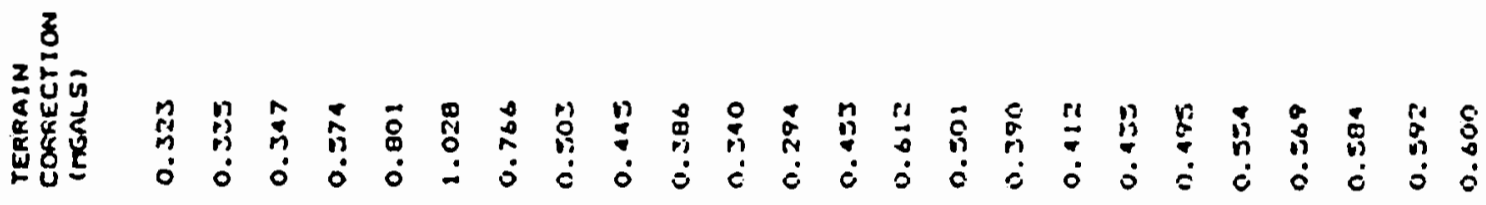

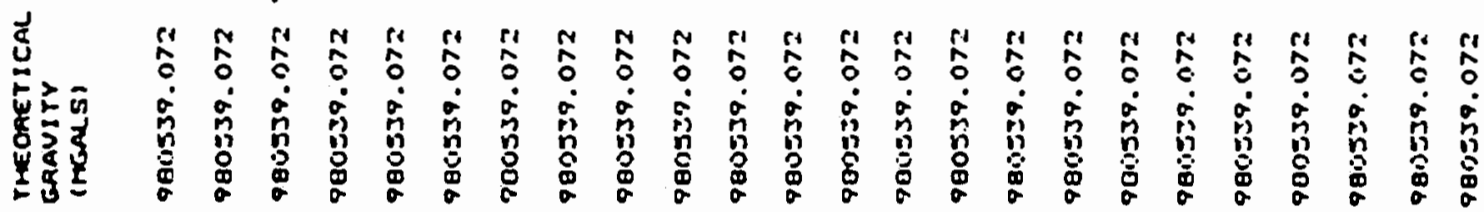

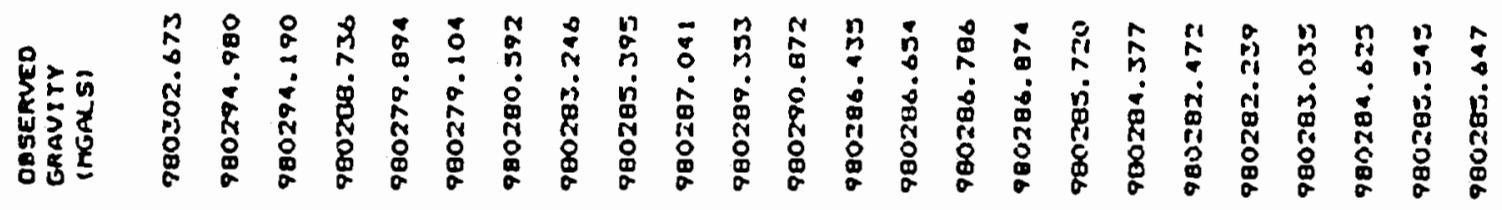

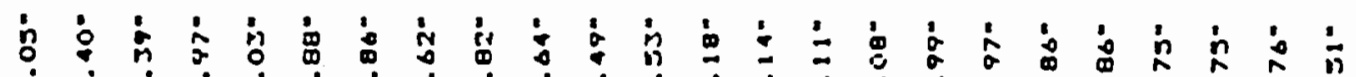

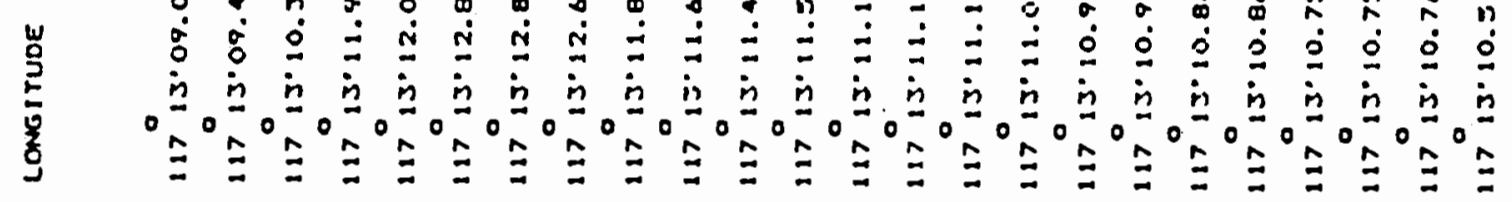

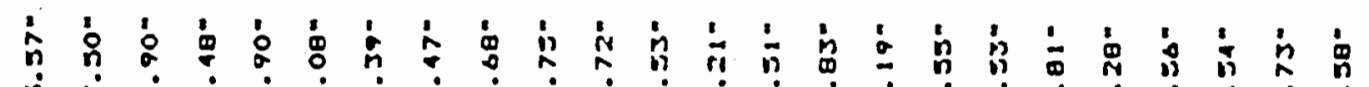

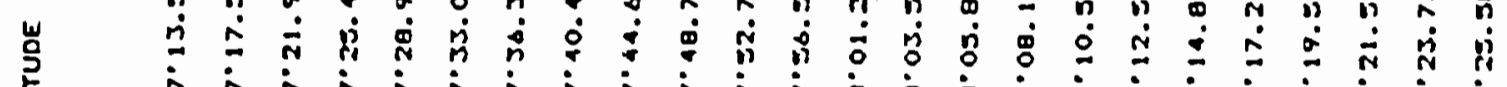

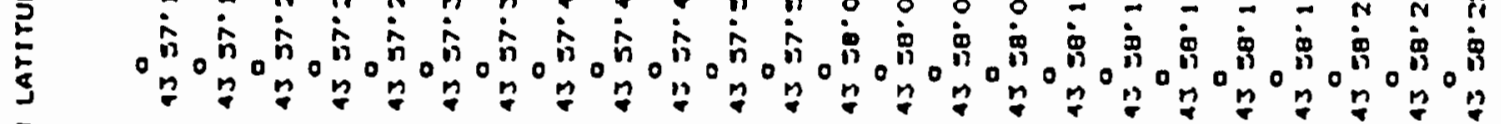
定要

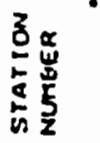

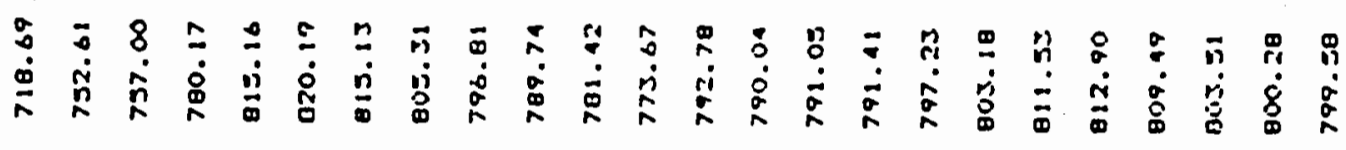

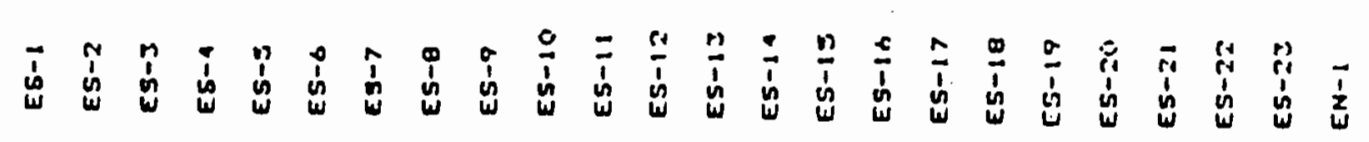




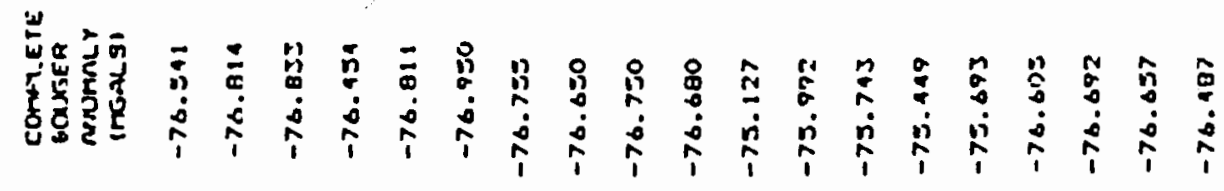

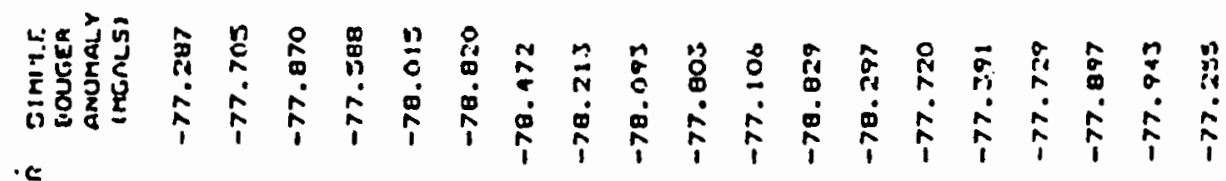

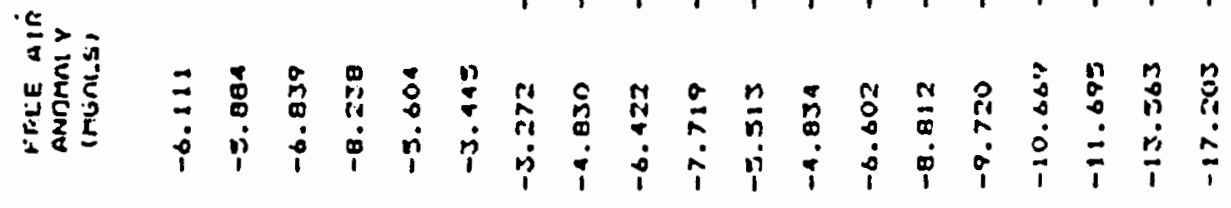

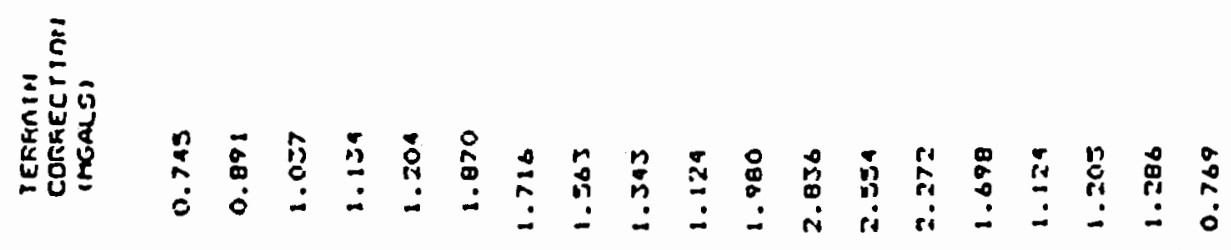

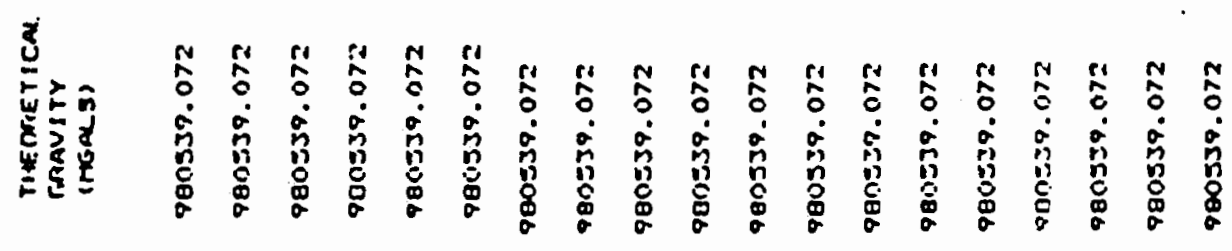

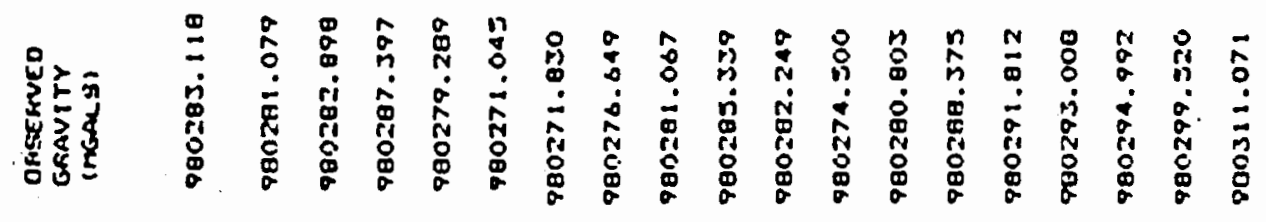

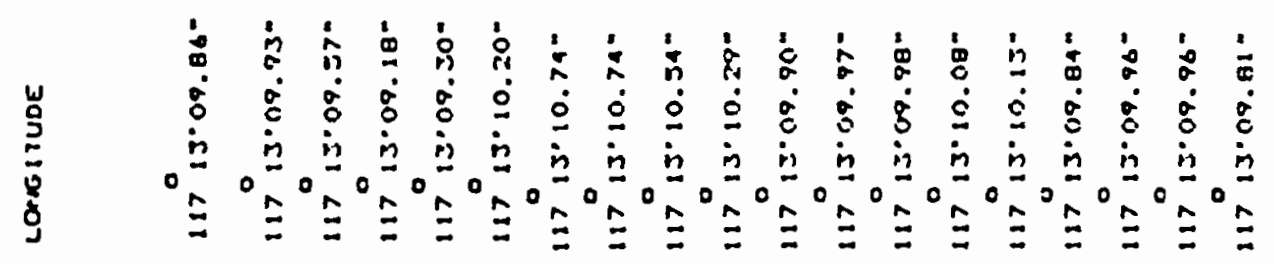

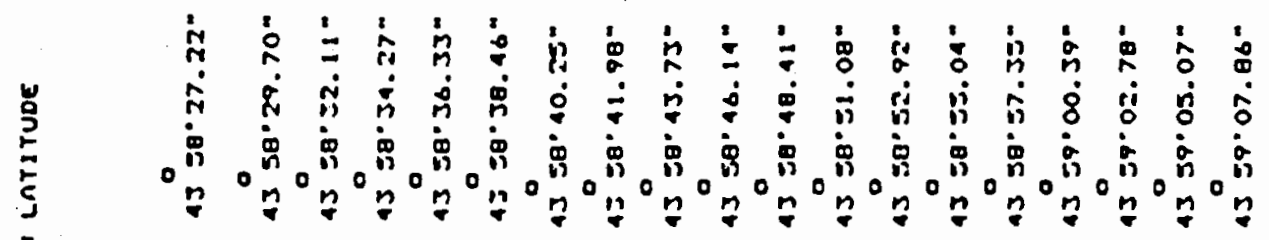

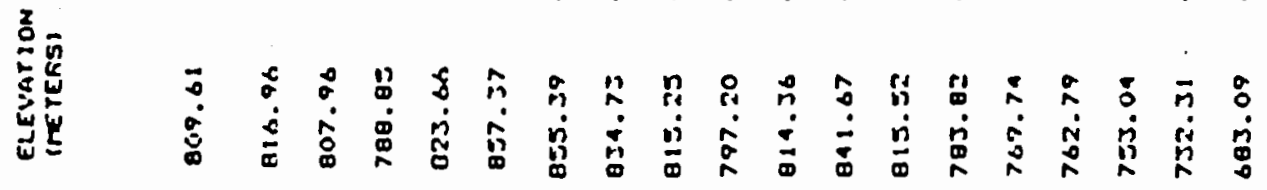

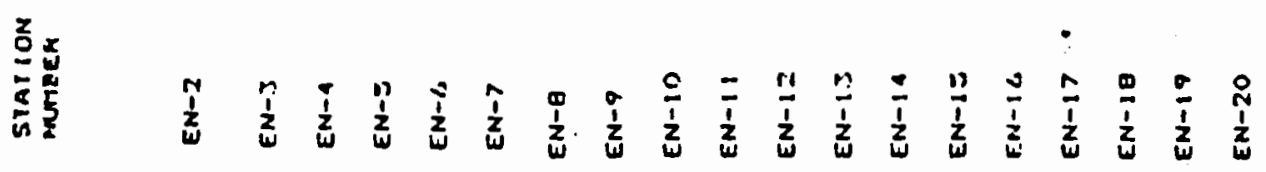




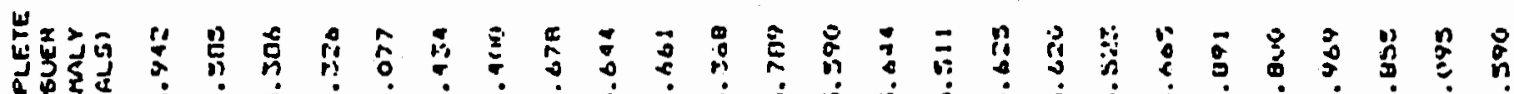

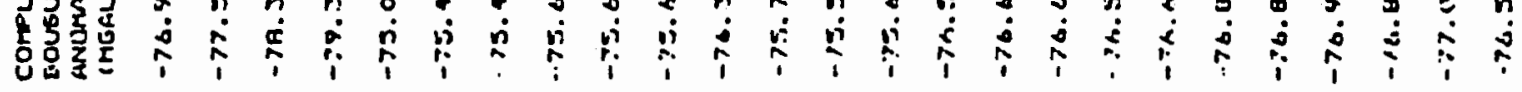

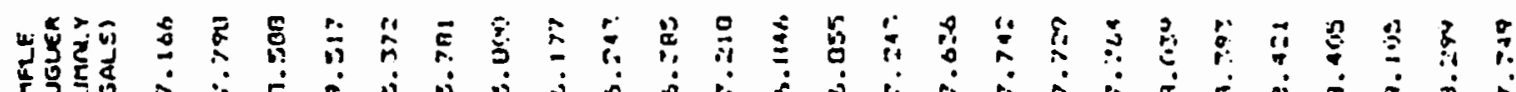

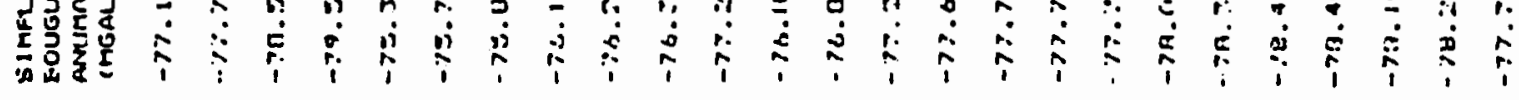

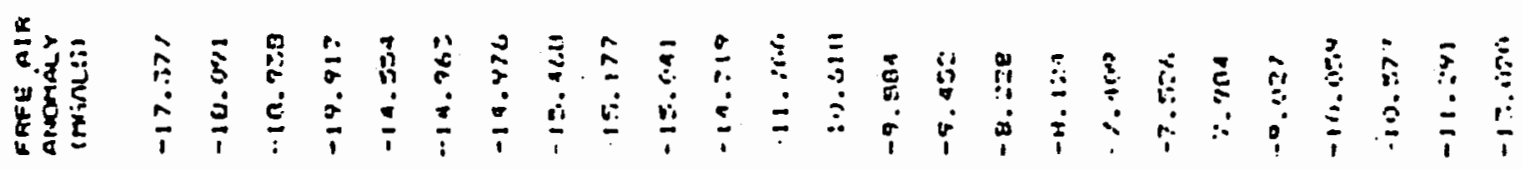

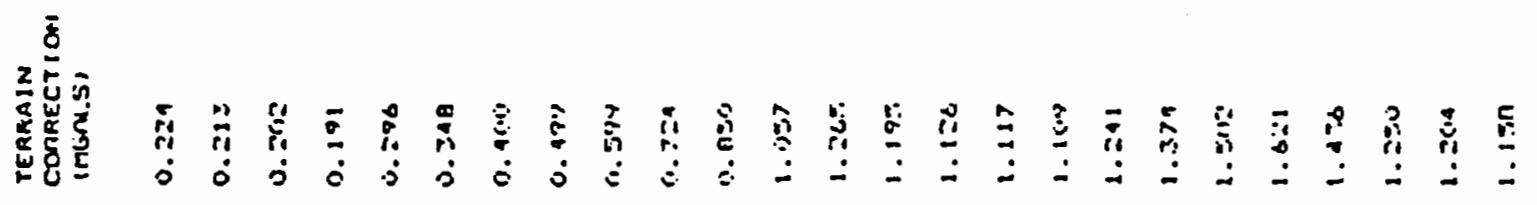

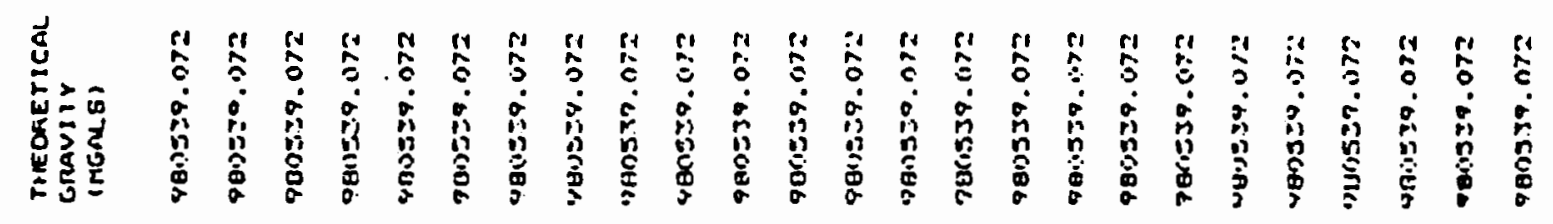

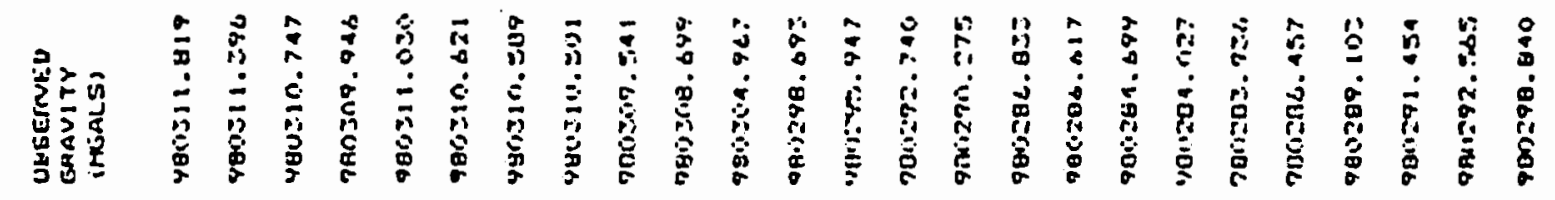

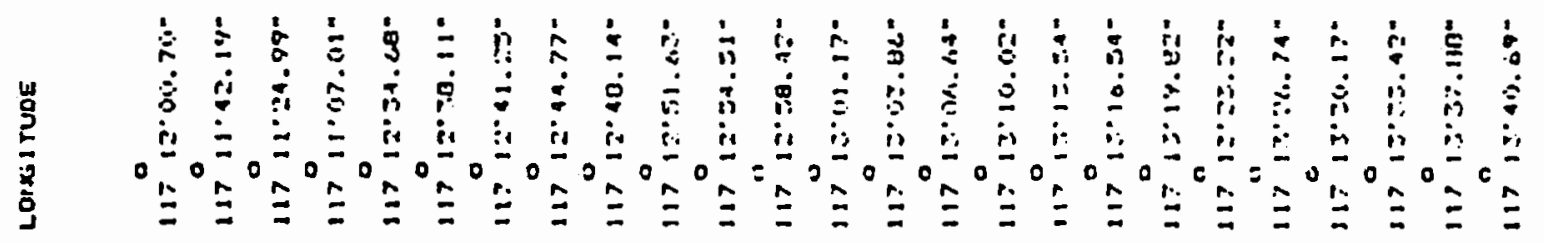

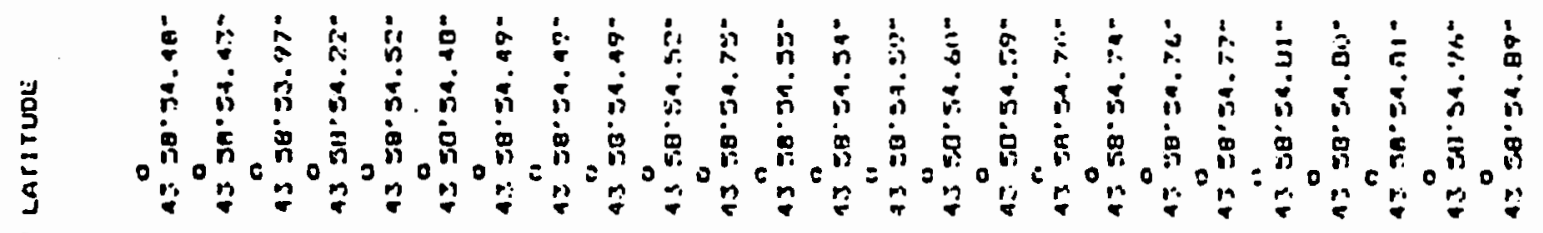

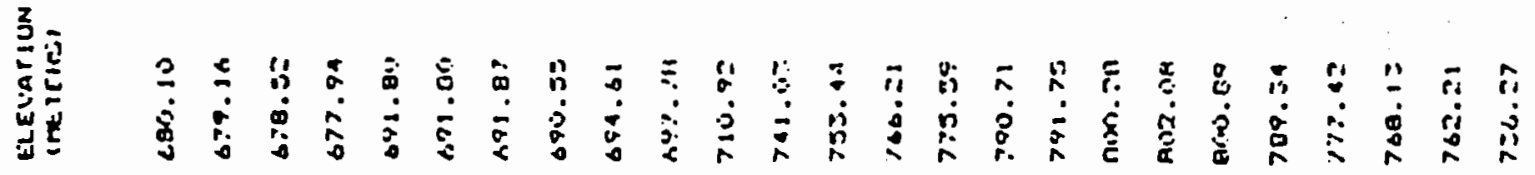

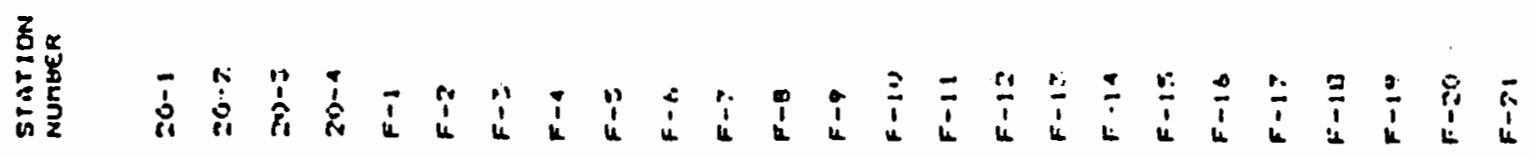




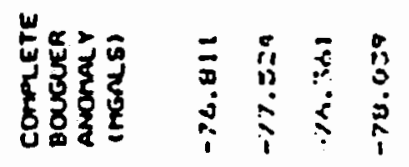

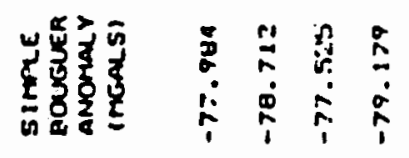

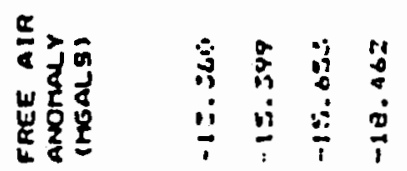

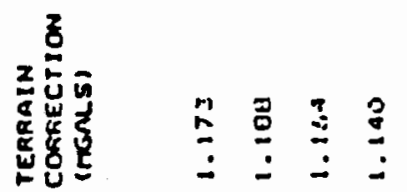

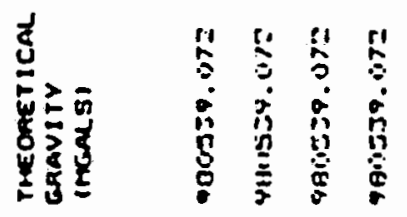

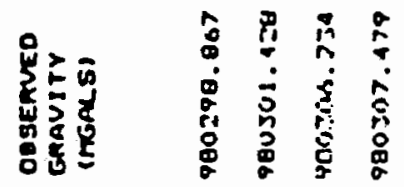

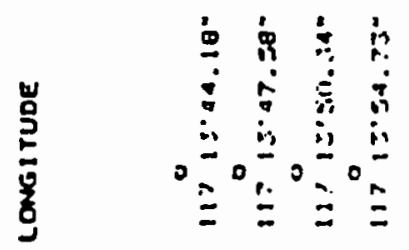

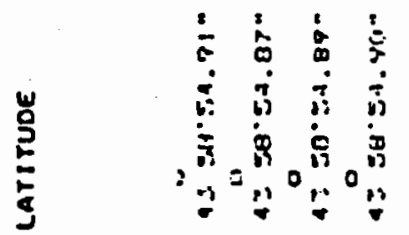

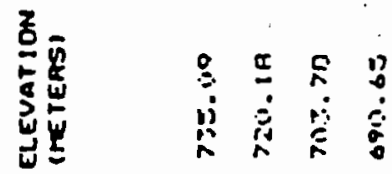

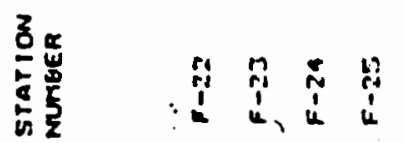


APPENDIX B

\begin{tabular}{|c|c|c|c|c|c|c|c|}
\hline Station & Gammas & Station & Gammas & Station & Gammas & Station & Gammas \\
\hline Base & 55,742 & & & & & & \\
\hline B I & 55,750 & $\mathrm{C} 1$ & 55,517 & Dl & 55,742 & El & 55,747 \\
\hline B2 & 55,751 & $\mathrm{C} 2$ & 55,428 & D2 & 55,768 & E2 & 55,746 \\
\hline B3 & 55,755 & C3 & 55,476 & D3 & 55,778 & E3 & 55,743 \\
\hline B4 & 55,756 & $C 4$ & 55,589 & D4 & 55,762 & E4 & 55,738 \\
\hline B5 & 55,739 & $\mathrm{C} 5$ & 55,630 & D5 & 55,750 & E5 & 55,748 \\
\hline B6 & 55,751 & c6 & 55,619 & D6 & 55,757 & E6 & 55,759 \\
\hline B7 & 55,753 & $\mathrm{C7}$ & 55,539 & D7 & 55,689 & E7 & 55,746 \\
\hline B8 & 55,746 & $\mathrm{C} 8$ & 55,653 & D8 & 55,655 & E8 & 55,751 \\
\hline B9 & 55,739 & C9 & 55,651 & D9 & 55,641 & E9 & 55,731 \\
\hline B10 & 55,734 & $\mathrm{ClO}$ & 55,647 & D10 & 55,626 & E10 & 55,724 \\
\hline B11 & 55,731 & $\mathrm{C} 11$ & 55,645 & D11 & 55,641 & E11 & 55,715 \\
\hline B12 & 55,730 & $\mathrm{C} 12$ & 55,659 & D12 & 55,636 & $E 12$ & 55,708 \\
\hline B 13 & 55,737 & $\mathrm{C} 13$ & 55,611 & D13 & 55,636 & E13 & 55,705 \\
\hline B 14 & 55,732 & $\mathrm{C} 14$ & 55,629 & D14 & 55,624 & E14 & 55,695 \\
\hline B15 & 55,730 & C15 & 55,642 & D15 & 55,650 & E 15 & 55,695 \\
\hline B16 & 55,727 & $\mathrm{Cl6}$ & 55,645 & D16 & 55,670 & E16 & 55,673 \\
\hline B17 & 55,735 & $\mathrm{C} 17$ & 55,638 & D17 & 55,692 & E17 & 55,681 \\
\hline B18 & 55,739 & $\mathrm{C} 18$ & 55,662 & D18 & 55,726 & E 18 & 55,680 \\
\hline B19 & 55,731 & C19 & 55,656 & D19 & 55,754 & E19 & 55,658 \\
\hline B20 & 55,733 & $\mathrm{C} 20$ & 55,676 & D20 & 55,778 & E.20 & 55,670 \\
\hline B21 & 55,752 & $\mathrm{C} 21$ & 55,688 & D21 & 55,770 & E21 & 55,661 \\
\hline B22 & 55,760 & $\mathrm{C} 22$ & 55,687 & D22 & 55,783 & E22 & 55,643 \\
\hline B23 & 55,764 & $\mathrm{C} 23$ & 55,697 & D23 & 55,784 & E23 & 55,660 \\
\hline B24 & 55,772 & $\mathrm{C} 24$ & 55,706 & D24 & 55,789 & E24 & 55,651 \\
\hline B25 & 55,771 & $\mathrm{C} 25$ & 55,715 & D25 & 55,787 & E25 & 55,637 \\
\hline B26 & 55,771 & $\mathrm{C} 26$ & 55,719 & D26 & 55,754 & E26 & 55,628 \\
\hline B27 & 55,784 & $\mathrm{C} 27$ & 55,726 & D27 & 55,740 & E27 & 55,632 \\
\hline B28 & 55,787 & $\mathrm{C} 28$ & 55,719 & D28 & 55,728 & E28 & 55,622 \\
\hline B29 & 55,789 & $\mathrm{C} 29$ & 55,727 & D29 & 55,705 & E29 & 55,621 \\
\hline B30 & 55,799 & C30 & 55,722 & D30 & 55,704 & E30 & 55,610 \\
\hline B31 & 55,774 & C 31 & 55,720 & D31 & 55,687 & E31 & 55,608 \\
\hline B32 & 55,767 & $\mathrm{C} 32$ & 55,743 & D32 & 55,675 & E32 & 55,593 \\
\hline B33 & 55,789 & C33 & 55,741 & D33 & 55,667 & E33 & 55,559 \\
\hline B34 & 55,782 & C34 & 55,748 & D34 & 55,667 & E34 & 55,588 \\
\hline B35 & 55,796 & C35 & 55,762 & D35 & 55,664 & E35 & 55,590 \\
\hline B36 & 55,799 & C36 & 55,753 & D36 & 55,658 & E36 & 55,580 \\
\hline B 37 & 55,813 & C37 & 55,755 & D37 & 55,654 & E37 & $-\cdots-\cdots$ \\
\hline B38 & 55,813 & C38 & 55,750 & D38 & 55,653 & E38 & 55,595 \\
\hline B39 & 55,825 & C39 & 55,758 & D39 & 55,638 & E39 & 55,595 \\
\hline B40 & 55,841 & $\mathrm{C} 40$ & 55,763 & D40 & 55,623 & E40 & 55,566 \\
\hline B41 & 55,828 & $C 41$ & 55,767 & D41 & 55,624 & $E 41$ & 55,572 \\
\hline B42 & 55,830 & $\mathrm{C} 42$ & 55,763 & D42 & 55,621 & E42 & 55,562 \\
\hline B43 & 55,823 & $C 43$ & 55,782 & $D 43$ & 55,625 & 543 & 55,547 \\
\hline B44 & 55,824 & $\mathrm{C} 44$ & 55,786 & D44 & 55,627 & E44 & 55,575 \\
\hline B45 & 55,829 & $C 45$ & $\cdots \cdots$ & $D 45$ & 55,645 & E45 & 55,552 \\
\hline B46 & 55,836 & $C 46$ & 55,796 & D46 & 55,655 & $E 46$ & 55,575 \\
\hline B47 & 55,827 & $C 47$ & 55,802 & D47 & 55,682 & $\mathrm{E} 47$ & 55,570 \\
\hline B48 & 55,855 & C48 & 55,818 & D48 & 55,704 & E48 & 55,567 \\
\hline
\end{tabular}




\begin{tabular}{|c|c|c|c|c|c|c|c|}
\hline $\begin{array}{l}\text { Station } \\
\text { B49 }\end{array}$ & $\begin{array}{l}\text { Gammas } \\
55,870\end{array}$ & $\begin{array}{l}\text { Station } \\
\text { C49 }\end{array}$ & $\begin{array}{l}\text { Gammas } \\
55,831\end{array}$ & $\begin{array}{l}\text { Station } \\
\text { D49 }\end{array}$ & $\begin{array}{l}\text { Gammas } \\
55,714\end{array}$ & $\begin{array}{l}\text { Station } \\
\text { E49 }\end{array}$ & $\begin{array}{l}\text { Gammas } \\
55,570\end{array}$ \\
\hline B50 & 55,863 & $\mathrm{C} 50$ & 55,825 & D50 & 55,709 & E50 & 55,573 \\
\hline B5 1 & 55,835 & $\mathrm{C5} 1$ & 55,831 & D5 1 & 55,712 & E51 & 55,589 \\
\hline B52 & 55,850 & $\mathrm{C} 52$ & 55,840 & D52 & 55,718 & $E 52$ & 55,750 \\
\hline B53 & 55,859 & C53 & 55,854 & D53 & 55,706 & E53 & 55,750 \\
\hline B54 & 55,868 & $\mathrm{C} 54$ & 55,872 & D54 & 55,710 & E54 & 55,748 \\
\hline B 55 & 55,865 & $\mathrm{C} 55$ & 55,862 & D55 & 55,710 & E55 & 55,753 \\
\hline B56 & 55,865 & C56 & 55,879 & D56 & 55,707 & E56 & 55,756 \\
\hline B57 & 55,863 & $\mathrm{C} 57$ & 55,926 & D57 & 55,707 & E57 & 55,746 \\
\hline B58 & 55,860 & C58 & 55,903 & D58 & 55,689 & E58 & 55,760 \\
\hline B59 & 55,867 & C59 & 55,906 & D59 & 55,675 & E59 & 55,746 \\
\hline B60 & 55,865 & $\mathrm{C} 60$ & 55,895 & D60 & 55,674 & E60 & 55,746 \\
\hline B61 & 55,871 & C61 & 55,905 & D61 & 55,663 & E61 & 55,737 \\
\hline B62 & 55,864 & C62 & 55,921 & D62 & 55,659 & E62 & 55,744 \\
\hline B63 & 55,723 & C63 & 55,889 & D63 & 55,653 & E63 & 55,740 \\
\hline B64 & 55,732 & C64 & 55,888 & D64 & 55,646 & E64 & 55,695 \\
\hline 365 & 55,730 & C65 & 55,887 & D65 & 55,630 & E65 & 55,713 \\
\hline B66 & 55,733 & C66 & 55,873 & D66 & 55,617 & E66 & 55,707 \\
\hline B67 & 55,735 & C67 & 55,900 & D67 & 55,623 & E67 & 55,698 \\
\hline B68 & 55,734 & C68 & 55,911 & D68 & 55,635 & E68 & 55,702 \\
\hline B69 & 55,731 & C69 & 55,858 & D69 & 55,628 & E69 & 55,685 \\
\hline B 70 & 55,731 & $\mathrm{C} 70$ & 55,864 & D70 & 55,620 & E70 & 55,681 \\
\hline B71 & 55,734 & C71 & 55,889 & D71 & 55,620 & E71 & 55,669 \\
\hline B72 & 55,730 & C72 & 55,877 & D72 & 55,606 & E72 & 55,685 \\
\hline B73 & 55,734 & $\mathrm{C} 73$ & 55,883 & D73 & 55,606 & E73 & 55,681 \\
\hline B 74 & 55,736 & C74 & 55,871 & D74 & 55,608 & E74 & 55,633 \\
\hline B 75 & 55,737 & C75 & 55,875 & D75 & 55,588 & E75 & 55,641 \\
\hline B76 & 55,748 & $\mathrm{C} 76$ & 55,850 & D76 & 55,602 & E76 & 55,639 \\
\hline B77 & 55,733 & C77 & 55,856 & D77 & 55,593 & E77 & 55,628 \\
\hline B78 & 55,730 & $\mathrm{C} 78$ & 55,843 & D78 & 55,586 & E78 & 55,631 \\
\hline B 79 & 55,720 & C79 & 55,820 & D79 & 55,588 & $5 ; 9$ & 55,619 \\
\hline B80 & 55,724 & $\mathrm{C} 80$ & 55,789 & D80 & 55,567 & E80 & 55,600 \\
\hline B81 & 55,718 & C81 & 55,772 & D81 & 55,576 & E81 & 55,587 \\
\hline B82 & 55,734 & C82 & 55,855 & $\mathrm{D} 82$ & 55,571 & $E 82^{\circ}$ & 55,600 \\
\hline B83 & 55,711 & C83 & 55,841 & D83 & 55,559 & E83 & 55,587 \\
\hline B84 & 55,707 & C84 & 55,815 & D84 & 55,570 & E84 & --- \\
\hline B85 & 55,689 & $\mathrm{C} 85$ & 55,796 & D85 & 55,585 & E85 & 55,572 \\
\hline B86 & 55,690 & C86 & 55,797 & D86 & 55,595 & E86 & 55,569 \\
\hline B87 & 55,654 & & & D87 & 55,586 & E87 & 55,572 \\
\hline B88 & 55,659 & & & D88 & 55,612 & 588 & 55,537 \\
\hline B89 & $55 ; 648$ & & & D89 & 55,632 & E89 & 55,576 \\
\hline B90 & 55,620 & & & D90 & 55,641 & E90 & 55,577 \\
\hline B91 & 55,616 & & & D91 & 55,663 & & \\
\hline B92 & 55,602 & & & D92 & 55,667 & & \\
\hline B93 & 55,584 & & & D93 & 55,691 & & \\
\hline & & & & D94 & 55,696 & & \\
\hline & & & & D95 & 55,713 & & \\
\hline & & & & D96 & 55,709 & & \\
\hline & & & & D97 & 55,712 & & \\
\hline & & & & D98 & 55,720 & & \\
\hline & & & & D99 & 55,728 & & \\
\hline
\end{tabular}




$\begin{array}{ll}\text { Station } & \text { Gammas } \\ \text { D100 } & 55,750 \\ \text { D101 } & 55,744 \\ \text { D102 } & 55,751 \\ \text { D103 } & 55,755 \\ \text { D104 } & 55,756 \\ \text { D105 } & 55,754 \\ \text { D106 } & 55,753 \\ \text { D107 } & 55,760 \\ \text { D108 } & 55,762 \\ \text { D109 } & 55,744 \\ \text { D110 } & 55,743 \\ \text { D111 } & 55,763 \\ \text { D112 } & 55,759 \\ \text { D113 } & 55,761 \\ \text { D114 } & 55,774 \\ \text { D115 } & 55,775 \\ \text { D116 } & 55,794 \\ \text { D117 } & 55,800 \\ \text { D118 } & 55,814 \\ \text { D119 } & 55,833 \\ \text { D120 } & 55,849 \\ \text { D121 } & 55,856 \\ \text { D122 } & 55,872 \\ \text { D123 } & 55,884 \\ \text { D124 } & 55,875 \\ \text { D125 } & 55,878 \\ \text { D126 } & 55,879 \\ \text { D127 } & 55,887 \\ \text { D128 } & 55,873 \\ \text { D129 } & 55,883 \\ & \\ & \end{array}$




\begin{tabular}{|c|c|c|c|}
\hline $\begin{array}{l}\text { Station } \\
\text { F1 }\end{array}$ & $\begin{array}{c}\text { Gammas } \\
55,616\end{array}$ & $\begin{array}{l}\text { Station } \\
\text { Gl }\end{array}$ & $\begin{array}{l}\text { Gammas } \\
55,737\end{array}$ \\
\hline$F 2$ & 55,592 & G2 & 55,731 \\
\hline F3 & 55,597 & G3 & 55,708 \\
\hline F4 & 55,592 & G4 & 55,719 \\
\hline F5 & 55,588 & G5 & 55,733 \\
\hline F6 & 55,593 & G6 & 55,715 \\
\hline F7 & 55,576 & G7 & 55,729 \\
\hline F8 & 55,592 & G8 & 55,734 \\
\hline F9 & 55,608 & G9 & 55,725 \\
\hline F 10 & 55,621 & G10 & 55,734 \\
\hline Fll & 55,610 & G11 & 55,739 \\
\hline F 12 & 55,610 & G12 & 55,735 \\
\hline F 13 & 55,621 & G13 & 55,737 \\
\hline F14 & 55,627 & G14 & 55,750 \\
\hline F15 & 55,624 & G15 & 55,752 \\
\hline F16 & 55,614 & G16 & 55,756 \\
\hline F 17 & 55,627 & G17 & 55,753 \\
\hline F 18 & 55,635 & G18 & 55,764 \\
\hline F19 & 55,635 & G19 & 55,766 \\
\hline F 20 & 55,639 & $\mathrm{G} 20$ & 55,764 \\
\hline F21 & 55,615 & G21 & 55,761 \\
\hline F 22 & 55,632 & $\mathrm{G} 22$ & 55,758 \\
\hline F 23 & 55,622 & G23 & 55,756 \\
\hline F24 & 55,633 & G24 & 55,760 \\
\hline F 25 & 55,638 & G25 & 55,796 \\
\hline F26 & $----\infty$ & G26 & 55,784 \\
\hline F 27 & 55,630 & G27 & 55,788 \\
\hline F 28 & 55,638 & $\mathrm{G} 28$ & 55,790 \\
\hline F29 & 55,652 & G29 & 55,778 \\
\hline F30 & 55,658 & G30 & 55,783 \\
\hline F 31 & 55,658 & G31 & 55,753 \\
\hline F32 & 55,672 & G32 & 55,765 \\
\hline F33 & 55,663 & G33 & 55,764 \\
\hline F34 & 55,669 & G34 & 55,762 \\
\hline F35 & 55,682 & G35 & 55,764 \\
\hline F36 & 55,690 & G36 & 55,782 \\
\hline F37 & 55,695 & G37 & 55,784 \\
\hline F38 & 55,698 & G38 & 55,775 \\
\hline F39 & 55,697 & G39 & 55,782 \\
\hline F40 & 55,710 & G40 & 55,796 \\
\hline F41 & 55,708 & G41 & 55,792 \\
\hline F42 & 55,706 & G42 & 55,779 \\
\hline F43 & 55,705 & G43 & 55,780 \\
\hline F44 & 55,723 & G44 & 55,795 \\
\hline F45 & 55,712 & G45 & 55,782 \\
\hline F46 & 55,718 & G46 & 55,784 \\
\hline 547 & 55,719 & G47 & 55,789 \\
\hline
\end{tabular}




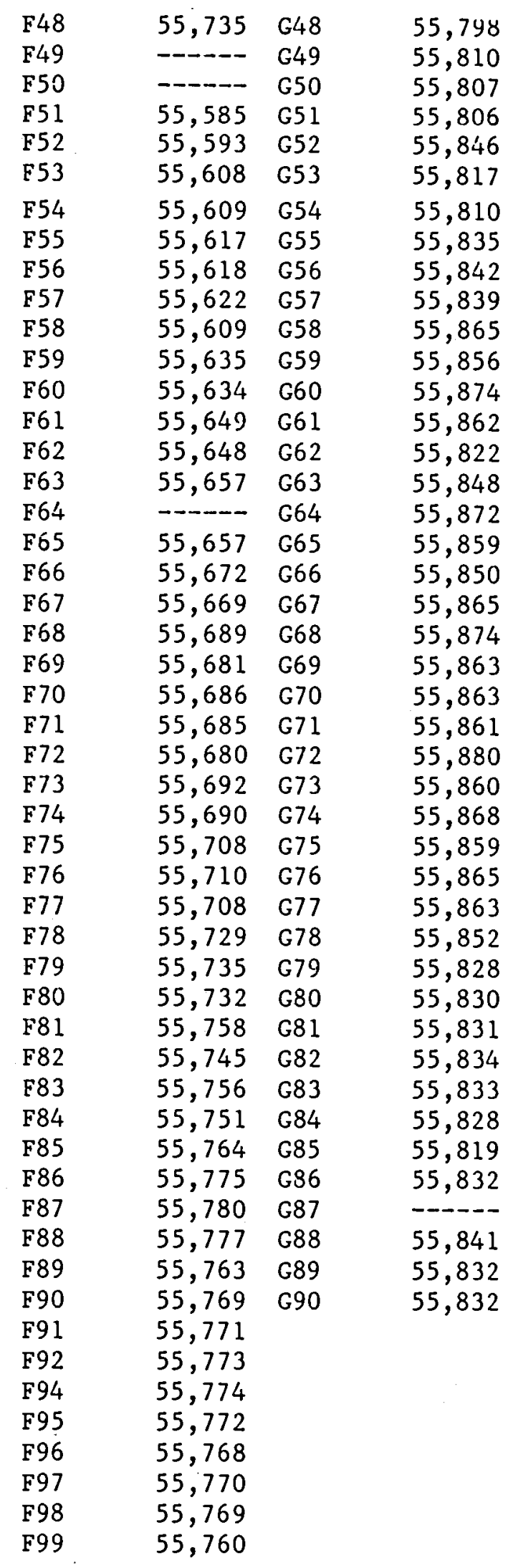


F100 55,754

F101 55,743

F 102

55,749

F103

55,742

F104 55,744

F105 55,741

F106 55,737 